\title{
¿Qué constituye la transición Paracas-Nasca en Paracas Necrópolis? Prácticas mortuorias, artefactos presentes, FORMAS DE INDUMENTARIA Y DIVERSIDAD SOCIOCULTURAL
}

Ann H. Peters

\begin{abstract}
Resumen
Para reevaluar la contribución del complejo mortuorio Paracas Necrópolis a la comprensión de la transición ParacasNasca, se traza la distribución de artefactos textiles y no textiles en una muestra de contextos relativamente bien documentados. La evidencia procedente de fardos complejos y más simples permite proponer un modelo del orden social, las relaciones de intercambio y los procesos históricos. Sobre la base de la reconstrucción de cada contexto mortuorio, la distribución de los tipos de artefactos, las asociaciones de género y las secuencias de prácticas mortuorias se aporta mejor evidencia para evaluar el rango social y los roles rituales. Los tipos y estilos de artefactos se agrupan de acuerdo a su presencia en los mismos contextos mortuorios para evaluar la cronología Paracas-Nasca de la escuela de Berkeley y las correlaciones de Dwyer y Paul para los textiles de Paracas Necrópolis. Tener en cuenta la agencia de quienes atendieron a los muertos, los productores y usuarios de los objetos presentes y sus relaciones de intercambio es esencial para caracterizar las tradiciones de cultura material y los procesos históricos de interacción en un mundo social complejo.
\end{abstract}

Palabras clave: arqueología mortuoria, textiles, vestimenta, género, Wari Kayan, Paracas, Topará, Nasca

\section{Abstract \\ WHAT CONSTITUTE THE PARACAS-NASCA TRANSITION IN PARACAS NECROPOLIS? MORTUARY PRACTICES, ARTIFACTS, PRESENT, GARMENT FORMAS AND SOCIOCULTURAL DIVERSITY}

To evaluate the contribution that the Paracas Necropolis mortuary complex makes to our understanding of the Paracas-Nasca transition, the distribution of textile and non-textile artifacts is tracked among a sample of relatively well-documented gravelots. Evidence from complex and simpler burials informs a model of the social order, exchange relationships and historic processes. Based on the reconstruction of each mortuary context, the distribution of artifact types, gender associations and sequences of mortuary practice provide better evidence to evaluate social rank and ritual roles. Artifact types and styles are grouped based on their co-occurrence in mortuary contexts to evaluate the Berkeley School Paracas-Nasca chronology and Dwyer-Paul correlations for Paracas Necropolis textiles. Awareness of the agency of those who attended to the dead, the producers and users of the objects present and their exchange relationships is essential for characterizing material culture traditions and historic processes of interaction in a complex social world.

Keywords: Mortuary archaeology, textiles, dress, gender, Wari Kayan, Paracas, Topará, Nasca

\footnotetext{
${ }^{a}$ Consulting Scholar, American Section

University of Pennsylvania Museum of Archaeology and Anthropology

Correo electrónico: ann.h.peters@gmail.com
} 


\section{Introducción}

El análisis de la dinámica histórico-social de la época de transición entre los complejos de cultura material denominados "Paracas Tardío» (Tello 1929, 1930, 1959; O’Neale 1932, 1942; Kroeber 1953; Menzel, Rowe y Dawson 1964; King 1965; Dwyer 1979; Tello y Mejía 1979; Paul 1982, 1990; Kauffman 1999) y los denominados «Nasca» o «Nazca Temprano» (Uhle 1914; Tello 1930, 1959; O’Neale 1937, Proulx 1968, 2006; Sawyer 1961, 1979, 1997; Frame 1999), ha sido complicado debido a la asociación de grupos estilísticos con fases temporales, lo cual fue producto del uso de las teorías y métodos de análisis del cambio estilístico, buscando establecer secuencias temporales antes del desarrollo de otras técnicas de datación. Aunque se hayan reconocido los dos ejes de distribución, geográfica y temporal, en la metodología de la Escuela de Berkeley, el uso de «fase» como categoría de grupo estilístico, no ha facilitado el análisis de la variabilidad formal como marcador de diferenciación social, sea a propósito en un estilo comunicativo, o un estilo emblemático de un grupo social (Wobst 1977), o como resultado de los materiales y procesos específicos manejados por diferentes comunidades de producción (Sackett 1990).

La tradición Paracas ha sido definida sobre la base de combinar la incisión y la pintura poscocción en la cerámica, junto a otras técnicas como los diseños en técnica negativa y el modelado. La cerámica Topará que acompaña a los fardos de Wari Kayan no se caracteriza por estas técnicas y más bien se distingue por otros alfares, formas y técnicas de modelado, grabado de la superficie y manipulación de la cocción. Las dos tradiciones aparecen juntas en ciertas tumbas de Ocucaje fase $10 \mathrm{~A}$ y se fusionan en ciertas formas definidas como Ocucaje $10 \mathrm{~B}$ y Nasca 1 . Se considera que las fases Ocucaje 9 y 10, así como Nasca 1 y 2 definidas en el valle de Ica, no constituyen parte del Horizonte Temprano según su definición original, por ser subsecuentes a la esfera de interacción de Chavín. Estos estilos corresponden un nuevo orden social, el cual es a la vez formativo y transicional, un período de desarrollo de nuevas pautas discursivas de mitología y liderazgo social, las que son después manipuladas por el orden político entre señoríos regionales, a las cuales denominamos Nasca. El rito mortuorio y ancestral que se denomina Paracas Necrópolis ha jugado un papel central en esta transición en la costa sur-central, y el período que abarca estos entierros lo define cronológicamente.

La tradición mortuoria de Paracas Necropolis, fue definida por Julio C. Tello en las excavaciones de 1927-1928, principalmente por las zonas de cementerio de las Necrópolis de Wari Kayan en el sitio de Paracas (Tello 1929, 1959; Tello y Mejía 1979). También hay contextos cercanos en los sectores de Cerro Colorado y Arena Blanca, que corresponden a las mismas prácticas mortuorias y estilos de artefactos presentes. Para tomar en consideración tanto la presencia de grupos sociales diversos en el mundo de quienes formaron y enterraron los fardos mortuorios de Paracas Necrópolis, como los cambios en ese mundo a través del tiempo de formación de estos cementerios, ordenamos la gran diversidad de artefactos de estos contextos mortuorios en grupos definidos a partir de un conjunto de características formales y técnicas, para luego trazar la incidencia de artefactos de estos grupos en cada fardo (Tablas 2 a 11).

Los tipos de objetos y rasgos de estilo característicos de cada grupo, muestran una alta incidencia de coocurrencia en ciertos contextos mortuorios. Sin embargo, la similitud y la deposición final compartida no implica que todos los artefactos de un grupo estilístico hayan sido creados por un mismo «taller» o grupo social, porque existen diferencias más específicas a nivel de procesos de producción, diseño e iconografía que indican que artefactos parecidos son productos de diferentes manos. Entonces, la variabilidad formal se considera tanto un producto de diferencias entre sus productores como diferencias temporales. A través de la caracterización de los grupos, se busca arrojar luz a la relación entre las formas de bienes materiales, las identidades y relaciones sociales y los cambios a través de un proceso histórico dinámico.

Al identificar los tipos de artefactos y estilos recurrentes que dominan en cierto contexto mortuorio, se propone que este conjunto representa aspectos centrales de la identidad sociocultural, tanto del individuo como de las personas a cargo de las atenciones postmortem. También se puede 
identificar artefactos novedosos y estilos minoritarios que aparecen en este contexto, que se propone representar una red social más amplia. Se puede trazar la distribución de cada tipo de artefacto y estilo en los otros contextos registrados de Paracas Necrópolis y según los datos disponibles, donde han sido registrados en otros sectores del sitio de Paracas y en otros sitios de la región. Finalmente, se puede caracterizar el grupo de fardos cuya construcción y artefactos caracterizan una fase, $\mathrm{o}$ abarcan varias fases de la formación del cementerio.

La gran mayoría de los fardos mortuorios de Paracas Necrópolis son pequeños, del tamaño del individuo sentado en su interior, aproximadamente. Sin embargo, muchos de estos fardos identificados como categoría "Z» cuando fueron excavados, suelen conservar los restos de un hermoso tocado, uno o dos mantos, otras indumentarias y otros artefactos. Aproximadamente $8 \%$ de los fardos son mucho más complejos y de mayor tamaño, en los cuales se ha registrado entre 30 y más de 200 objetos diferentes, con una mayor diversidad formal, por lo cual, han sido caracterizados como personajes de alto rango. Pero, ¿̨cuál es la relación entre la acumulación de bienes en la tumba y el rol y poder social en vida? Para caracterizar a los personajes de Paracas Necrópolis y su relación con el mundo social, marcado por las tradiciones de cerámica Topará (Wallace 1986; Peters 1997), Paracas Tardío y Nasca Inicial, hay que mirar de cerca el contenido de cada tumba, las evidencias de la procedencia de cada objeto y los procesos de formación del fardo mortuorio.

La interpretación de la presencia de los diversos componentes de cada ajuar mortuorio se basa en un modelo de intercambio entre actores sociales, en el cual el liderazgo social se fundamenta en el desarrollo de relaciones diversas de alianza y confrontación, esenciales al manejo de poder económico (Mauss 1990 [1923-1924]; Godelier 1998). Se considera que gran parte del significado de un objeto al añadirlo al fardo ha sido para indicar (Gell 1998) una serie de eventos y relaciones que forman parte de la historia de su creación, uso y manipulación. Los objetos de cada contexto mortuorio y especialmente la indumentaria incorporada al fardo, serán entonces, resultados e indicadores de actos de intercambio, que pueden haberse realizado durante la vida del individuo, o por otras personas como parte de la preparación para ofrendar al antecesor fallecido, lo que puede ocurrir en varios eventos posteriores.

Considero que la capacidad de movilizarse en el paisaje andino, acceder a diversos recursos y producir los bienes que constituyen riqueza y poder social, se basa en establecer y mantener relaciones de intercambio, tanto bélicas como amistosas. En este principio se basa un modelo de diferenciación de rango social, expresado en las prácticas mortuorias. Este modelo no está necesariamente relacionado a los mecanismos asociados al desarrollo de un Estado, sino a alianzas sociales análogas a las documentadas históricamente para los curacas andinos a nivel local y regional, líderes de grupos corporativos de costa y sierra definidos por un discurso y práctica de parentesco, que operaba en varias escalas. Sus interacciones en la política y economía regional bajo los estados Inka y colonial han sido documentadas por diversos investigadores (v.g. Rostwororski 1983; Zuidema 1990; Duviols 2003). Se considera que estas formas de liderazgo y su relación a la importancia política de mantener relaciones con seres ancestrales en actos públicos, y la construcción de monumentos mortuorios en piedra (Isbell 1997), o el mismo fardo textil (Deleonardis y Lau 2004), fueron centrales en la reproducción —y la evolución — del orden social, a través de la larga historia de las sociedades complejas en los Andes centrales y sur-centrales.

El estudio de la estructura de los fardos aporta datos relevantes para un análisis de su temporalidad y, a la vez, aporta datos sobre las prácticas que crearon la diferenciación evidente en los tamaños de los fardos y en los artefactos contenidos (Thays 2016). El nuevo análisis de la documentación producida en la abertura de los fardos, junto al estudio de la forma y condición de cada artefacto, establece que el fardo suele representar no un solo proceso funerario, sino una serie de eventos luego de la muerte del individuo. En el caso de los fardos más simples, la preparación del cuerpo en una posición sentada con la cara tapada con fibra de algodón y cubierta por una tela recién tejida, colocar fragmentos y adornos de láminas de oro, poner un cuenco de mate en las rodillas y la envoltura en una tela grande tejida de algodón, juntos, constituyen un solo evento. 
Pero para los fardos con varias capas de envolturas, en la mayoría de casos que han sido estudiados, la creación y el arreglo de cada capa de vestido constituyen evidencia de un evento particular, la conversión de la persona fallecida en un personaje ancestral y la evolución posterior de su rol social.

Los textiles bordados y otros artefactos conservados en una capa del fardo se encontraban a veces doblados, o más frecuentemente envolviendo el fardo cónico, o arreglados en el mońo o «falsa cabeza» como un tocado. Por lo mismo, las capas de vestimenta para la exposición del fardo ancestral se interpretan como uno o más eventos de ritos, y en alguna medida «públicos». En muchos casos se puede distinguir varias capas de vestimenta inmediatamente sobrepuestas y no queda claro si estas indumentarias sucesivas representan o no diferentes eventos. En otros casos, la ubicación de un elemento de un juego de indumentarias (típicamente el manto) en una capa externa, sugiere que se practicaba la sustracción y la reposición de objetos como parte de las atenciones al fardo. La superposición de varias capas de envolturas con niveles cosidos y amarrados en una «falsa cabeza», pero sin adornos presentes, sugiere también que una capa de vestimenta posiblemente haya sido desmantelada. No se puede descartar la posibilidad de que algunos objetos hayan sido extraídos de un fardo, o reubicados desde otro fardo. Por este motivo, empleamos el método de la Matriz de Harris para notar evidencias de secuencia y calcular un terminus post quem para cada capa del fardo y luego para su entierro en el lugar, con los objetos asociados, registrados en las excavaciones arqueológicas.

Por lo tanto, nuestra definición del rango social expresado en el contexto mortuorio se basa en tres factores: 1) la estructura del fardo y en particular la evidencia del número de capas de exposición que necesariamente fueron construidas en eventos distintos; 2) la cantidad y calidad de los artefactos que han sido identificados; y 3 ) la diversidad de los estilos presentes.

\section{La muestra}

En 2001, se presentó el reto de colaborar en la recontextualización de Paracas Necrópolis, en respuesta a una iniciativa desarrollada por la dirección y los curadores del Museo Nacional de Arqueología, Antropología e Historia del Perú (MNAAHP). El Proyecto «Prácticas en vida, presencia después de la muerte: lo estilístico y lo material en Paracas Necrópolis», se propuso mejorar los datos disponibles a través de la documentación de contextos mortuorios no publicados, el estudio de artefactos no representados en las publicaciones y el análisis de rasgos no notados en los registros anteriores. Entre 2006 y 2012 se realizó el reestudio de los restos humanos y los artefactos recuperados y conservados de 16 contextos. La mitad corresponde a fardos mortuorios custodiados por museos fuera de Lima, enviados a EEUU en 1937 (WK 16 a PMEA; WK 113, WK 114 y WK 188 al AMNH), Ica y Cusco en 1951 (WK 136 y WK 352 al MRI; WK 375 al UNSAAC) y 1959 a Cusco (WK 27 al UNSAAC). La muestra del MNAAHP consiste en ocho contextos que fueron estudiados por un equipo bioantropológico dirigido por Elsa Tomasto-Cagigao y un equipo de arqueólogos dirigido por Ann H. Peters y Carmen Carranza. Estos contextos son AB 4, WK 23, WK 24, WK 26, WK 28, WK 199, WK 364 y WK 381. Con la colaboración de colegas de diferentes especialidades, se realizó la documentación de aquellos artefactos asociados que se pudieron ubicar en 2011-2012 en los catálogos y depósitos del MNAAHP.

Este grupo de contextos analizados en detalle ha sido comparado con una muestra más amplia de objetos asociados a contextos mortuorios complejos estudiados o abiertos debido a su condición, bajo la dirección de Julio C. Tello (1927-1945) y una muestra de 60 fardos del extremo oriental del Sector A y varios de Arena Blanca, abiertos bajo la dirección de Toribio Mejía en 1968-1970. Es importante resaltar los seis contextos femeninos estudiados en 1933, 1938-9 y 1975, por la documentación de indumentaria femenina, lo cual es importante para comparar con los dos fardos femeninos en nuestra muestra. Los textos de los protocolos de disección de la mayoría de los fardos abiertos entre 1928 y 1945, con diagramas y fotografías, han sido conservados en el Archivo Tello 

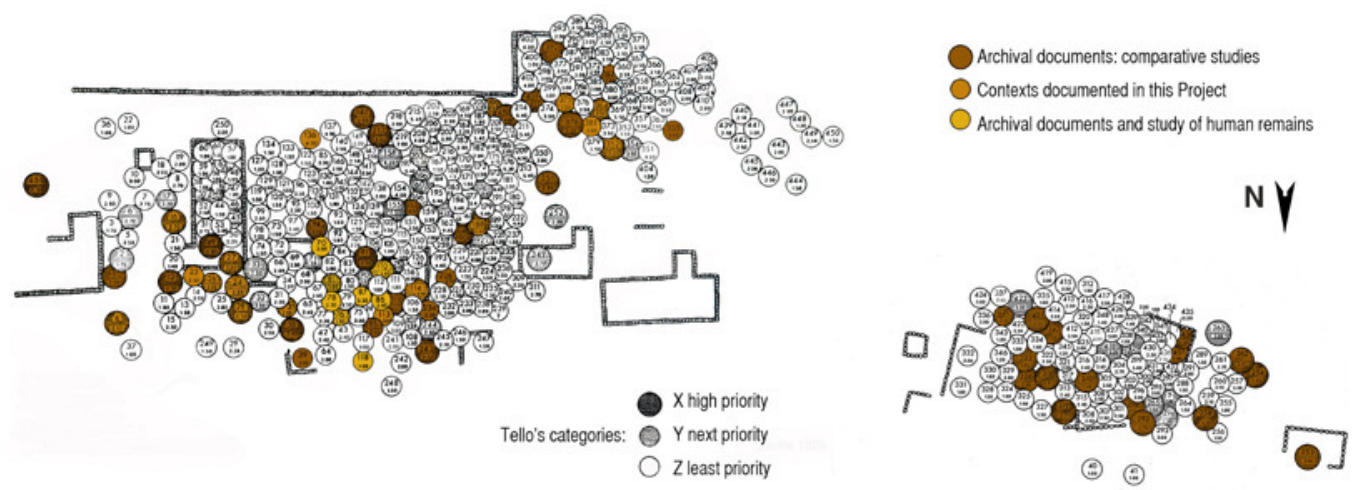

Figura 1. El cementerio de Wari Kayan, Sectores A y B, con la distribución de los contextos reanalizados y la muestra comparativa (A. H. Peters, incorporando datos procedentes de Paul 1990; Tello y Mejía 1979).

del Museo de Arqueología y Antropología de la Universidad Nacional Mayor de San Marcos (Tello et al. 2012), resumidos en la base de datos del proyecto (www.arqueologia-paracas.net).

Los contextos del grupo reanalizado provienen del Sector A de Wari Kayán. En la Figura 1 se nota la distribución espacial de estos contextos y de la muestra comparativa. Mientras fue posible identificar asociaciones de estilo entre algunos contextos mortuorios adyacentes, estos mismos se encuentran al lado de otros con características muy distintas y de fases diferentes según las propuestas de Dwyer (1979) y Paul (1990). A la vez, hemos podido trazar relaciones de estilo muy cercanas entre contextos procedentes de todos los cuadrantes de ambos sectores de las Necrópolis de Wari Kayan y los contextos correspondientes al patrón mortuorio Paracas Necrópolis ubicados en cateos cercanos y en el sector de Arena Blanca.

Los individuos en la muestra reestudiada son adultos de edad media o adultos mayores (35-50 años). El sexo se basa en características físicas ligadas a criterios biológicos (Buikstra y Ubelaker 1994), mientras el género se basa en los artefactos asociados. El rango (X-Y-Z) designado por Tello en el inventario de excavación expresa sus prioridades de investigación posterior. El número de capas de exposición suma niveles de envoltura textil con prendas, tocados y otros artefactos que se encontraron separados por otras capas de envolturas de tela de algodón, selladas por una tela en forma de bolsa cosida y amarrada en forma de un moño o falsa cabeza. Este representa un número mínimo de eventos en los que el fardo ha sido refaccionado. En los fardos complejos son comunes las secuencias de varias envolturas, con más de un nivel de cosido, o hay dos o más capas de un conjunto de prendas con un tocado, directamente superpuestas. La primera capa de exposición consiste en el tocado, los ornamentos de concha y metal, y otros objetos asociados directamente al individuo. Cada capa subsecuente reúne ofrendas dobladas y las que «visten» el fardo.

Para evaluar la complejidad de cada fardo, el número de artefactos y otros objetos citados se basa en aquellos identificados o confirmados en el reestudio. En varios fardos este número excede los de la lista del inventario inicial, mientras en otros casos, fragmentos inicialmente enumerados individualmente, han sido luego identificados como parte de un solo artefacto. El número total de prendas y tocados incluye la indumentaria simple y decorada, bandas y cuerdas complejas, bolsas y adornos plumarios. Los penachos cosidos a una banda de tocado se consideran un componente del mismo artefacto, pero los penachos y borlas con una estructura independiente se cuentan aparte, tanto como las redes, telitas plumadas e indumentaria en miniatura. Otros tipos de artefactos presentes son contenedores, armas e implementos diversos que se presentan en la discusión de cada fase estilística como potenciales indicadores de género, rango y grupo social.

Los objetos externos al fardo mortuorio pueden incluir una o dos esteras, diversos recipientes de cerámica, cestería, mates (Lagenaria sp.), cañas, varas, bastones y otras armas e implementos. 
Como la mayoría de las tumbas son fosas simples rellenadas con arena limpia o arena con materiales procedentes de las capas ocupacionales, las asociaciones de cada contexto se basan en la ubicación de los objetos y el carácter de los rellenos notados en la excavación (Tello y Mejía 1979; Tello et al. 2012). La gran mayoría de los fardos y los individuos dentro de ellos se hallaron sentados con la cara hacia el norte, con los recipientes en ese lado de la base, y la cańa o las armas al lado derecho (al este) o en ambos lados. Restos de la estera protectora tapaban la cima de los fardos grandes y de algunos fardos más pequeños. La identificación de los tipos y cantidades de ofrendas de alimentos varía en las notas e inventario de excavación y según su registro y posterior conservación, por esto, se calculan aquí los alimentos como una sola ofrenda.

Finalmente, es importante tener en cuenta que la mayoría de los fardos se encontraron deteriorados en su base. Hay abundante evidencia de movimiento de objetos del exterior al fondo del fardo, donde fueron registrados junto a los restos humanos. Esta situación ha sido comentada en las excavaciones de 1927-1928 y tomando en consideración la evidencia de movimiento y renovación de los fardos en su historia anterior, también pueden haber ocurrido pérdidas o adiciones en aquellas ocasiones. Es especialmente frecuente encontrar en el fardo huesos del pie de otro individuo, o fragmentos de contenedores y alimentos. Los casos de entierros secundarios, donde un fardo ha sido creado con paquetes que contienen los restos completos o incompletos de varios individuos, también indican desigualdades en la condición y el trato de los fardos originales.

La Tabla 1 presenta un resumen del contenido de los contextos analizados en 2010-2012, junto a los contextos relativamente bien documentados que forman la muestra comparativa. Los contextos se dividen en grupos que comparten textiles de los mismos estilos. La mayoría de los fardos complejos incluyen artefactos diagnósticos de dos o más fases estilísticas, según los criterios de Dwyer (1979) y Paul (1990). En la reevaluación, los artefactos se agruparon según los estilos predominantes, considerando que los artefactos excepcionales pueden incluir un objeto guardado o transferido desde otro contexto, un objeto procedente de otro grupo social cuyas prácticas han sido clasificadas como Paracas o Nasca, o un objeto producto de eventos posteriores al proceso de crear el fardo. La mayoría de nuestros resultados confirman la secuencia cronológica de Paul (1990: 60). En el caso de los contextos femeninos, la mayoría de los artefactos asociados difieren de los tipos de prendas y estilos clasificados por Dwyer y Paul (Peters y Tomasto-Cagigao 2017). Los fardos femeninos se designan a las fases 10 y 1 por la presencia de elementos diagnósticos o artefactos compartidos con los fardos masculinos.

En los cuadernos de excavación, las categorías de rango se basan en: (1) el tamaño del fardo, (2) la presencia de textiles decorados y otros objetos visibles en aberturas en la envoltura exterior y (3) un conjunto de artefactos interesantes conservados junto al fardo. Al inicio de cada etapa del trabajo de campo, y en los momentos cuando los arqueólogos trabajaban en mejores condiciones, se ha designado una mayor cantidad de fardos ' $\mathrm{X}$ ' o ' $\mathrm{Y}$ '. Los rangos aquí propuestos se basan en 1) la estructura de cada fardo, especialmente la evidencia de eventos diferentes en la construcción de las capas de exposición; 2) la cantidad de artefactos finamente elaborados que han sido identificados y; (3) la diversidad en los estilos de artefactos presentes. Estos tres factores tienden a coincidir.

Los contextos reestudiados hasta la fecha no incluyen entierros «simples» de adultos, en los cuales no se identificaron textiles decorados. Aquí inciden factores de conservación, pero dentro de este grupo se define un cuarto rango social basado en el trato mortuorio. Todos los contextos de individuos juveniles y adolescentes registrados corresponden a este cuarto rango social, en el cual no hay evidencia de atenciones al fardo, posteriores al proceso funerario inicial. Pueden conservar sin embargo evidencia del mismo trato formal y ofrendas iniciales y en particular elementos de un tocado y fragmentos de adornos laminares de oro, y estar asociados a entre cero y siete objetos externos colocados en el momento del entierro. Los fardos mortuorios de adultos jóvenes registrados $\mathrm{y}$ de algunos adultos mayores corresponden al cuarto rango o en otros casos al tercer rango, en el cual se ha construido una falsa cabeza y se ha vestido el fardo en por lo menos un evento posterior. 
Tabla 1. Evidencia de rango social en los contextos analizados en detalle

Contextos mortuorios masculinos dominados por artefactos designados como 'fase 10A'

\begin{tabular}{ccccccccccc}
\hline Contexto & Sexo & Género & $\begin{array}{c}\text { Rango } \\
\text { (Tello) }\end{array}$ & $\begin{array}{c}\text { Capas } \\
\text { Expo. }\end{array}$ & $\begin{array}{c}\text { Telas } \\
\text { gruesas }\end{array}$ & $\begin{array}{c}\text { Prendas, } \\
\text { tocados }\end{array}$ & $\begin{array}{c}\text { Otros } \\
\text { artefactos }\end{array}$ & $\begin{array}{c}\text { Objetos } \\
\text { externos }\end{array}$ & $\begin{array}{c}\text { Rango } \\
\text { (Peters) }\end{array}$ \\
\hline WK 136 & M & M & Z & 3 & 3 & 11 & 11 & 7 & $3^{\circ}$ \\
WK 199 & M & M & Y & 4 & 6 & 17 & 31 & 7 & $2^{\circ}$ \\
WK 114 & M & M & Y & 7 & 15 & 51 & 36 & 4 & $1^{\circ}$ \\
WK 381 & M & M & Z & 2 & 3 & 7 & 10 & 3 & $3^{\circ}$ \\
\hline
\end{tabular}

Los contextos de la muestra comparativa incluyen Cat99t2, WK 147, WK 157.

Contextos mortuorios femeninos dominados por artefactos designados como 'fase 10'

\begin{tabular}{cccccccccc}
\hline Contexto & Sexo & Género & $\begin{array}{c}\text { Rango } \\
\text { (Tello) }\end{array}$ & $\begin{array}{c}\text { Capas } \\
\text { Expo. }\end{array}$ & $\begin{array}{c}\text { Telas } \\
\text { gruesas }\end{array}$ & $\begin{array}{c}\text { Prendas, } \\
\text { tocados }\end{array}$ & $\begin{array}{c}\text { Otros } \\
\text { artefactos }\end{array}$ & $\begin{array}{c}\text { Objetos } \\
\text { externos }\end{array}$ & $\begin{array}{c}\text { Rango } \\
\text { (Peters) }\end{array}$ \\
\hline WK 113 & F & F & Z & 2 & 3 & 6 & 12 & 5 & $3^{\circ}$ \\
\hline
\end{tabular}

Los contextos de la muestra comparativa incluyen WK 81, WK 86, WK 149, WK 437.

Contextos mortuorios masculinos dominados por artefactos designados como 'fase 10B'

\begin{tabular}{ccccccccccc}
\hline Contexto & Sexo & Género & $\begin{array}{c}\text { Rango } \\
\text { (Tello) }\end{array}$ & $\begin{array}{c}\text { Capas } \\
\text { Expo. }\end{array}$ & $\begin{array}{c}\text { Telas } \\
\text { gruesas }\end{array}$ & $\begin{array}{c}\text { Prendas, } \\
\text { tocados }\end{array}$ & $\begin{array}{c}\text { Otros } \\
\text { artefactos }\end{array}$ & $\begin{array}{c}\text { Objetos } \\
\text { externos }\end{array}$ & $\begin{array}{c}\text { Rango } \\
\text { (Peters) }\end{array}$ \\
\hline WK 352 & M & M-F & X & 3 & 16 & 45 & 20 & 3 & $2^{\circ}$ \\
WK 375 & M & M & Y & 2 & 5 & 10 & 4 & 7 & $3^{\circ}$ \\
\hline
\end{tabular}

Los contextos de la muestra comparativa incluyen WK 35, WK 49, WK 94, WK 157.

Contextos mortuorios masculinos dominados por artefactos designados como 'fase $1 \mathrm{~A}$ '

\begin{tabular}{cccccccccc}
\hline Contexto & Sexo & Género & $\begin{array}{c}\text { Rango } \\
\text { (Tello) }\end{array}$ & $\begin{array}{c}\text { Capas } \\
\text { Expo. }\end{array}$ & $\begin{array}{c}\text { Telas } \\
\text { gruesas }\end{array}$ & $\begin{array}{c}\text { Prendas, } \\
\text { tocados }\end{array}$ & $\begin{array}{c}\text { Otros } \\
\text { artefactos }\end{array}$ & $\begin{array}{c}\text { Objetos } \\
\text { externos }\end{array}$ & $\begin{array}{c}\text { Rango } \\
\text { (Peters) }\end{array}$ \\
\hline WK 24 & M & M & Y & 3 & 3 & 15 & 6 & 3 & $3^{\circ}$ \\
WK 26 & M & M & Y & 3 & 2 & 23 & 9 & 11 & $2^{\circ}$ \\
WK 16 & M & M & X & 4 & 10 & 46 & 36 & 4 & $2^{\circ}$ \\
WK 364 & M & M & X & 4 & 13 & 12 o 14 & 4 & 5 & $2^{\circ}$ \\
\hline
\end{tabular}

Los contextos de la muestra comparativa incluyen WK 49, WK 91, WK 94, WK 157, WK 217, WK 243, WK 292 (fardo 190), WK 420, WK 421, WK 438.

Contextos mortuorios femeninos dominados por artefactos designados como 'fase 1'

\begin{tabular}{ccccccccccc}
\hline Contexto & Sexo & Género & $\begin{array}{c}\text { Rango } \\
\text { (Tello) }\end{array}$ & $\begin{array}{c}\text { Capas } \\
\text { Expo. }\end{array}$ & $\begin{array}{c}\text { Telas } \\
\text { gruesas }\end{array}$ & $\begin{array}{c}\text { Prendas, } \\
\text { tocados }\end{array}$ & $\begin{array}{c}\text { Otros } \\
\text { artefactos }\end{array}$ & $\begin{array}{c}\text { Objetos } \\
\text { externos }\end{array}$ & $\begin{array}{c}\text { Rango } \\
\text { (Peters) }\end{array}$ \\
\hline WK 28 & F & F & $\mathrm{X}$ & 4 & 10 & 18 & 9 & 4 & $2^{\circ}$
\end{tabular}

Los contextos de la muestra comparativa incluyen WK 1, WK 234, WK 326, WK 347, WK 382 (fardo 12), WK 226.

Contextos mortuorios dominados por artefactos designados como 'fase 1B'

\begin{tabular}{cccccccccc}
\hline Contexto & Sexo & Género & $\begin{array}{c}\text { Rango } \\
\text { (Tello) }\end{array}$ & $\begin{array}{c}\text { Capas } \\
\text { Expo. }\end{array}$ & $\begin{array}{c}\text { Telas } \\
\text { gruesas }\end{array}$ & $\begin{array}{c}\text { Prendas, } \\
\text { tocados }\end{array}$ & $\begin{array}{c}\text { Otros } \\
\text { artefactos }\end{array}$ & $\begin{array}{c}\text { Objetos } \\
\text { externos }\end{array}$ & $\begin{array}{c}\text { Rango } \\
\text { (Peters) }\end{array}$ \\
\hline WK 27 & M & M & $\mathrm{X}$ & 3 & 5 & 18 & 4 & 5 & $2^{\circ}$ \\
WK 188 & M & M & $\mathrm{X}$ & 3 & 6 & 10 & 11 & $1+$ & $2^{\circ}$ \\
\hline
\end{tabular}

Los contextos de la muestra comparativa incluyen WK 12 (fardo 382), WK 38, WK 89, WK 190 (fardo 290), WK 262, WK 310, WK 378, WK 451.

Contextos mortuorios con la presencia de artefactos designados como 'fase 1B' y 'fase 2'

\begin{tabular}{cccccccccc}
\hline Contexto & Sexo & Género & $\begin{array}{c}\text { Rango } \\
\text { (Tello) }\end{array}$ & $\begin{array}{c}\text { Capas } \\
\text { Expo. }\end{array}$ & $\begin{array}{c}\text { Telas } \\
\text { gruesas }\end{array}$ & $\begin{array}{c}\text { Prendas, } \\
\text { tocados }\end{array}$ & $\begin{array}{c}\text { Otros arte- } \\
\text { factos }\end{array}$ & $\begin{array}{c}\text { Objetos } \\
\text { externos }\end{array}$ & $\begin{array}{c}\text { Rango } \\
\text { (Peters) }\end{array}$ \\
\hline WK 4 & M & M & X & 2 & 2 & 29 & 9 & 7 & $2^{\circ}$ \\
WK 23 & M & M & Z & 2 & 3 & 6 & 5 & 5 & $3^{\circ}$ \\
\hline
\end{tabular}

Los contextos de la muestra comparativa incluyen WK 38, WK 253, WK 298, WK 318, WK 319. 
En la muestra estudiada aparece un número relativamente grande de contextos relacionados al Horizonte Temprano 10, en contraste con los contextos relacionados predominantemente a Nasca, que han sido publicados por Tello (1959), Tello y Mejía (1979), Paul (1990, 1991b) y Aponte (2006). Esta muestra corresponde aproximadamente a las proporciones de los estilos asociados a los contextos sin publicar documentados en los protocolos de abertura. La predominancia de objetos publicados de los contextos designados como Intermedio Temprano 1A, 1B y 2, probablemente resulta del interés en estos estilos textiles para las exhibiciones museográficas del inicio del siglo XX, y por lo mismo no refleja las proporciones de estilos, afiliación social o distribución temporal en la población del cementerio.

La designación del rango basado en la estructura del fardo y la cantidad y diversidad de los artefactos presentes, es condicionada por las características desiguales de su conservación. El nivel de deterioro de cada fardo en el momento de su desenvoltura y estudio inicial afecta la observación de su estructura, y de la secuencia y características de los tipos de artefactos y estilos presentes. En el "protocolo de disección" del fardo, la numeración final de los artefactos suele depender de largos procesos de limpieza y separación posteriores al proceso de abertura inicial. La forma de ciertos artefactos textiles se reconstruye en base a pequeños fragmentos. Sin embargo, la reconstrucción de la secuencia del fardo, la cantidad de textiles elaborados y otros tipos de objetos presentes, y la diversidad estilística, tienden a coincidir en la propuesta del rango social. En contraste, el número y la calidad de los objetos externos al fardo frecuentemente no se correlacionan con la complejidad del fardo. Esta falta de correspondencia indica una diferencia entre el resultado cumulativo de los eventos anteriores que crearon la estructura y contenido del fardo mortuorio, y las circunstancias y significado social de los artefactos colocados en el evento de su entierro final.

El reanálisis de cada contexto permite definir con mayor claridad las formas de vestimenta y estilos decorativos que caracterizan cada fase temporal en la transición Paracas-Nasca. Se presenta aquí una tipología de formas de vestimenta, que se agrupan en sistemas de indumentaria asociados con ciertas técnicas y estilos decorativos. A través del análisis formal de las prendas y los tocados, se percibe la llegada sucesiva de nuevos grupos socioculturales, que han contribuido con trajes emblemáticos de sus diversas identidades. Además, aparecen nuevas formas de armas e instrumentos, mientras desaparecen algunos tipos de objetos que antes se colocaban en las tumbas, indicando cambios en las prácticas bélicas, la caza y la pesca, además de diferencias en la música y en las prácticas rituales (Peters y Tomasto-Cagigao 2017).

\section{Contextos asociados a una interacción con la tradición Paracas}

Los contextos definidos como fase 10 muestran más cercanía a la tradición Paracas porque incluyen ciertos artefactos y estilos parecidos a los procedentes de algunas tumbas de Paracas Cavernas y Ocucaje fase 10. Se distinguen de los contextos más tardíos por los tipos de artefactos asociados, las formas de prendas y su decorado, ciertas prácticas en la preparación del cuerpo del difunto y la creación del fardo a su alrededor ${ }^{1}$.

Los individuos de la fase 10 suelen presentar tatuajes en forma de diseños en color negroazulado en gran escala en las manos, los antebrazos y, en ciertos casos, las piernas, en zonas donde la piel ha sido bien conservada (Tomasto-Cagigao et al. 2013, Maita y Minaya 2014). Estos diseños se han notado también en individuos enterrados en las tumbas del tipo Cavernas en la cima de Cerro Colorado. Se han notado zonas que presentan otros colores que posiblemente representan pintura corporal, pero en estos no ha sido posible definir bien si se trata de diseños formales o marcas producidas por contacto con textiles u otros materiales. Aún en los fardos más grandes de la fase 10, no se emplea un canasto para fortalecer la base. En el caso del fardo transicional WK 157, el individuo presenta pintura corporal y también ha sido colocado posteriormente en un canasto 
funerario, los otros elementos de este gran fardo también combinan características de los contextos de la fase 10, con características de los contextos de la fase 1.

Hay una serie de armas e instrumentos presentes solamente en los contextos de la fase $10 \mathrm{~A}$ en Wari Kayan y recurrente en ellos (Tabla 2). Estos artefactos, como cuchillos de punta de obsidiana, peines, «coladores» e instrumentos de viento construidos de caña o de hueso, también ocurren en las tumbas de Paracas Cavernas. También el tallado fino y complejo en varas pulidas de madera caracteriza ciertos contextos de este grupo y no se encuentra entre los contextos con estilos relacionados con Nasca. Los instrumentos musicales, armas y varas talladas se encuentran solamente en contextos masculinos, mientras que los coladores y peines se encuentran con los hombres y las mujeres.

Los adornos de metal suelen ser grandes y complejos en hombres y mujeres de las fases $10 \mathrm{~A} \mathrm{y}$ 10B y también en los contextos transicionales WK 94 y WK 157 (Tabla 3). Los detalles repujados, el recorte del adorno en contornos complejos y las figuras humanas y felinas muestran el dominio de las técnicas y la importancia del trabajo de metal en estos contextos, una característica compartida con varios contextos mortuorios de Ocucaje fase 10. También en ciertos contextos tempranos -Cateo 99 tumba 2, WK 199, WK 157 y WK 16 de la fase 1A - se ha observado una pinza de metal y dos discos repujados unidos por una banda delgada y doblada. El color de los artefactos varía entre el oro amarillento y un color cobrizo que marca una mayor presencia de otros metales (ver Velarde y Castro, en este volumen).

Entre los objetos plumarios de este grupo, predominan las plumas de papagayo (Ara ararauna) amarillas y a veces azules (Tabla 4). La forma Abanico 1 (Yacovleff 1933: 151, fig. 6) aparece con plumas amarillas en la fase 10 y en ciertos fardos masculinos posteriores. Un penacho triangular de plumas amarradas a una varita de madera (Yacovleff 1933: 149) es recurrente en los fardos masculinos WK 114, 147 y 157, mientras que un tipo de borla construida con un anillo y pendientes de caña con plumas amarillas y negras, se encuentra en los fardos WK 199 y WK 352, lo que sugiere la posibilidad de que los mismos artesanos hayan adornado ciertos fardos.

Los contextos femeninos de la fase 10 suelen estar adornados con pendientes triangulares de piel, cubiertos por plumas amarillas adheridas (Peters 2011: 240, fig. 5) ${ }^{2}$, generalmente dos pares cosidos a las telas de la capa externa de exposición, aunque el fardo WK 93 lleva siete pares. Una mujer de la fase 1, WK 326, también lleva dos pares de estos adornos de piel plumada. Dos pares de estos adornos fueron recuperados entre prendas fragmentarias en WK 352, un individuo de posible sexo masculino cuya indumentaria no incluye las prendas típicamente masculinas. También cuatro adornos de este tipo acompańaban un tocado plumado que imita la forma de una cabeza y patas de zorro, encima de Arena Blanca 157 (Cateo III-A tumba 35), un fardo parecido a los de Wari Kayan de la fase 1B. Estos dos fardos masculinos (WK 352 y AB 157) incluyen otros elementos más típicos de Ocucaje, lo que abre la posibilidad de que el adorno plumario asociado al género femenino en Wari Kayan sea una seńa de grupo social.

Ciertos tipos de prendas y técnicas decorativas caracterizan la fase 10A. Predomina la tela llana de algodón. En los fardos masculinos aparecen túnicas cerradas (cosidas debajo de la abertura de los brazos) y faldas de algodón natural con flecaduras de algodón retorcido, cuyas formas corresponden a las túnicas 1 y 3 a y a las faldas 1 a y 1 b (Tablas 5 y 6 , Figuras $2 \mathrm{a}, 2$ c y $4 \mathrm{a}-4 \mathrm{c}$ ). La forma de túnica más común en los fardos de la fase 10A se compone de una tela llana con franjas tejidas, creadas como bandas independientes y cosidas, superpuestas a los márgenes del cuello y los márgenes laterales. La costura de las dos bandas que crean las franjas del ruedo siempre deja dos aberturas entre una franja lateral y la franja inferior, un antecedente de esta abertura en las túnicas bordadas. Una guardilla interior bordada repite las figuras representadas en las franjas tejidas y una larga y abundante flecadura de hilos policromos retorcidos marca los hombros. Los ejemplos mejor conservados de la túnica 2 son de lados abiertos y tienen una flecadura de largas y angostas bandas tejidas en su margen inferior. 
Tabla 2. Distribución de instrumentos y armas entre los contextos estudiados y la muestra comparativa

\begin{tabular}{|c|c|c|c|c|c|c|c|c|}
\hline Elemento & Características & $10 \mathrm{~A}(\mathrm{M})$ & $10(\mathrm{~F})$ & $10 \mathrm{~B}(\mathrm{M})$ & $1 \mathrm{~A}(\mathrm{M})$ & $1(\mathrm{~F})$ & $1 \mathrm{~B}(\mathrm{M})$ & $2(\mathrm{M})$ \\
\hline Cuchillo & $\begin{array}{l}\text { Punta triangular de obsidiana; } \\
\text { mango de madera }\end{array}$ & $\begin{array}{l}\text { Cat99t2, } \\
\text { WK 34, } \\
\text { WK } 110\end{array}$ & & & & & & \\
\hline Quena & $\begin{array}{l}\text { Tubo de caña, hueso de ave } \\
\text { o hueso de mamífero con } \\
\text { agujeros perforados y ranura } \\
\text { en la embocadura }\end{array}$ & $\begin{array}{l}\text { WK 34, } \\
\text { WK 39, } \\
\text { WK } 199\end{array}$ & & & & & & \\
\hline Antara & $\begin{array}{l}2 \text { tubos de cańa o hueso de } \\
\text { ave amarrados }\end{array}$ & $\begin{array}{l}\text { Cat99t2, } \\
\text { WK } 35\end{array}$ & & & & & & \\
\hline Colador & $\begin{array}{l}\text { Varita de cańa amarrada a un } \\
\text { anillo de cańa con una malla } \\
\text { de junco anudado }\end{array}$ & $\begin{array}{l}\text { WK } 114, \\
\text { WK } 199 \text {, } \\
\text { WK } 210\end{array}$ & $\begin{array}{l}\text { WK } 70, \\
\text { WK } 81\end{array}$ & & & & & \\
\hline Peine & $\begin{array}{l}\text { Cańa partida y amarrada } \\
\text { con junco, dientes de caña o } \\
\text { madera en } 2 \text { lados }\end{array}$ & $\begin{array}{l}\text { WK } 114, \\
\text { WK } 199\end{array}$ & $\begin{array}{l}\text { WK } 70, \\
\text { WK } 87, \\
\text { WK } 93\end{array}$ & & & & & \\
\hline Vara 1 & $\begin{array}{l}\text { Vara delgada, pulida con } \\
\text { un extremo tallado a una } \\
\text { punta (lanza), (*tallado como } \\
\text { harpón) }\end{array}$ & $\begin{array}{l}\text { WK } 110 \text {, } \\
\text { WK } 136, \\
\text { WK } 147, \\
\text { WK } 199^{*}\end{array}$ & & $\begin{array}{l}\text { WK } 49 \text {, } \\
\text { WK } 157\end{array}$ & $\begin{array}{l}\text { WK } 16 \text {, } \\
\text { WK } 94, \\
\text { WK } 292 \\
(190), \text { WK } \\
420\end{array}$ & & $\begin{array}{l}\text { WK 4, WK } \\
12(382), \\
\text { WK 38, } \\
\text { WK 190 } \\
(290), \text { WK } \\
310, \text { WK } \\
378, \text { WK } \\
451\end{array}$ & $\begin{array}{l}\text { WK } 253 \text {, } \\
\text { WK } 319\end{array}$ \\
\hline $\begin{array}{l}\text { Varita } \\
\text { tallada }\end{array}$ & $\begin{array}{l}\text { Vara fina de madera de forma } \\
\text { compleja, tallada y pulida }\end{array}$ & $\begin{array}{l}\text { WK } 199, \\
\text { WK } 210\end{array}$ & & & & & & \\
\hline Estólica & $\begin{array}{l}\text { Vara pulida con un soporte } \\
\text { de mano tallado de hueso y } \\
\text { una piedra o diente pulida } \\
\text { alargada, amarrado a un } \\
\text { angulo en la punta }\end{array}$ & & & & & & & \\
\hline $\begin{array}{l}\text { Flecha } \\
\text { grabada }\end{array}$ & Caña o madera pirograbada & $\begin{array}{l}\text { WK } 136 \text {, } \\
\text { WK } 349\end{array}$ & & & & & & \\
\hline Bastón 1 & $\begin{array}{l}\text { Bastón de madera de } \\
\text { superficie natural, con pares } \\
\text { de nudos, con un amarre de } \\
\text { tendones entre ellos }\end{array}$ & & & & & & WK 27 & WK 253 \\
\hline Bastón 2 & $\begin{array}{l}\text { Bastón anillado grueso, aprox. } \\
1 \text { m de largo; los anillos han } \\
\text { cubierto gran parte de la } \\
\text { superficie (*con anillos de } \\
\text { cabello y plumas) }\end{array}$ & WK 210 & & WK 438 & & & $\begin{array}{l}\text { AB 157, } \\
\text { WK } 190 \\
(290)^{*}, W K \\
262, \text { WK } \\
310, \text { WK } \\
451\end{array}$ & $\begin{array}{l}\text { WK 253, } \\
\text { WK 319* }\end{array}$ \\
\hline Bastón 3 & $\begin{array}{l}\text { Bastón anillado grueso y } \\
\text { corto, aprox. } 40 \mathrm{~cm} \text { de largo; } \\
\text { en ciertos casos ha servido de } \\
\text { mango de porra. }\end{array}$ & $\begin{array}{l}\text { WK } 114, \\
\text { WK } 147\end{array}$ & & WK 35 & $\begin{array}{l}\text { WK } 16, \\
\text { WK } 91, \\
\text { WK } 243 \text {, } \\
\text { WK } 292 \\
(190)\end{array}$ & & $\begin{array}{l}\text { WK 4, WK } \\
262, \text { WK } \\
378, \text { WK } \\
451\end{array}$ & \\
\hline
\end{tabular}


Tabla 3. Distribución de formas de adornar el cuerpo y la cabeza entre los contextos estudiados y la muestra comparativa

\begin{tabular}{|c|c|c|c|c|c|c|c|c|}
\hline Elemento & Características & $10 \mathrm{~A}(\mathrm{M})$ & $10(\mathrm{~F})$ & $\begin{array}{l}10 \mathrm{~B} \\
(\mathrm{M})\end{array}$ & $1 \mathrm{~A}(\mathrm{M})$ & $1(\mathrm{~F})$ & $1 \mathrm{~B}(\mathrm{M})$ & $2(\mathrm{M})$ \\
\hline $\begin{array}{l}\text { Tatuaje o } \\
\text { pintura } \\
\text { corporal }\end{array}$ & $\begin{array}{l}\text { Diseños en la piel, } \\
\text { mayormente de color } \\
\text { negro-azul, residuos de } \\
\text { otros colores }\end{array}$ & $\begin{array}{l}\text { WK } 110 \text {, } \\
\text { WK } 114, \\
\text { WK } 199\end{array}$ & $\begin{array}{l}\text { WK } 70 \text {, } \\
\text { WK } 81 \text {, } \\
\text { WK } 86 \text {, } \\
\text { WK } 113 \text {, } \\
\text { WK } 437\end{array}$ & $\begin{array}{l}\text { WK } \\
157\end{array}$ & & $\begin{array}{l}\text { WK } \\
28^{*}\end{array}$ & & \\
\hline $\begin{array}{l}\text { Adorno } \\
\text { metálico }\end{array}$ & $\begin{array}{l}\text { Adornos de oro } \\
\text { laminar con contornos } \\
\text { complejos y diseños } \\
\text { repujados: diadema, } \\
\text { nariguera, discos, } \\
\text { penacho colgante, y/o } \\
\text { brazalete (o fragmentos } \\
\text { identificables) }\end{array}$ & $\begin{array}{l}\text { Cat99t2; } \\
\text { WK } 35 \text {, } \\
\text { WK } 43 \text {, } \\
\text { WK } 114 \text {, } \\
\text { WK } 157\end{array}$ & $\begin{array}{l}\text { WK 86, } \\
\text { WK } 149 \\
\text { (WK 81, } \\
\text { WK 93, } \\
\text { WK 113) }\end{array}$ & & & & & \\
\hline $\begin{array}{l}\text { Pinzas } \\
\text { metálicas }\end{array}$ & $\begin{array}{l}\text { Dos discos repujados } \\
\text { de oro-cobre laminar } \\
\text { unidos por una banda } \\
\text { doblada }\end{array}$ & $\begin{array}{l}\text { Cat99t2, } \\
\text { WK } 199\end{array}$ & & $\begin{array}{l}\text { WK } \\
157\end{array}$ & WK 16 & & & \\
\hline $\begin{array}{l}\text { Adorno } \\
\text { metálico }\end{array}$ & $\begin{array}{l}\text { Adornos de oro laminar } \\
\text { de tamaño mediano } \\
\text { y contornos simples: } \\
\text { diadema, nariguera, } \\
\text { discos }\end{array}$ & & & & WK 16 & & $\begin{array}{l}\text { WK } 12 \\
(382), \text { WK } \\
89, \text { WK } \\
190(290) \text {, } \\
\text { WK 310, } \\
\text { WK 378, } \\
\text { WK } 451\end{array}$ & $\begin{array}{l}\text { WK } \\
253, \\
\text { WK } 319\end{array}$ \\
\hline $\begin{array}{l}\text { Adorno de } \\
\text { cabello }\end{array}$ & $\begin{array}{l}\text { Mechas envueltas, } \\
\text { cordones hilados o } \\
\text { trenzados de cabello } \\
\text { humano }\end{array}$ & & & & $\begin{array}{l}\text { WK 26, WK } \\
\text { 91, WK } 217\end{array}$ & & WK 4 & \\
\hline $\begin{array}{l}\text { Franja de } \\
\text { cabello }\end{array}$ & $\begin{array}{l}\text { Mechas de cabello } \\
\text { retorcidas o trenzadas } \\
\text { penden de una cuerda }\end{array}$ & & & & & & WK 4 & $\begin{array}{l}\text { WK } \\
253, \\
\text { WK } \\
318, \\
\text { WK } 319\end{array}$ \\
\hline $\begin{array}{l}\text { Gorro de } \\
\text { pelo }\end{array}$ & $\begin{array}{l}\text { Tocado anillado de } \\
\text { cabello o pelo animal, } \\
\text { con mechas y plumas }\end{array}$ & & & & WK 26 & $\begin{array}{l}\text { WK } \\
226\end{array}$ & $\begin{array}{l}\text { WK } 89 \text {, } \\
\text { WK } 188 \text {, } \\
\text { WK } 190 \\
(290), \text { WK } \\
451\end{array}$ & \\
\hline $\begin{array}{l}\text { Collar de } \\
\text { caracoles }\end{array}$ & $\begin{array}{l}\text { Bandas de totora } \\
\text { entrelazada con } \\
\text { caracoles perforados, } \\
\text { cosidas en forma de un } \\
\text { óvalo con una abertura } \\
\text { superior }\end{array}$ & & & & $\begin{array}{l}\text { WK } 16, \text { WK } \\
421\end{array}$ & & $\begin{array}{l}\text { WK 38, } \\
\text { WK } 190 \\
(290)\end{array}$ & \\
\hline $\begin{array}{l}\text { Tocado } \\
\text { animal }\end{array}$ & $\begin{array}{l}\text { Piel de zorro en la cima } \\
\text { del fardo (* piel plumada } \\
\text { con hocico de zorro) }\end{array}$ & & & $\begin{array}{l}\text { WK } \\
49, \\
\text { WK } \\
157\end{array}$ & $\begin{array}{l}\text { WK 91, WK } \\
94, \text { WK } 217, \\
\text { WK 243, WK } \\
292(190), \\
\text { WK 421, WK } \\
438\end{array}$ & & $\begin{array}{l}\text { AB } 157^{*} \text {, } \\
\text { WK } 190 \\
(290), \text { WK } \\
378\end{array}$ & \\
\hline
\end{tabular}

* Basado en Maita and Minaya 2014 
Tabla 4. Distribución de adornos plumarios entre los contextos estudiados y la muestra comparativa

\begin{tabular}{|c|c|c|c|c|c|c|c|c|}
\hline Elemento & Características & $10 \mathrm{~A}(\mathrm{M})$ & $10(\mathrm{~F})$ & $10 \mathrm{~B}(\mathrm{M})$ & $1 \mathrm{~A}(\mathrm{M})$ & $1(\mathrm{~F})$ & $1 \mathrm{~B}(\mathrm{M})$ & $2(\mathrm{M})$ \\
\hline Penacho 1 & $\begin{array}{l}\text { Triángulo de plumas } \\
\text { amarillas amarradas a } \\
\text { un alfiler de madera }\end{array}$ & $\begin{array}{l}\text { WK } 114, \\
\text { WK } 147 \text {, } \\
\text { WK } 157\end{array}$ & & & & & & \\
\hline Penacho 2 & $\begin{array}{l}\text { Cono de plumas pardo- } \\
\text { grises alrededor de } 1-2 \\
\text { plumas largas }\end{array}$ & & & & $\begin{array}{l}\text { WK 16, } \\
\text { WK 49, } \\
\text { WK 91, } \\
\text { WK 94, } \\
\text { WK } 190 \\
\text { (fardo 290), } \\
\text { WK 217, } \\
\text { WK 243, } \\
\text { WK 292 } \\
\text { (fardo 190), } \\
\text { WK 323, } \\
\text { WK 392, } \\
\text { WK 421, } \\
\text { WK } 438\end{array}$ & & WK 378 & \\
\hline Penacho 3 & $\begin{array}{l}\text { Borla creada a base } \\
\text { de un anillo de caña } \\
\text { con hileras de plumas } \\
\text { amarradas }\end{array}$ & WK 199 & & WK 352 & $\begin{array}{l}\text { WK } 16 \text {, } \\
\text { WK } 49\end{array}$ & & $\begin{array}{l}\text { AB } 157, \\
\text { WK } 310 \text {, } \\
\text { WK } 262\end{array}$ & \\
\hline Pendiente & $\begin{array}{l}\text { Triángulo de capas } \\
\text { de piel cubierto con } \\
\text { plumas de guacamayo } \\
\text { adheridas con resina }\end{array}$ & & $\begin{array}{l}\text { WK 70, } \\
\text { WK } 81 \text {, } \\
\text { WK 93, } \\
\text { WK } 113 \text {, } \\
\text { WK } 149\end{array}$ & WK 352 & AB 157 & $\begin{array}{l}\text { WK } \\
326\end{array}$ & & \\
\hline Abanico 1 & $\begin{array}{l}\text { Plumas unidas con un } \\
\text { arco de torzal de totora, } \\
\text { de donde salen tallos de } \\
\text { totora que se unen en } \\
\text { dos amarres de algodón } \\
\text { para formar un mango }\end{array}$ & $\begin{array}{l}\text { Cat99t2, } \\
\text { WK } 114\end{array}$ & & WK 157 & $\begin{array}{l}\text { WK } 16 \\
\text { (mini), } \\
\text { WK 49, } \\
\text { WK 91, } \\
\text { WK 217, } \\
\text { WK } 421\end{array}$ & & $\begin{array}{l}\text { WK } 12 \\
\text { (fardo } \\
382 \text { ) }\end{array}$ & WK 253 \\
\hline Abanico 2 & $\begin{array}{l}\text { Plumas unidas por un } \\
\text { arco sólido de torzal de } \\
\text { totora, del cual salen } \\
\text { tallos que se entretejen } \\
\text { alrededor de un mango } \\
\text { de cańa }\end{array}$ & & & & & & $\begin{array}{l}\text { WK } 190 \\
\text { (fardo } \\
\text { 290), } \\
\text { WK 351 }\end{array}$ & WK 319 \\
\hline $\begin{array}{l}\text { Arco } \\
\text { plumado }\end{array}$ & $\begin{array}{l}\text { Tocado de palitos en } \\
\text { forma arqueada, con } \\
\text { adornos de plumas }\end{array}$ & & & & & & $\begin{array}{l}\text { WK } 188 \text {, } \\
\text { WK } 378\end{array}$ & \\
\hline
\end{tabular}


Tabla 5. Distribución de formas de túnica entre los contextos estudiados y la muestra comparativa

\begin{tabular}{|c|c|c|c|c|c|c|c|c|}
\hline Formas & Características & $10 \mathrm{~A}(\mathrm{M})$ & $10(\mathrm{~F})$ & $10 \mathrm{~B}(\mathrm{M})$ & $1 \mathrm{~A}(\mathrm{M})$ & $1(\mathrm{~F})$ & $1 \mathrm{~B}(\mathrm{M})$ & $2(\mathrm{M})$ \\
\hline $\begin{array}{l}\text { Túnica 1a } \\
\text { (unku) }\end{array}$ & $\begin{array}{l}\text { Tela de algodón con costura } \\
\text { lateral, flecos retorcidos en los } \\
\text { hombros y el ruedo inferior }\end{array}$ & $\begin{array}{l}\text { WK } 114, \\
\text { WK } 157 \text {, } \\
\text { WK } 199\end{array}$ & & & & & & \\
\hline $\begin{array}{l}\text { Túnica 1b } \\
\text { (unku) }\end{array}$ & $\begin{array}{l}\text { Tela de algodón con flecos } \\
\text { retorcidos en los hombros y } \\
\text { costura lateral y anillado en el } \\
\text { margen del cuello }\end{array}$ & $\begin{array}{l}\text { WK } 114, \\
\text { WK } 199\end{array}$ & & WK 157 & & & & \\
\hline $\begin{array}{l}\text { Túnica 1c } \\
\text { (unku) }\end{array}$ & $\begin{array}{l}\text { Tela de camélido azul con flecos } \\
\text { retorcidos policromos largos en } \\
\text { los hombros y cortos en el ruedo } \\
\text { inferior }\end{array}$ & & & & $\begin{array}{c}\text { WK } 292 \\
190)\end{array}$ & & & \\
\hline $\begin{array}{l}\text { Túnica } 2 \\
\text { (unku) }\end{array}$ & $\begin{array}{l}\text { Tela llana, franjas de tela llana } \\
\text { con sustitución de urdimbres } \\
\text { suplementarias, cosidos } \\
\text { superpuestos, guardilla interior } \\
\text { bordada, flecadura retorcida } \\
\text { policroma en los hombros y flecos } \\
\text { largos tejidos en el ruedo inferior }\end{array}$ & $\begin{array}{l}\text { Cat99t2, } \\
\text { WK } 114, \\
\text { WK } 136, \\
\text { WK } 147, \\
\text { WK } 210 \text {, } \\
\text { WK } 355 \text {, } \\
\text { WK } 381\end{array}$ & & WK 157 & $\begin{array}{l}\text { WK } 49 \text {, } \\
\text { WK } 94\end{array}$ & & & \\
\hline $\begin{array}{l}\text { Túnica } 3 \\
\text { (unku) }\end{array}$ & $\begin{array}{l}\text { Tela llana de algodón, franjas } \\
\text { anchas bordadas en el abertura de } \\
\text { cuello, flecos largos retorcidos de } \\
\text { algodón en los hombros }\end{array}$ & & & WK 157 & WK 49 & & & \\
\hline $\begin{array}{l}\text { Túnica } 4 \\
\text { (unku) }\end{array}$ & $\begin{array}{l}\text { Tela llana con franjas bordadas en } \\
\text { el cuello, flecos largos retorcidos } \\
\text { en los hombros, flecos retorcidos } \\
\text { en el ruedo inferior }\end{array}$ & WK 114 & & $\begin{array}{l}\text { WK } 157 \text {, } \\
\text { WK } 438\end{array}$ & $\begin{array}{l}\text { WK } 49 \text {, } \\
\text { WK } 94, \\
\text { WK } 292 \\
(190) \text {, } \\
\text { WK } 421\end{array}$ & & & \\
\hline $\begin{array}{l}\text { Túnica 5a } \\
\text { (unkuña) }\end{array}$ & $\begin{array}{l}\text { Tela llana con franjas en el cuello } \\
\text { y franjas en el ruedo, con dos } \\
\text { aberturas donde la franja lateral } \\
\text { llega a la franja del extremo, sin } \\
\text { flecos }\end{array}$ & & & & $\begin{array}{l}\text { WK 16, } \\
\text { WK 24, } \\
\text { WK 26, } \\
\text { WK 49, } \\
\text { WK 91, } \\
\text { WK 94, } \\
\text { WK 217, } \\
\text { WK 243, } \\
\text { WK } 292(190) \text {, } \\
\text { WK } 421, \\
\text { WK } 438\end{array}$ & & & WK 319 \\
\hline $\begin{array}{l}\text { Túnica 5b } \\
\text { (unkuña) }\end{array}$ & $\begin{array}{l}\text { Tela llana con franjas en el } \\
\text { abertura del cuello y franjas en el } \\
\text { ruedo, con dos aberturas donde } \\
\text { la franja lateral llega a la franja del } \\
\text { extremo, con flecos retorcidos o } \\
\text { anillados adyacentes }\end{array}$ & & & & $\begin{array}{l}\text { WK } 243 \text {, } \\
\text { WK } 421\end{array}$ & & $\begin{array}{l}\text { WK 262, } \\
\text { WK } 310 \text {, } \\
\text { WK } 378\end{array}$ & WK 318 \\
\hline $\begin{array}{l}\text { Túnica } 6 \\
\text { (unkuña) }\end{array}$ & $\begin{array}{l}\text { Tela llana con abertura horizontal, } \\
\text { flecos retorcidos en los hombros } \\
\text { [forma casulla] }\end{array}$ & & & & & & & $\begin{array}{l}\text { WK } 253 \text {, } \\
\text { WK } 319\end{array}$ \\
\hline $\begin{array}{l}\text { Túnica } 7 \\
\text { (unkuña) }\end{array}$ & $\begin{array}{l}\text { Tela llana con franjas angostas } \\
\text { continuas en los cuatro márgenes, } \\
\text { con flecos retorcidos adyacentes } \\
\text { [grupo anako] }\end{array}$ & & & & & & & WK 319 \\
\hline
\end{tabular}


Tabla 6. Distribución de formas de falda y wara entre los contextos estudiados y la muestra comparativa

\begin{tabular}{|c|c|c|c|c|c|c|c|c|}
\hline Formas & Características & $10 \mathrm{~A}(\mathrm{M})$ & $10(\mathrm{~F})$ & $10 \mathrm{~B}(\mathrm{M})$ & $1 \mathrm{~A}(\mathrm{M})$ & $1(\mathrm{~F})$ & $1 \mathrm{~B}(\mathrm{M})$ & $2(\mathrm{M})$ \\
\hline Falda 1a & $\begin{array}{l}\text { Tela de algodón con tiras en } \\
\text { entrelazado diagonal, flecadura } \\
\text { retorcida creada aparte y cosida } \\
\text { al margen }\end{array}$ & WK 136 & & WK 157 & & & & \\
\hline Falda $1 \mathrm{~b}$ & $\begin{array}{l}\text { Tela de algodón con tiras en } \\
\text { entrelazado diagonal, flecos } \\
\text { retorcidos creados en la orilla }\end{array}$ & WK 136 & & WK 157 & & & & \\
\hline Falda 2a & $\begin{array}{l}\text { Tela llana variable, } 2 \text { tiras en } \\
\text { entrelazado diagonal con tapas } \\
\text { anilladas, franjas bordadas } \\
\text { directamente [sin flecos] }\end{array}$ & WK 114 & & WK 157 & $\begin{array}{l}\text { WK 16, } \\
\text { WK } 49\end{array}$ & & & \\
\hline Falda $2 b$ & $\begin{array}{l}\text { Tela llana variable, } 2 \text { tiras en } \\
\text { entrelazado diagonal con tapas } \\
\text { anilladas y flecadura, franjas } \\
\text { bordadas directamente, flecos } \\
\text { retorcidos }\end{array}$ & & & WK 157 & $\begin{array}{l}\text { WK } 49 \text {, } \\
\text { WK } 94, \\
\text { WK } 243 \text {, } \\
\text { WK } 421\end{array}$ & & $\begin{array}{l}\text { WK } 12 \\
(382), \\
\text { WK } 378\end{array}$ & WK 318 \\
\hline Falda 3 & $\begin{array}{l}\text { Tela llana variable, franjas } \\
\text { bordadas, flecos tejidos }\end{array}$ & & & & WK 217 & & $\begin{array}{l}\text { WK } 12 \\
(382), \\
\text { WK } 378\end{array}$ & \\
\hline Wara 1a & $\begin{array}{l}\text { Tela de algodón, tiras en } \\
\text { entrelazado diagonal en las } \\
\text { esquinas de un extremo, flecos } \\
\text { cortos }\end{array}$ & & & & WK 91 & & & \\
\hline Wara 1b & $\begin{array}{l}\text { Tela de algodón, tiras en } \\
\text { entrelazado diagonal en } \\
\text { esquinas de un extremo } \\
\text { con tapas anilladas, franjas } \\
\text { bordadas, flecos cortos }\end{array}$ & & & WK 35 & $\begin{array}{l}\text { WK 91, } \\
\text { WK } 421\end{array}$ & & $\begin{array}{l}\text { WK } 89, \\
\text { WK 262, } \\
\text { WK } 310\end{array}$ & \\
\hline Wara 2 & $\begin{array}{l}\text { Tela de camélido, franjas } \\
\text { bordadas, tiras en entrelazado } \\
\text { diagonal con tapas anilladas y } \\
\text { grandes borlas policromas }\end{array}$ & & & & $\begin{array}{l}\text { WK 91, } \\
\text { WK } 364 \\
(23)\end{array}$ & & & \\
\hline Wara 3 & $\begin{array}{l}\text { Tela de algodón o camélido, } \\
\text { con franjas bordadas diferentes } \\
\text { en cada extremo; tiras en } \\
\text { entrelazado diagonal en el } \\
\text { margen lateral cerca de un } \\
\text { extremo, con tapas anilladas }\end{array}$ & & & & & & $\begin{array}{l}\text { WK } 89, \\
\text { WK } 310 \text {, } \\
\text { WK } 378\end{array}$ & \\
\hline $\begin{array}{l}\text { Wara } 7 \\
\text { (grupo } \\
\text { anako) }\end{array}$ & $\begin{array}{l}\text { Tela llana con franjas bordadas } \\
\text { en los cuatro márgenes, tiras } \\
\text { en entrelazado diagonal por } \\
\text { las cuatro esquinas, con tapas } \\
\text { anilladas. }\end{array}$ & & & & & & $\begin{array}{l}\text { WK 38, } \\
\text { WK } 89, \\
\text { WK } 190 \\
(290)\end{array}$ & WK 318 \\
\hline
\end{tabular}


La forma de manto típica de Paracas Necrópolis aparece bien establecida en la fase 10A: el Manto 1, construido con dos paños de tela llana formando el campo central y dos bandas de tela llana cosidas a los márgenes laterales (Tabla 7, Figura 6a y 6b). El bordado de las franjas cubre totalmente estas bandas laterales y se extiende en los cabos de urdimbre creando la forma de "corchetes» ([ ]). En un manto terminado siempre aparece una guardilla interior de figuritas orientadas con la cabeza hacia la franja, versiones del mismo ícono representado en ella. Una flecadura de hilos retorcidos está cosida al margen de la franja y un festón anillado complejo (Hoces de la Guardia y Brugnoli 2006) cubre esta unión, realizado en color rojo predominante. Este tipo de manto predominantemente se asocia a los fardos masculinos.

Las telas de tocado, denominadas «ñañaka» por Tello y sus colegas (Tabla 8), se caracterizan por hilados muy finos y de torsión fuerte (crepe) y una tela flexible de baja densidad. El Turbante 1 se compone de dos pańos largos y angostos, con franjas angostas en un estilo Lineal 2, un festón anillado entretejido y zonas de costura monocroma con cambio del sentido de las puntadas en diagonal en las esquinas (Peters 2017a). Suelen encontrarse en la cabeza del individuo o la cima de un fardo, asociado a las fases 10A, 10B y 1A, enrollado y torcido en forma de turbante. Los hombres también aparecen con una gran variedad de elementos de tocado, los que incluyen cuerdas, hondas y bandas de diversas técnicas (Tabla 9). Las formas más típicas son la banda tubular de técnica de anillado (banda 3a), terminando en dos o tres «dedos» tubulares y el tocado de panel anudado (banda $2 \mathrm{~b}$ ) con secciones en entrelazado diagonal complejo y tapiz modificado, terminando en una larga flecadura de hilos policromos. La forma de este tocado anudado, recurrente en Paracas Necrópolis, es una versión más ancha de la banda 2a, de amplia distribución en contextos de la tradición Paracas, asociada a las tumbas de Ocucaje y de Paracas Cavernas (Medina 2009).

En los estilos figurativos predomina el estilo Lineal 1 (Peters 2014), tanto en las franjas bordadas como en las bandas tejidas que se utilizan como franja del cuello y del margen de la Túnica 2 (Figura $2 \mathrm{~b}$ ). La creación de figuras por sustitución de urdimbres suplementarias en tres o cuatro colores en una tela llana de color rojo, lleva a diseños lineales con ciertas características,

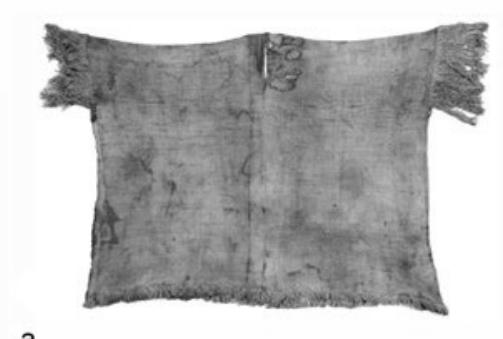

a

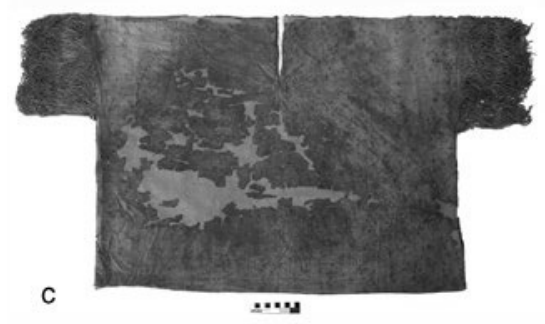

b
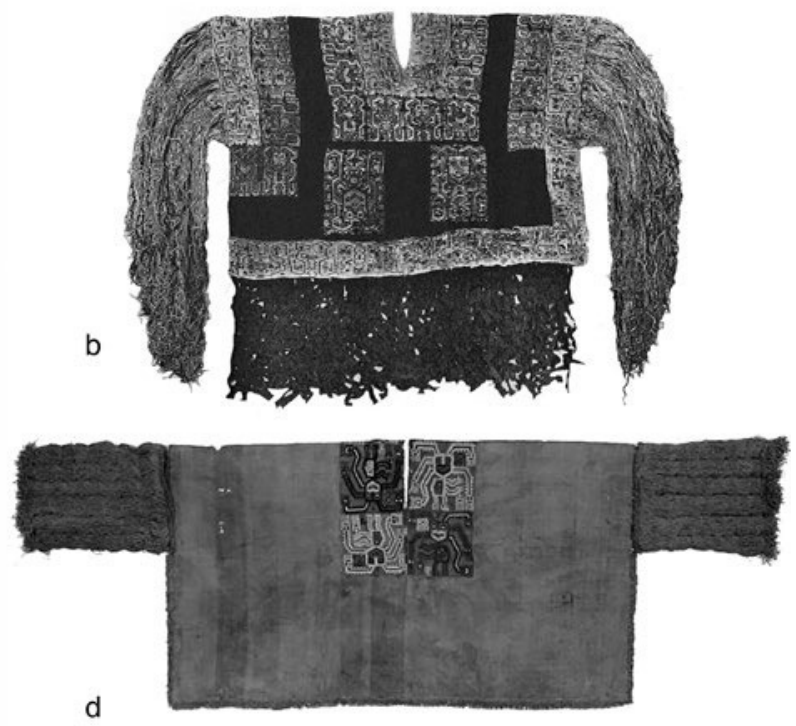

Figura 2. Formas de túnica predominantes en contextos masculinos de la fase 10 y transicionales (A. H. Peters): a. Túnica 1 , WK 157 espécimen 31 (basado en foto del proyecto Telefónica, MNAAHP). b. Túnica 2, WK 114 espécimen 27 (basado en foto de Coles, AMNH 1938). c. Túnica 3a, WK 199 espécimen 22 (basado en foto de Peters, MNAAHP 2012). d. Túnica 3b, WK 157 espécimen 57 (basado en foto del proyecto Telefónica, MNAAHP). 

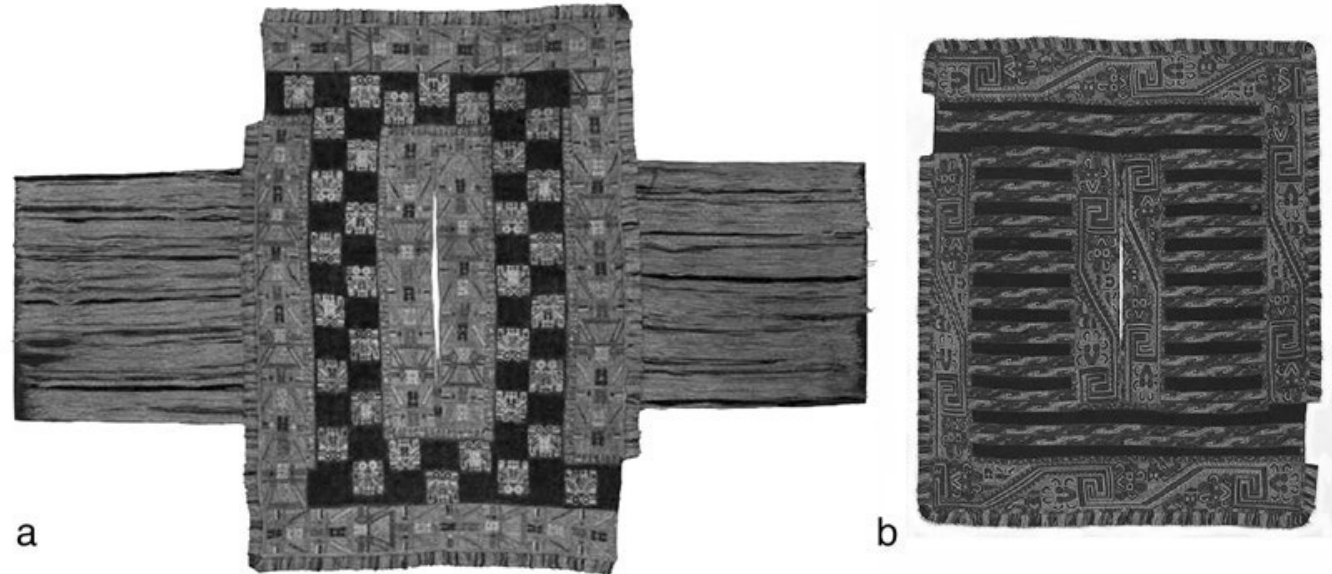

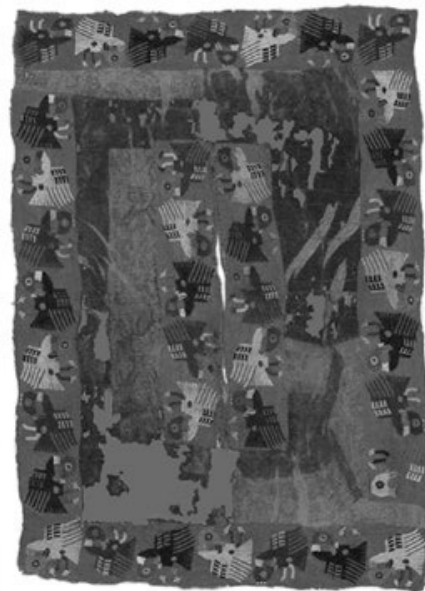

C

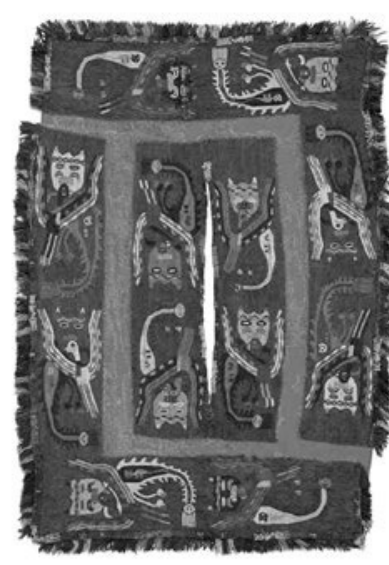

d

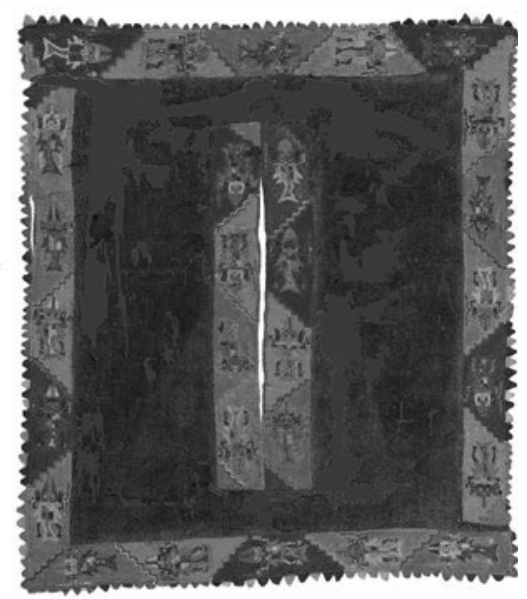

e

Figura 3. Formas de túnica predominantes en contextos masculinos transicionales y de la fase 1 (A. H. Peters): a. Túnica 4, WK 94 espécimen 50 (basado en foto del proyecto Telefónica, MNAAHP). b. Túnica 5, WK 421 espécimen 44 (basado en foto del proyecto Telefónica, MNAAHP). c. Túnica 5, WK 421 espécimen 102 (basado en foto del proyecto Telefónica, MNAAHP). d. Túnica 5, WK 310 espécimen 38 (basado en foto del proyecto Telefónica, MNAAHP). e. Túnica 5, WK 12 (fardo 382) espécimen 46 (basado en foto del proyecto Telefónica, MNAAHP).

reproducidas también en las versiones bordadas (Desrosiers 2008) ${ }^{3}$. El juego de indumentaria típico de los fardos masculinos está constituido por una Túnica 2 y un Manto 1 que representan el mismo ícono. Las telas de tocado llevan otro estilo de bordar, variantes del estilo Lineal 2, también de un fondo rojo. Las bandas del tocado de los individuos y fardos masculinos también llevan figuras lineales simples, desarrolladas en el anudado, el tapiz modificado, el anillado o las urdimbres suplementarias. Los elementos del tocado no forman un juego con las otras prendas en los estilos que caracterizan la fase $10 \mathrm{~A}$.

El traje femenino de la fase 10 todavía requiere de mayor definición por haberse encontrado en estado fragmentario en los casos analizados. Las prendas definidas corresponden a un manto femenino de tela roja con una franja y guardilla interior bordadas en estilo Lineal 1. Las telas de tocado femeninos se componen de dos paños más anchos que los paños del tocado masculino, con franjas bordadas de diseño variado (v.g. Peters 2011, 238, fig. 3). Otras telas con franjas bordadas, 
de proporciones parecidas al manto 2, suelen corresponder al manto, al tocado o a un vestido. Uno o dos cordones gruesos compuestos de hilos policromos de algodón aparecen casi siempre y únicamente en los fardos femeninos (Figura 8a). Posiblemente hayan atado el tocado o el vestido.

En la capa de exposición exterior, el fardo femenino WK 113 llevaba una banda ancha de tela llana con sustitución de urdimbres suplementarias, creando figuras de cuerpo torcido y cabello largo, interpretadas como chamánico por Paul y Turpin (1986) y como sacrificado por Frame (2001), en un estilo lineal (Peters 2011: 239, fig. 4). Este ícono está presente en todos los fardos complejos de Paracas Necrópolis, en todos los estilos representativos y su incidencia en la costa sur corresponde temporalmente al culto mortuorio ligado a este cementerio. La banda terminaba en una gruesa y larga flecadura de hilos retorcidos, con la unión tapada por un tubo anillado. Los cuatro pendientes triangulares de piel plumada han estado cosidos a esta banda.

La fase $10 \mathrm{~B}$ en los fardos masculinos se distingue por la presencia de las Túnicas 3 y 4 con franjas bordadas (Tabla 5; Figuras $2 \mathrm{~d}$ y $3 \mathrm{a}$ ), formas denominadas unku por Tello y sus colegas. La Tunica $3 \mathrm{~b}$ lleva una franja ancha bordada en el cuello y una gruesa flecadura de hilos retorcidos de algodón en los hombros. Posiblemente hay también flecos cortos en la costura lateral, pero la mayoría de estas prendas han sido recuperadas en un estado fragmentario, conservando casi siempre la franja del cuello. Las franjas suelen llevar figuras en un estilo Línea Ancha, aunque existe un ejemplo con un diseńo geométrico Bloc-Color. La túnica 4 lleva una flecadura de hilos retorcidos de fibra de camélido policroma en los hombros, parecida a la túnica 2, pero la flecadura del ruedo inferior es también de hilos retorcidos y las franjas son bordadas, usualmente con una guardilla interior. Los estilos de bordado son diversos: lineal, línea ancha o bloc-color. Estas túnicas aparecen en la mayoría de los fardos transicionales y algunos llevan estilos de bordado que caracterizan la fase 1A. Pueden formar parte de un juego de indumentaria con un manto y una falda.

El manto 2 se caracteriza por franjas relativamente angostas bordadas directamente en los márgenes laterales de los dos paños de la tela base. Aparece en fardos 10B y transicionales (Tabla 7 , Figura 6c). Los estilos de bordado son diversos; incluyen estilos Línea Ancha y un estilo lineal «acordonado» con un color de fondo que se encuentra casi siempre carbonizado —rasgos típicos también de contextos contemporáneos procedentes de la cuenca de Ocucaje. Cuando lleva una guardilla interior, suele ser del estilo «mosaico», con cuadritos de una figura bordada en un solo color. No lleva flecos, pero en algunos casos lleva un festón anillado complejo en segmentos de diferentes colores. A veces forma un juego de indumentaria con una tela de tocado.

Al trazar la inclusión de cada tipo de indumentaria y de otros artefactos en los fardos mortuorios, se hace evidente que los contextos definidos como fase 10 se asocian con una serie de prácticas y estilos compartidos con contextos tardíos de la tradición Paracas. La indumentaria frecuente —el manto 1, los mantos femeninos del estilo Lineal 1 y las túnicas 2 y 4 - es diagnostica de Paracas Necrópolis y atípica en los contextos contemporáneos a Cavernas y Ocucaje y, por ende, ligada específicamente a la tradición Topará. En cambio, la túnica 3 y el manto 2, con los estilos de bordado predominantes en ellos, reflejan las influencias mutuas entre las tradiciones Paracas y Topará que caracterizan el valle de Ica. Es decir, que las características que definen la fase 10 son de diverso carácter cultural e indican la interacción entre grupos sociales contemporáneos.

La evidencia de secuencia cronológica se basa en la distribución de las características y se nota la ausencia de las prácticas, los artefactos y los estilos típicos de fardos de las fases 1 y 2, cuyos estilos se relacionan con el desarrollo de Nasca temprano. Ciertos objetos de técnicas y estilo atípico (Peters 2011: 245, fig. 7), muestran una relación más fuerte con productores de la tradición Paracas. Por ejemplo, en una tumba adyacente al extremo este de Wari Kayan (Cateo 99 tumba 2), la presencia de prendas en tela doble con franjas tejidas y sustitución de urdimbres suplementarias (Paul 1990, lámina 4), demuestran procesos productivos y elementos de diseño que indican la interacción entre productores ligados a diferentes tradiciones textiles. Los estilos "proto-Nasca» de un juego de manto 2 y tela de tocado en el fardo WK 114 (Peters 2011: 244, fig. 9) y un juego de túnica 3 b y falda en 
WK 157, son distintos al Nasca 1 de los fardos posteriores, y más bien análogos a ciertas innovaciones contemporáneas en la cerámica en Paracas Cavernas y en Ocucaje 10B (Menzel et al. 1964).

La secuencia cronológica, sin embargo, no está indicada ni por la secuencia de textiles en las capas de cada fardo complejo, ni por la superposición de los fardos en el cementerio. La ubicación relativa no parece ser producto de procesos de deposición sucesiva como la secuencia de un basural, sino producto de manipulación intencional y ritual. Los fardos complejos fueron construidos en varias ocasiones y es difícil precisar la temporalidad de estos eventos. Las ofrendas accesibles pueden haber sido manipuladas en cada refacción del fardo: entonces, la secuencia observada es producto del orden final creado en cada capa, antes de sellarla con envolturas. Prendas de un estilo novedoso o excepcional suelen hallarse tapadas por otras prendas de un estilo más típico o tradicional (Peters 2017b). Ciertas envolturas muestran evidencia de haber estado expuestas y reutilizadas y ciertos mantos han sido reubicados en la capa exterior. Los fardos complejos y sus ofrendas exteriores han sido colocados en la posición de su excavación arqueológica al final de su historia como objeto de culto ancestral y ciertos fardos más simples también han sido exhumados y recolocados en varias ocasiones. Por lo mismo, el orden de deposición final no corresponde necesariamente a la secuencia de producción de los artefactos o creación de los fardos.

\section{Contextos asociados a una interacción con la tradición Nasca}

Algunos fardos complejos conservan prácticas y artefactos típicos de la fase 10 y además ciertos artefactos e indumentaria típicos de la fase 1. Este grupo de fardos masculinos «transicionales» incluye los fardos más grandes y con mayor número de ofrendas, WK 157 y WK 421, y otros fardos complejos como WK 49 y WK 94. Se propone que estos individuos, líderes sociales en vida, deben haber contribuido a la interacción entre grupos ligados a las tradiciones Paracas tardío, Topará y Nasca inicial y las transformaciones políticas y culturales resultantes. Como ser ancestral, han recibido ofrendas cuyos estilos indican la diversidad de sus orígenes socioculturales y además ofrendas producidas en diferentes momentos históricos. Pueden representar dos generaciones de liderazgo: WK 157 y WK 49 centrados en la fase 10B con ciertos objetos patrimoniales de la fase 10A y ofrendas novedosas de la fase 1 y WK 421 y WK 94 más bien centrados en la fase $1 \mathrm{~A}$ con ciertos objetos patrimoniales de la fase 10 y algunas ofrendas novedosas con rasgos más característicos de la fase $1 \mathrm{~B}$.

El fardo WK 157 lleva dos pieles de zorro, una en la cima de la última capa de exposición y la otra en la penúltima capa. El fardo 49 también llevaba una piel de zorro en la cumbre, inmediatamente debajo de la envoltura externa. Estas pieles marcan el rol activo de estos fardos ancestrales en la fase $1 \mathrm{~A}$. Ausente en fardos de la fase 10, el zorro es un elemento asociado a la mayoría de los fardos masculinos de la fase 1A (Tabla 3) y más escaso en los asignados a las fases $1 \mathrm{~B}$ y 2 . Entre los penachos asociados a los fardos masculinos de la fase 1A, la mayoría tiene una estructura y composición particulares: un alfiler de cańa o hueso con un anillo cónico de plumas pardas alrededor de unas plumas largas amarillas de oropéndola (Psarocolius sp.), otra especie de ave sociable de la ceja de selva. No aparecen instrumentos musicales. Las armas asociadas tienen formas recurrentes: porras, estólicas, manojos de cańas identificadas como partes de flechas, varas pulidas con un extremo puntiagudo y bastones con anillos de tendones.

En los fardos transicionales aparecen versiones de la túnica 4 con bordados en estilos característicos de la fase 1A (Tabla 5). Pero la túnica de lados abiertos típica de este grupo de fardos masculinos no lleva una guardilla interior o flecos en los hombros. Esta túnica 5 (Figura $3 \mathrm{~b}$ y $3 \mathrm{c}$ ) ha sido denominada «unkuña» o «esclavina» por Tello y sus colegas y "ponchito» por Paul. Está constituida por un solo paño tejido con la abertura del cuello creada con tramas discontinuas, con franjas bordadas en el margen del cuello y en el ruedo, dejando las aberturas características. Más pequeñas que los unkus, estas túnicas forman parte de un sistema de vestimenta masculina distinto al de 
la fase 10. Siguen presentes las faldas, pero aparecen también en estos fardos la wara o taparrabo (Tabla 6, Figura 6a-6c). La wara la es una tela larga de algodón con tiras en entrelazado diagonal cosidas a las esquinas de un extremo y flecos retorcidos en este extremo y en $80 \%$ de los márgenes laterales. La wara 1b lleva franjas bordadas angostas en el extremo y parte de los márgenes laterales y las tiras terminan en una tapa de anillado tubular y flecos. La wara 2 suele ser una tela llana de camélido de forma más angosta y sus tiras terminan en grandes borlas policromas.

Las telas de tocado masculinas aparecen con proporciones parecidas a las ñañakas anteriores (Tabla 8), pero con otros estilos del bordado, a veces formando un juego con otras prendas (Peters 2017a). Las bandas típicas del tocado masculino (llautus) se crean por entrelazado diagonal (trenzados complejos) de pares de hilos (Tabla 9). La técnica más simple crea cintas monocromas (banda 4a), aunque son más numerosos los llautus más anchos con un diseño que representa una trenza de tres o cuatro elementos (4b), realizada con grupos de hilos en colores contrastantes (Frame 1991). Algunos ejemplares conservan sus cabos cubiertos con un tubo anillado que termina en cuatro o cinco «dedos» tubulares. Ciertos fardos complejos incluyen también bandas en anillado tubular en un estilo distinto de la banda 3a de la fase 10: la banda 3b se construye con hilos más finos en un anillado más compacto, produciendo un llautu plano con figuras más complejas que termina en cinco o seis «dedos» tubulares. Este tipo de llautu suele corresponder en su ícono y su color a un juego de vestimenta bordada presente en el fardo.

El manto 1 sigue presente (Tabla 7), con cambios en los estilos de bordado de las franjas y de la guardilla interior. También hay ejemplos del manto 2 en los fardos transicionales. Los mantos con franjas bordadas en estilo bloc-color con frecuencia no incluyen una guardilla interior. Aparece el manto 3a (Figura 7), con la costura entre los dos pańos centrales tapada por una banda angosta anillada con figuritas policromas. Los bordados de la fase 1A se caracterizan por una gama de estilos bloc-color con figuras relativamente simples realizadas en dos o tres colores, unos ejemplares ligados el estilo línea-ancha y otros con pautas del modo bloc-color bordado o pintado. En las mismas capas de ofrendas aparecen bordados en un estilo bloc-color polícromo, lo que sugiere que se trata de diferentes productores, maestros de este estilo o en el proceso de adoptarlo, más que textiles producidos en épocas diferentes. En todos los estilos de bordado aparecen formas de festón anillado más finas que incorporan figuritas policromas, tapando la unión a una flecadura policroma de hilos retorcidos de camélido.

Paralelamente aparecen diferencias en los estilos Lineales y en su uso en las prendas. El estilo lineal 1 aparece en variantes que incorporan zonas de bordado plano en el color de fondo (Rowe 2015) y con otros colores de fondo como el verde o un azul-púrpura. Se utiliza también para íconos nuevos con antecedentes en las telas dobles de Ocucaje, como las figuras entrelazadas de felinos o bandas con cabezas radiadas del tipo «hebras retorcidas» (Frame 1991) en sentido S o Z (Figura 5b). El estilo lineal 1 empieza a aparecer en ciertas telas de tocado: por ejemplo, cuando forman parte de un juego de vestimenta. El estilo lineal 2, antes restringido a las telas de tocado, aparece también en las túnicas y también puede aparecer con un fondo verde o azul-púrpura y con el mismo festón anillado típico de otras prendas (Peters 2014).

Un estilo diagnóstico de la fase 1A lleva franjas con el color de fondo en secciones cuadradas alternando los cuatro colores más recurrentes de la fase 10: un rojo «sangre» mediano, un amarillo «oro»" profundo, un verde "cochayuyo» oscuro y un azul «marino» oscuro (v.g. Figura 4c). Este estilo de franja bordada aparece repentinamente en todos los fardos masculinos de la fase 1A, asociado a figuras alternando los mismos colores en los varios estilos bloc-color presentes en esta fase. Posibles antecedentes a nivel de diseño incluyen el aspecto de franjas de estilo línea-ancha o guardillas interiores del estilo mosaico, donde el color predominante de cada figura se percibe de lejos como un cuadro de este color, o las telas policromas de bandas en tela doble de la transición Paracas-Nasca más al sur, como el manto hallado en Cahuachi (Orefici y Drusini 2003: 154, fig. 44; Frame 2009, 209-210) o los fragmentos publicados por Bird y Bellinger (1954). 
Tabla 7. Distribución de formas de manto y vestido entre los contextos estudiados y la muestra comparativa

\begin{tabular}{|c|c|c|c|c|c|c|c|c|}
\hline Formas & Características & $10 \mathrm{~A}(\mathrm{M})$ & $10(\mathrm{~F})$ & $10 \mathrm{~B}(\mathrm{M})$ & $1 \mathrm{~A}(\mathrm{M})$ & $1(\mathrm{~F})$ & $1 \mathrm{~B}(\mathrm{M})$ & $2(\mathrm{M})$ \\
\hline Manto 1a & $\begin{array}{l}\text { Tela llana ( } 2 \text { paños cosidos), } \\
2 \text { bandas tejidas cosidas a los } \\
\text { márgenes laterales, cubiertas } \\
\text { por bordados que se extienden } \\
\text { en parte de los extremos [ ] con } \\
\text { un festón anillado monocromo } \\
\text { y flecos retorcidos; a veces lleva } \\
\text { figuras en el campo central }\end{array}$ & $\begin{array}{c}\text { WK } \\
114, \\
\text { WK } \\
136, \\
\text { WK } \\
147, \\
\text { WK } \\
199, \\
\text { WK } \\
381\end{array}$ & & $\begin{array}{l}\text { WK } 35 \text {, } \\
\text { WK } 157\end{array}$ & $\begin{array}{l}\text { WK 49, WK } \\
91, \text { WK } 94 \\
\text { WK } 292 \\
(190), \text { WK } \\
421\end{array}$ & & $\begin{array}{c}\text { WK } 12(382) \text {, } \\
\text { WK } 38, \text { WK } \\
188\end{array}$ & $\begin{array}{c}\text { WK } \\
253, \\
\text { WK } \\
318 \\
\text { WK } 319\end{array}$ \\
\hline Manto $1 \mathrm{~b}$ & $\begin{array}{l}\text { Tela llana ( } 1 \text { o } 2 \text { pańos cosidos), } \\
2 \text { bandas tejidas cosidas a los } \\
\text { márgenes laterales, cubiertas por } \\
\text { bordados que se extienden en los } \\
\text { extremos [ ], un festón anillado } \\
\text { con figuritas y flecos retorcidos } \\
\text { o anillados; con frecuencia lleva } \\
\text { figuras en el campo central }\end{array}$ & & & $\begin{array}{l}\text { WK } 35 \text {, } \\
\text { WK } 157\end{array}$ & $\begin{array}{l}\text { WK } 91, \text { WK } \\
94, \text { WK } 217, \\
\text { WK } 292 \\
(190), \text { WK } \\
421, \text { WK } \\
438\end{array}$ & & $\begin{array}{l}\text { AB 157, WK } \\
\text { 4, WK } 12 \\
\text { (382), WK 38, } \\
\text { WK 89; WK } \\
\text { 188; WK 262, } \\
\text { WK 310, WK } \\
\text { 378, WK } 451\end{array}$ & $\begin{array}{l}\text { WK318, } \\
\text { WK } 319\end{array}$ \\
\hline Manto 1c & $\begin{array}{l}\text { Tela llana (número de paños } \\
\text { variable), } 2 \text { bandas tejidas } \\
\text { cosidas a los márgenes laterales, } \\
\text { bordadas con figuras o cubiertas } \\
\text { por bordados, con un festón } \\
\text { anillado; puede llevar flecos } \\
\text { tejidos y bordados; puede tener } \\
\text { el campo central con figuras o } \\
\text { cubierto por ellas }\end{array}$ & & & & WK 16 & & $\begin{array}{c}\text { WK } 12 \text { (382), } \\
\text { WK } 378\end{array}$ & WK 253 \\
\hline Manto 2 & $\begin{array}{l}\text { Tela llana de dos paños } \\
\text { de algodón, con franjas } \\
\text { relativamente angostas bordadas } \\
\text { directamente a la tela base [sin } \\
\text { flecos] }\end{array}$ & $\begin{array}{l}\text { WK } \\
114, \\
\text { WK } \\
136\end{array}$ & $\begin{array}{l}\text { WK } \\
113\end{array}$ & $\begin{array}{l}\text { WK } 157, \\
\text { WK } 352\end{array}$ & & $\begin{array}{l}\text { WK } \\
28\end{array}$ & & \\
\hline Manto 3a & $\begin{array}{l}\text { Tela llana ( } 2 \text { pańos cosidos) con } \\
\text { una banda anillada que tapa } \\
\text { la unión entre los pańos de la } \\
\text { tela central, } 2 \text { bandas tejidas } \\
\text { cosidas a los márgenes laterales, } \\
\text { cubiertas por bordados }\end{array}$ & & & & $\begin{array}{c}\text { WK 16, WK } \\
24, \text { WK } 49 \text {, } \\
\text { WK } 217 \text {, } \\
\text { WK } 243\end{array}$ & & & \\
\hline Manto 3b & $\begin{array}{l}\text { Tela llana ( } 2 \text { paños) con una } \\
\text { banda tejida al medio en } \\
\text { sentido longitudinal, bordada, } \\
\text { y } 2 \text { bandas tejidas cosidas a los } \\
\text { márgenes laterales, cubiertas por } \\
\text { bordados que se extienden [ ] }\end{array}$ & & & & & & $\begin{array}{l}\text { WK } 27, \text { WK } \\
38, \text { WK } 378\end{array}$ & $\begin{array}{c}\text { WK } \\
253, \\
\text { WK } \\
298 \\
\text { WK } 319\end{array}$ \\
\hline Manto 3c & $\begin{array}{l}\text { Tela llana, } 2 \text { paños cosidos a una } \\
\text { banda que se extiende al medio } \\
\text { en sentido longitudinal, cubierta } \\
\text { por bordados, con flecaduras en } \\
\text { los márgenes laterales }\end{array}$ & & & & & & $\begin{array}{c}\text { WK } 89, \text { WK } \\
451\end{array}$ & \\
\hline
\end{tabular}


Tabla 7. Distribución de formas de manto y vestido entre los contextos estudiados y la muestra comparativa

\begin{tabular}{|c|c|c|c|c|c|c|c|c|}
\hline Formas & Características & $10 \mathrm{~A}(\mathrm{M})$ & $10(\mathrm{~F})$ & $10 \mathrm{~B}(\mathrm{M})$ & $1 \mathrm{~A}(\mathrm{M})$ & $1(\mathrm{~F})$ & $1 \mathrm{~B}(\mathrm{M})$ & $2(\mathrm{M})$ \\
\hline $\begin{array}{l}\text { Manto } 4 \\
\text { (vestido) }\end{array}$ & $\begin{array}{l}\text { Tela llana, } 2 \text { paños, franjas } \\
\text { laterales de bandas faz de } \\
\text { urdimbre con un diseño listado }\end{array}$ & & $\begin{array}{l}\text { WK } \\
437\end{array}$ & & & $\begin{array}{c}\text { WK } \\
1, \\
\text { WK } \\
28, \\
\text { WK } \\
234, \\
\text { WK } \\
326\end{array}$ & & \\
\hline $\begin{array}{l}\text { Manto 5 } \\
\text { (manto } \\
\text { femenino) }\end{array}$ & $\begin{array}{l}\text { Manto pequeńo con franjas } \\
\text { laterales y bandas transversales, } \\
\text { un par de bandas mas anchas } \\
\text { marcando el centro, sin flecos }\end{array}$ & & & & & $\begin{array}{l}\text { WK } \\
1, \\
\text { WK } \\
28, \\
\text { WK } \\
234, \\
\text { WK } \\
326\end{array}$ & & \\
\hline Manto 6 & $\begin{array}{l}\text { Tela llana variable, con } 2 \text { paños } \\
\text { de colores contrastantes y } \\
\text { franjas tejidas sobrepuestas en } \\
\text { los márgenes laterales; otras } \\
\text { técnicas pueden estar presentes, } \\
\text { por ejemplo teñido con amarre, } \\
\text { bordados o pintura }\end{array}$ & & & & $\begin{array}{c}\text { WK 91, WK } \\
364\end{array}$ & & $\begin{array}{c}\text { WK 188; WK } \\
190(290) \\
\text { WK } 310\end{array}$ & \\
\hline Manto 6a & $\begin{array}{l}\text { Tela llana de camélido con } \\
\text { múltiples bandas de colores } \\
\text { contrastantes, y franjas tejidas } \\
\text { sobrepuestas en los márgenes } \\
\text { laterales }\end{array}$ & & & & & & $\begin{array}{c}\text { WK 27, WK } \\
378\end{array}$ & \\
\hline Manto 6b & $\begin{array}{l}\text { Tela llana variable, } 2 \text { pańos, } \\
\text { con figuras bordadas en hilo } \\
\text { relativamente grueso, y franjas } \\
\text { tejidas sobrepuestas en los } \\
\text { márgenes laterales }\end{array}$ & & & & & & $\begin{array}{l}\text { WK } 12 \text { (382), } \\
\text { WK } 190 \text { (290) }\end{array}$ & \\
\hline $\begin{array}{l}\text { Manto 7 } \\
\text { (anako o } \\
\text { mantón) }\end{array}$ & $\begin{array}{l}\text { Manto corto con franjas } \\
\text { bordadas en los cuatro } \\
\text { márgenes; flecaduras distintas } \\
\text { en los márgenes laterales y del } \\
\text { extremo }\end{array}$ & & & & & & $\begin{array}{l}\text { WK 38, WK } \\
89, \text { WK } 378\end{array}$ & $\begin{array}{c}\text { WK } \\
253 \\
\text { WK } 319\end{array}$ \\
\hline
\end{tabular}


Tabla 8. Distribución de formas de tela de tocado entre los contextos estudiados y la muestra comparativa

\begin{tabular}{|c|c|c|c|c|c|c|c|c|}
\hline Formas & Características & $10 \mathrm{~A}(\mathrm{M})$ & $10(\mathrm{~F})$ & $10 \mathrm{~B}(\mathrm{M})$ & $1 \mathrm{~A}(\mathrm{M})$ & $1(\mathrm{~F})$ & $1 \mathrm{~B}(\mathrm{M})$ & 2 \\
\hline $\begin{array}{l}\text { Turbante 1a } \\
\text { (ñañaka) }\end{array}$ & $\begin{array}{l}\text { Tela llana de baja densidad } \\
\text { (título bajo) con un hilado } \\
\text { fino de tensión fuerte (crepe), } \\
\text { dos pańos, aprox. } 2 \text { m de } \\
\text { largo, bordados de estilo } \\
\text { Lineal } 2\end{array}$ & $\begin{array}{l}\text { WK } 114, \\
\text { WK } 136, \\
\text { WK } 147, \\
\text { WK } 381\end{array}$ & WK 437 & $\begin{array}{l}\text { WK } 157, \\
\text { WK } 352\end{array}$ & $\begin{array}{l}\text { WK 16, } \\
\text { WK 24, } \\
\text { WK 26, } \\
\text { WK 49, } \\
\text { WK 91, } \\
\text { WK 94, } \\
\text { WK 243, } \\
\text { WK 292 } \\
(190), \text { WK } \\
217, \text { WK } \\
421, \text { WK } \\
438\end{array}$ & $\begin{array}{l}\text { WK } 1, \\
\text { WK 28, } \\
\text { WK 234, } \\
\text { WK 326, } \\
\text { WK } 382 \\
(12)\end{array}$ & $\begin{array}{l}\text { WK } 12 \\
(382)\end{array}$ & \\
\hline $\begin{array}{l}\text { Turbante } 1 \mathrm{~b} \\
\text { (ñañaka) }\end{array}$ & $\begin{array}{l}\text { Tela llana de mediana } \\
\text { densidad, dos pańos, aprox. } \\
2 \mathrm{~m} \text { de largo, bordados } \\
\text { de estilo Lineal 1c o } \\
\text { Linea-Ancha }\end{array}$ & & & $\begin{array}{l}\text { WK } 49 \text {, } \\
\text { WK } 157\end{array}$ & $\begin{array}{l}\text { WK } 243 \text {, } \\
\text { WK } 292 \\
(190), \text { WK } \\
421\end{array}$ & & $\begin{array}{l}\text { WK } 12 \\
(382), \\
\text { WK 310, } \\
\text { WK 378 }\end{array}$ & \\
\hline $\begin{array}{l}\text { Turbante } 2 \\
\text { (ńańaka) }\end{array}$ & $\begin{array}{l}\text { Tela llana de mediana } \\
\text { densidad creada con un } \\
\text { hilado fino de tensión fuerte } \\
\text { (crepe), dos paños más } \\
\text { anchos de aprox. } 2 \mathrm{~m} \text { de } \\
\text { largo, franjas bordadas de } \\
\text { diseño variable }\end{array}$ & & $\begin{array}{l}\text { WK } 113, \\
\text { WK } 149, \\
\text { WK } 437\end{array}$ & WK 352 & & $\begin{array}{l}\text { WK } 28, \\
\text { WK } 326\end{array}$ & & \\
\hline $\begin{array}{l}\text { Turbante } 3 \\
\text { (ńañaka) }\end{array}$ & $\begin{array}{l}\text { Tela llana de algodón o } \\
\text { camélido, más corto, con } \\
\text { franjas de estilo Lineal } 2 \text { o } \\
\text { Bloc-color, flecos retorcidos } \\
\text { o anillados }\end{array}$ & & & & & & $\begin{array}{l}\text { WK } 310, \\
\text { WK 262, } \\
\text { WK } 378\end{array}$ & \\
\hline $\begin{array}{l}\text { Turbante } 4 \\
\text { (ńańaka) }\end{array}$ & $\begin{array}{l}\text { Tela llana larga y angosta, } \\
\text { franjas bordadas rectas } \\
\text { (ancho se aproxima al de la } \\
\text { tela central) }\end{array}$ & & & & $\begin{array}{l}\text { WK } 292 \\
(190)\end{array}$ & & $\begin{array}{l}\text { WK } 89, \\
\text { WK } 190 \\
(290)\end{array}$ & \\
\hline $\begin{array}{l}\text { Turbante } 5 \\
\text { (ńańaka) }\end{array}$ & $\begin{array}{l}\text { Tela llana cuadrangular } \\
\text { doblada en un triángulo, } \\
\text { franja en un margen }\end{array}$ & & & & & & WK 89 & \\
\hline $\begin{array}{l}\text { Turbante } 6 \\
\text { (ńańaka) }\end{array}$ & $\begin{array}{l}\text { Tela llana pequeña, parece } \\
\text { el manto femenino con } \\
\text { franjas laterales y bandas } \\
\text { transversales, pero con flecos }\end{array}$ & & & & & & $\begin{array}{l}\text { WK } 188, \\
\text { WK } 190 \\
(290)\end{array}$ & WK 319 \\
\hline $\begin{array}{l}\text { Turbante } 7 \\
\text { (anako) }\end{array}$ & $\begin{array}{l}\text { Tela llana con franjas } \\
\text { angostas en los cuatro lados, } \\
\text { flecos adyacentes }\end{array}$ & & & & & & $\begin{array}{l}\text { WK } 27, \\
\text { WK } 38 \\
\text { WK } 89 \\
\text { WK } 378 \\
\text { WK } 451\end{array}$ & $\begin{array}{l}\text { WK } 253 \text {, } \\
\text { WK } 318, \\
\text { WK } 319\end{array}$ \\
\hline $\begin{array}{l}\text { Turbante } 8 \\
\text { (ńañaka) }\end{array}$ & $\begin{array}{l}\text { Tela llana con franjas rectas } \\
\text { en los margenes laterales, } \\
\text { flecos, bordados en el } \\
\text { campo central (eg. lineas } \\
\text { escalonadas, cabecitas) }\end{array}$ & & & & & & WK 378 & WK 319 \\
\hline
\end{tabular}


a

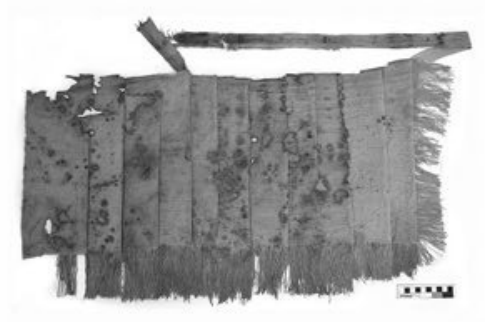

b

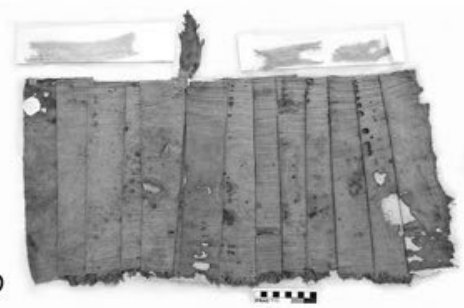

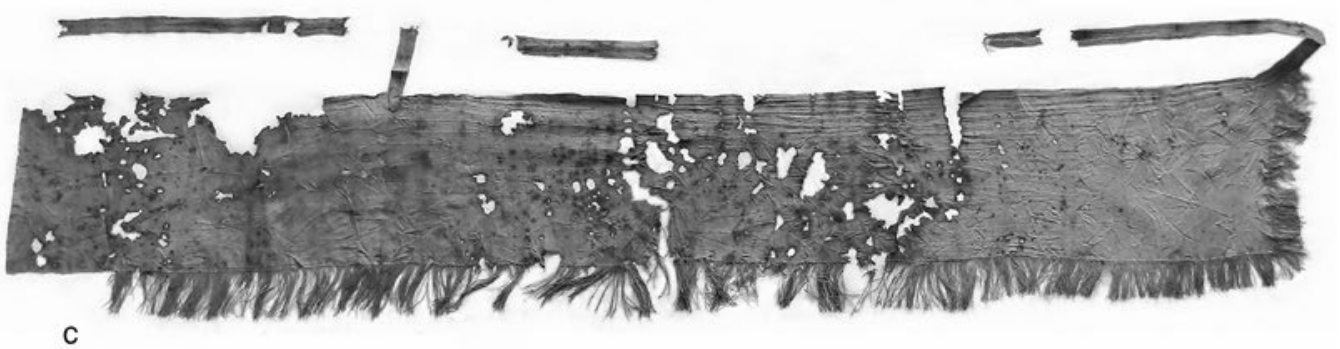
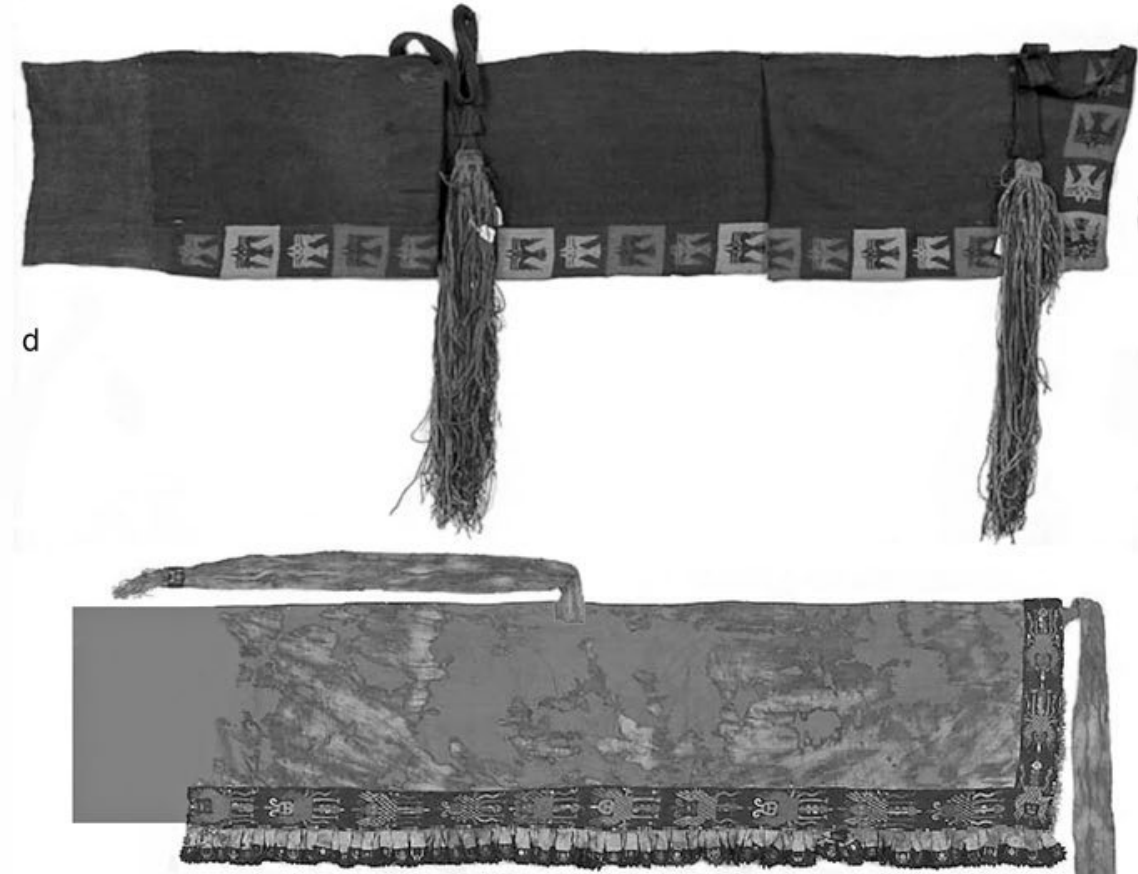

e

Figura 4. Formas de falda predominantes en contextos masculinos de las fases 10 y 1 (A. H. Peters): a. Falda 1, WK 136 espécimen 22, manera en que se encontraba doblada en el fardo (basado en foto de Peters, MRI 2011). b. Falda 1, WK 136 espécimen 35, manera en que se encontraba doblada en el fardo (basado en foto de Peters, MRI 2011). c. Falda 1, WK 136 espécimen 22, extendida (basado en foto de Peters, MRI 2011). d. Falda 2, WK 94 espécimen 47 (basado en foto del proyecto Telefónica, MNAAHP). e. Falda 3, WK 217 espécimen 20, reconstrucción de forma (basado en foto del proyecto Telefónica, MNAAHP). 
Tabla 9. Distribución de cuerdas, hondas y bandas entre los contextos estudiados y la muestra comparativa

\begin{tabular}{|c|c|c|c|c|c|c|c|c|}
\hline Formas & Características & $10 \mathrm{~A}(\mathrm{M})$ & $10(\mathrm{~F})$ & 10B (M) & $1 \mathrm{~A}(\mathrm{M})$ & $1(\mathrm{~F})$ & 1B (M) & 2 \\
\hline Cuerda 1 & $\begin{array}{l}\text { Cuerda gruesa retorcida } \\
\text { compuesta de hilos de dos o } \\
\text { más colores }\end{array}$ & & $\begin{array}{l}\text { WK } 113 \text {, } \\
\text { WK } 149 \text {, } \\
\text { WK } 437\end{array}$ & & & $\begin{array}{l}\text { WK 234, } \\
\text { WK 326, } \\
\text { WK382 } \\
\text { (fardo 12) }\end{array}$ & & \\
\hline $\begin{array}{l}\text { Honda } \\
\text { (waraka) }\end{array}$ & $\begin{array}{l}\text { Cuerda trenzada de fibra de } \\
\text { maguey con un anillo de } \\
\text { dedo, una canasta de cuerdas } \\
\text { interconectadas y una borla }\end{array}$ & $\begin{array}{l}\text { Cat99 t.2, } \\
\text { WK } 114, \\
\text { WK } 147, \\
\text { WK } 199\end{array}$ & & $\begin{array}{l}\text { WK } 35 \text {, } \\
\text { WK } 49 \text {, } \\
\text { WK } 157\end{array}$ & $\begin{array}{l}\text { WK 16, } \\
\text { WK 91, } \\
\text { WK 94, } \\
\text { WK 217, } \\
\text { WK 243, } \\
\text { WK } 292 \\
(190) \text {, } \\
\text { WK 421, } \\
\text { WK } 438\end{array}$ & & $\begin{array}{l}\text { WK 4, } \\
\text { WK } 12 \\
(382), \\
\text { WK 27, } \\
\text { WK 89, } \\
\text { WK } 190 \\
(290), \\
\text { WK 262, } \\
\text { WK 310, } \\
\text { WK 451 }\end{array}$ & WK 253 \\
\hline $\begin{array}{l}\text { Honda } \\
\text { elementos }\end{array}$ & $\begin{array}{l}\text { Adorno hecho de elementos de } \\
\text { honda, e.g. canasta o borla, en } \\
\text { fibra de maguey }\end{array}$ & & & & WK 217 & & $\begin{array}{l}\text { WK 4, } \\
\text { WK } 190 \\
\text { (fardo 290), } \\
\text { WK } 310\end{array}$ & WK 253 \\
\hline $\begin{array}{l}\text { Banda 1a } \\
\text { (llauto) }\end{array}$ & $\begin{array}{l}\text { Banda angosta urdimbre- } \\
\text { dominante con urdimbres } \\
\text { suplementarias }\end{array}$ & WK 110 & & & & & & \\
\hline Banda $1 b$ & $\begin{array}{l}\text { Banda ancha urdimbre- } \\
\text { dominante con urdimbres } \\
\text { suplementarias, dos capas } \\
\text { cosidas y una flecadura con } \\
\text { tapa anillada }\end{array}$ & & WK 113 & & & & & \\
\hline Banda 1c & $\begin{array}{l}\text { Banda urdimbre-dominante } \\
\text { con patrón listado (parecido a } \\
\text { franja de vestido) }\end{array}$ & & & & & WK 326 & & \\
\hline $\begin{array}{l}\text { Banda 2a } \\
\text { (llauto) }\end{array}$ & $\begin{array}{l}\text { Panel anudado angosto con } \\
\text { paneles laterales en entrelazado } \\
\text { diagonal complejo, tapiz } \\
\text { modificado, flecadura larga }\end{array}$ & WK 114 & & & & & & \\
\hline $\begin{array}{l}\text { Banda 2b } \\
\text { (llauto) }\end{array}$ & $\begin{array}{l}\text { Panel anudado ancho con } \\
\text { paneles laterales en entrelazado } \\
\text { diagonal complejo, tapiz } \\
\text { modificado, flecadura larga }\end{array}$ & $\begin{array}{l}\text { WK } 114, \\
\text { WK } 199\end{array}$ & & $\begin{array}{l}\text { WK 49, } \\
\text { WK } 352\end{array}$ & WK 49 & & & \\
\hline $\begin{array}{l}\text { Banda 3a } \\
\text { (llauto) }\end{array}$ & $\begin{array}{l}\text { Anillado tubular con } 2-3 \\
\text { 'dedos' tubulares al extremo }\end{array}$ & $\begin{array}{l}\text { WK } 136, \\
\text { WK } 114, \\
\text { WK } 381\end{array}$ & & & & & & \\
\hline $\begin{array}{l}\text { Banda 3b } \\
\text { (llauto) }\end{array}$ & $\begin{array}{l}\text { Anillado tubular plano con 4-6 } \\
\text { 'dedos' tubulares al extremo }\end{array}$ & & & & WK 421 & & $\begin{array}{l}\text { WK } 12 \\
(382) \\
\text { WK } 262\end{array}$ & \\
\hline $\begin{array}{l}\text { Banda 4a } \\
\text { (llauto) }\end{array}$ & $\begin{array}{l}\text { Banda de enlace de pares de } \\
\text { hilos en sentido diagonal }\end{array}$ & Cat99t2 & & & $\begin{array}{l}\text { WK } 16, \\
\text { WK } 26\end{array}$ & & & \\
\hline $\begin{array}{l}\text { Banda 4b } \\
\text { (llauto) }\end{array}$ & $\begin{array}{l}\text { Banda de enlace de pares de } \\
\text { hilos en sentido diagonal, con } \\
\text { secciones de hilos en colores } \\
\text { contrastantes agrupados que } \\
\text { crean un imagen 'trenzado' }\end{array}$ & & & & $\begin{array}{l}\text { WK } 16, \\
\text { WK } 91, \\
\text { WK } 243 \text {, } \\
\text { WK } 364, \\
\text { WK } 421\end{array}$ & & $\begin{array}{l}\text { WK } 12 \\
(382) \text {, } \\
\text { WK 38, } \\
\text { WK 89, } \\
\text { WK } 190 \\
(290)\end{array}$ & \\
\hline
\end{tabular}


Tabla 9. Distribución de cuerdas, hondas y bandas entre los contextos estudiados y la muestra comparativa

\begin{tabular}{|c|c|c|c|c|c|c|c|c|}
\hline Formas & Características & $10 \mathrm{~A}(\mathrm{M})$ & $10(\mathrm{~F})$ & $10 \mathrm{~B}(\mathrm{M})$ & $1 \mathrm{~A}(\mathrm{M})$ & $1(\mathrm{~F})$ & $1 \mathrm{~B}(\mathrm{M})$ & 2 \\
\hline $\begin{array}{l}\text { Banda 4c } \\
\text { (llauto) }\end{array}$ & $\begin{array}{l}\text { Banda de enlace de pares de } \\
\text { hilos en sentido diagonal, } \\
\text { dominado por secciones de } \\
\text { hilos agrupados que crean } \\
\text { imágenes de cuerdas trenzadas } \\
\text { o retorcidas }\end{array}$ & & & & & & $\begin{array}{l}\text { WK 23, } \\
\text { WK 38, } \\
\text { WK 298, } \\
\text { WK 319, } \\
\text { WK 451 }\end{array}$ & $\begin{array}{l}\text { WK } 298 \text {, } \\
\text { WK } 319\end{array}$ \\
\hline $\begin{array}{l}\text { Banda 4d } \\
\text { (llauto) }\end{array}$ & $\begin{array}{l}\text { Enlace diagonal de grupos de } \\
\text { hilos en colores contrastantes } \\
\text { que cubren la superficie } \\
\text { creando imágnes de cuerdas }\end{array}$ & & & & & & WK 38 & $\begin{array}{l}\text { WK } 253 \text {, } \\
\text { WK } 298, \\
\text { WK } 318, \\
\text { WK } 319\end{array}$ \\
\hline $\begin{array}{l}\text { Banda } 5 \\
\text { (llauto) }\end{array}$ & $\begin{array}{l}\text { Banda tejida en faz de trama } \\
\text { con figuras en tapiz ranurado }\end{array}$ & & & & WK 217 & & $\begin{array}{l}\text { WK } 38, \\
\text { WK } 89\end{array}$ & \\
\hline $\begin{array}{l}\text { Banda } 6 \\
\text { (cinta) }\end{array}$ & $\begin{array}{l}\text { Bandas angostas de enlace } \\
\text { diagonal de hilos de maguey } \\
\text { con amarre de hilos de camelido } \\
\text { en colores contrastantes }\end{array}$ & & & & & & $\begin{array}{l}\text { WK } 4 \\
\text { WK } 190 \\
(290) \\
\text { WK } 310\end{array}$ & $\begin{array}{l}\text { WK } 253 \text {, } \\
\text { WK } 318 \text {, } \\
\text { WK } 319\end{array}$ \\
\hline
\end{tabular}

Tabla 10. Distribución de bolsas, canastos y otros contenedores entre los contextos estudiados y la muestra comparativa

\begin{tabular}{|c|c|c|c|c|c|c|c|c|}
\hline Elemento & Características & $10 \mathrm{~A}(\mathrm{M})$ & $10(\mathrm{~F})$ & $10 \mathrm{~B}(\mathrm{M})$ & $1 \mathrm{~A}(\mathrm{M})$ & $1(\mathrm{~F})$ & $1 \mathrm{~B}(\mathrm{M})$ & $2(\mathrm{M})$ \\
\hline Bolsa 1 & $\begin{array}{l}\text { Tela llana faz de urdimbre } \\
\text { listada, doblada y cosida } \\
\text { como bolsa }\end{array}$ & & WK 149 & WK 49 & & $\begin{array}{l}\text { WK 326, } \\
\text { WK } 382 \text { (12) }\end{array}$ & WK 12 (382) & \\
\hline Bolsa 2 & $\begin{array}{l}\text { Entrelazado diagonal en } \\
\text { dos pańos homólogos, de la } \\
\text { técnica 'sprang' }\end{array}$ & & & WK 49 & WK 16 & WK 382 (12) & & \\
\hline $\begin{array}{l}\text { Canasto } \\
\text { cosido }\end{array}$ & $\begin{array}{l}\text { Canasto grande de } \\
\text { elementos unidos en un } \\
\text { rollo grueso, cosido en } \\
\text { espiral }\end{array}$ & & & WK 157 & $\begin{array}{l}\text { WK 16, } \\
\text { WK 91, } \\
\text { WK 94, } \\
\text { WK 217, } \\
\text { WK 401, } \\
\text { WK 421 }\end{array}$ & WK 28 & $\begin{array}{c}\text { AB 157, } \\
\text { WK } 12 \text { (382), } \\
\text { WK 38, } \\
\text { WK 89, } \\
\text { WK 190 } \\
(290), \\
\text { WK 310, } \\
\text { WK 323, } \\
\text { WK 378, } \\
\text { WK 451 }\end{array}$ & $\begin{array}{l}\text { WK } 253 \\
\text { WK } 319\end{array}$ \\
\hline $\begin{array}{l}\text { Canasto } \\
\text { torzal }\end{array}$ & $\begin{array}{l}\text { Canasto mediano a } \\
\text { grande fabricado por } \\
\text { dos elementos retorcidos } \\
\text { alrededor de una serie de } \\
\text { elementos radiantes. }\end{array}$ & & & & WK 16 & & WK 378 & \\
\hline $\begin{array}{l}\text { Anillo de } \\
\text { juncos }\end{array}$ & $\begin{array}{l}\text { Masa de tallos vegetales en } \\
\text { forma anular en la } 2 \text { da capa } \\
\text { alrededor del individuo }\end{array}$ & & & & & & WK 27 & \\
\hline $\begin{array}{l}\text { Piel de } \\
\text { venado }\end{array}$ & $\begin{array}{l}\text { Piel de venado con pelo, } \\
\text { alrededor del individuo }\end{array}$ & & & & & & $\begin{array}{l}\text { WK } 12 \text { (382), } \\
\text { WK 38, } \\
\text { WK 310, } \\
\text { WK 451 }\end{array}$ & \\
\hline
\end{tabular}



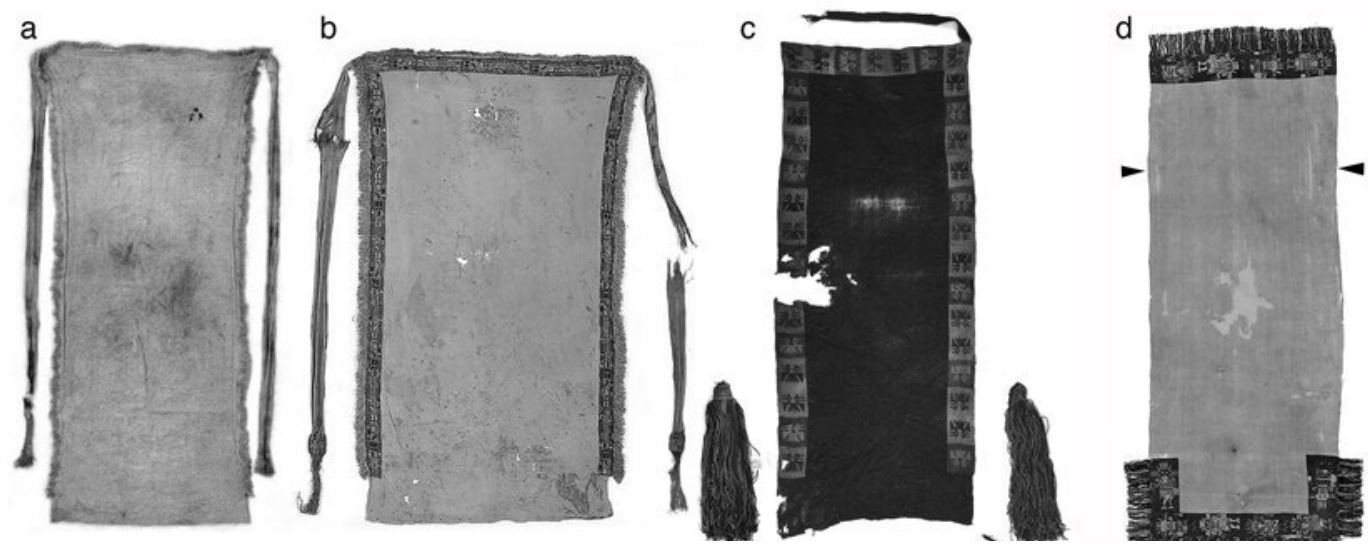

Figura 5. Formas de wara predominantes en contextos masculinos de la fase 1 (A. H. Peters): a. Wara 1a, WK 91 espécimen 63 (basado en foto del proyecto Telefónica, MNAAHP). b. Wara 1b, WK 91 espécimen 30 (basado en foto del proyecto Telefónica, MNAAHP). c. Wara 2, WK 364 espécimen 16, con las tiras incompletas (basado en foto de Peters, 2012). d. Wara 3, WK 310 espécimen 43, con las tiras ausentes indicadas por flechas (basado en foto del proyecto Telefónica, MNAAHP).

Estilos atípicos ocurren en la mayoría de los fardos complejos y la mayoría muestran características diagnósticas de nuestra definición de Nasca 1 (Peters 2017b), por ejemplo figuras bordadas en una franja tejida (presentes en WK 16, WK 378, WK 420), múltiples figuras diferentes tipo "guerrero» alineadas en el mismo sentido (sin alternar direccionalidad) y colores consistentes motivados por un color del objeto representado (por ejemplo, los ojos en blanco y negro, el cabello negro, las plumas blancas del cóndor) ${ }^{4}$. El contexto WK 292 (fardo 190: Tabla 12) se caracteriza por la presencia de muchos elementos de traje con estas características. Estos artefactos indican relaciones de intercambio e influencia con otros productores de bordados complejos, y entre ellos también hay diversidad de estilos. En resumen, no existe un solo Nasca 1; sería importante trazar todos los sitios asociados a textiles con estas características.

Los fardos femeninos de la fase 1 se caracterizan por una serie de elementos de indumentaria bien definidos. Esta indumentaria se observó por primera vez en el fardo complejo WK 28, abierto en 1930, y el vestido femenino (manto 4) fue denominado como tal en la apertura de otros fardos en esa misma década. Se constituye por dos paños de tela llana de algodón natural o de camélido teñido, con bandas tejidas cosidas a los márgenes laterales (Figura 8d). Estas franjas se han tejido en faz urdimbre-dominante, con urdimbres en los cuatro colores típicos formando patrones listados, frecuentemente con bandas en "peinecillo» creadas al alternar dos colores al urdir. Posiblemente estas franjas han sido reutilizadas en varios vestidos, porque sus medidas a veces no corresponden a las del par o de la tela central. El vestido aparece en forma miniatura en WK 326 y WK 382 (fardo 12: Tabla 12) asociado a la cuerda gruesa policroma, lo que demuestra sus roles como símbolos de la vestimenta femenina.

El manto femenino (manto 5) en esta fase se caracteriza también por un diseño bien definido: más pequeño que los otros mantos, lleva franjas laterales con una guardilla interior y bandas transversales, las que incluyen dos bandas centrales más anchas que dividen el manto en dos mitades. (Figuras $8 \mathrm{~b}$ y $8 \mathrm{c}$ ) Los fardos femeninos de la fase 1 suelen incluir también telas bordadas parecidas al Manto 2 y telas de tocado variadas. En WK 28, telas con franjas bordadas en estilo lineal 2 han sido colocadas encima de una serie de telas de tocado, predominantemente turbante 2 , con bordados de estilo Bloc-color cuyos hilados, colores y figuras se parecen a los bordados de la fase 1B. Esta práctica de cubrir ofrendas más novedosas o más relacionadas a Nasca con vestimenta más 

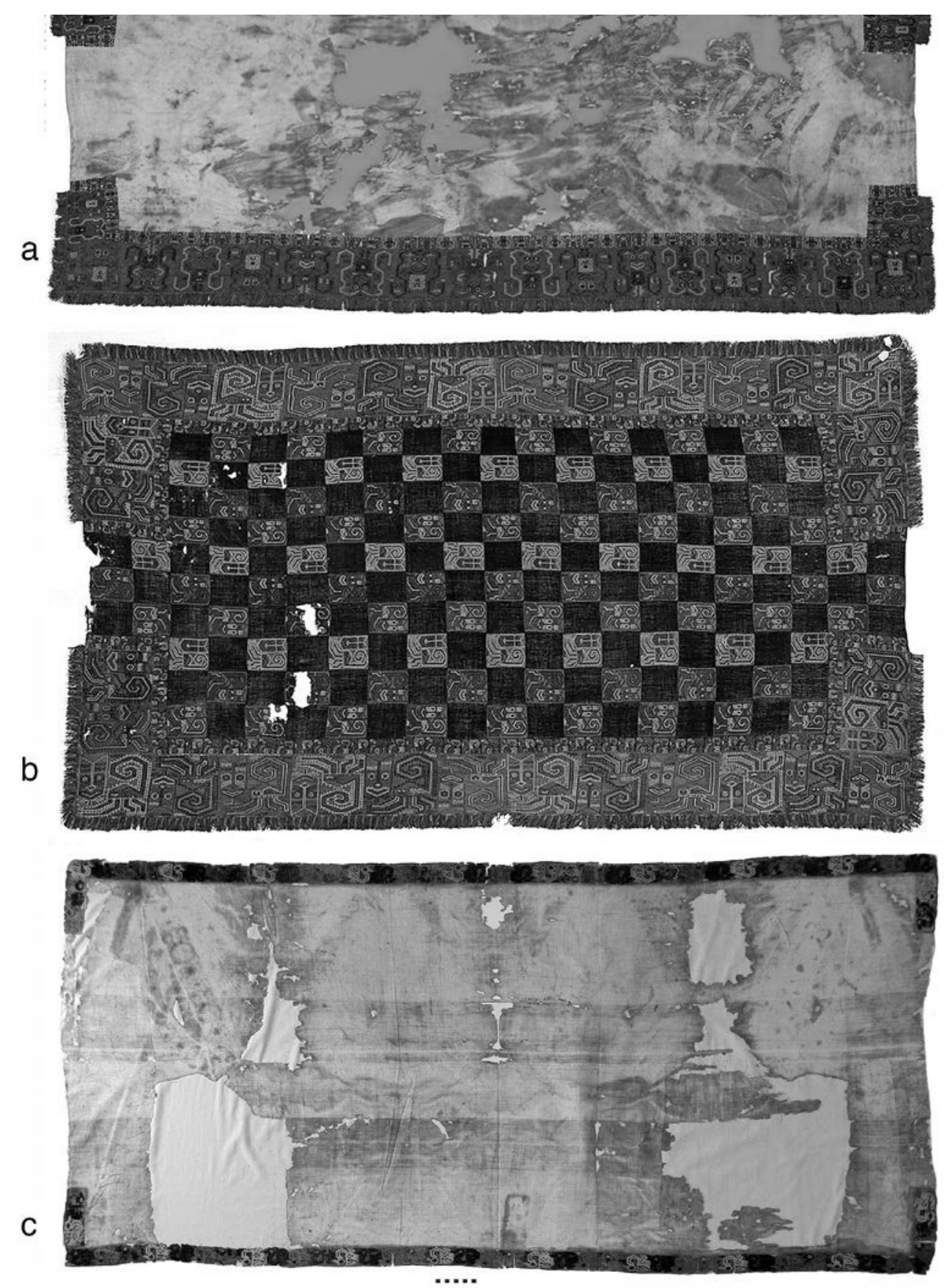

Figura 6. Formas de manto presentes en contextos de la fase 10, transicionales y de la fase $1 \mathrm{~A}$ (A. H. Peters): a. Manto 1a, WK 157 espécimen 50 (basado en foto del proyecto Telefónica, MNAAHP). b. Manto 1b, WK 292 espécimen 7 (basado en foto del proyecto Telefónica, MNAAHP). c. Manto 2, WK 352 espécimen 35 (40) (basado en foto de Peters, MRI 2011). 
antigua o tradicional se nota en todos los fardos estudiados cuyos niveles de conservación y documentación permiten este tipo de observaciones.

Hay varias formas de bolsa asociadas a fardos masculinos y femeninos de la fase 1 (Tabla 10). Bolsas de tela urdimbre-dominante con listas y peinecillo (bolsa 1) han sido documentadas en los fardos masculinos WK 49 y WK 12 (fardo 382) y los femeninos WK 149, WK 326 y WK 382 (fardo 12). Una bolsa creada en entrelazado diagonal (bolsa 2) por la técnica sprang (Emery 1994) ha sido conservada en WK 16, WK 49 y WK 382 (fardo 12), donde ha sido recreada también en miniatura. Una bolsa de tela llana con franjas y listas bordadas, parecida a la mitad de un manto femenino doblada, con borlas en las esquinas y una cuerda cerrando la abertura, estaba colocada en la nuca del individuo masculino en WK 16. Estos contenedores compartidos por hombres y mujeres caracterizan los fardos de la fase 1 y ciertos fardos transicionales. Los canastos funerarios grandes y sólidos, construidos con anillos de nervadura de hojas de cańa cosidas con junco, también aparecen por primera vez en los fardos transicionales y son típicos de los fardos complejos de las fases 1 y 2 . WK 28 es la única mujer identificada hasta el momento asociada a este tipo de canasto. El cuerpo del difunto se coloca en este canasto en la segunda fase de ritos post mortem.

La mayoría de los fardos publicados (Tello 1959; Paul 1990, 1991; Aponte 2006; Thays 2016) y los artefactos exhibidos corresponden a la fase 1B y por lo mismo se han llegado a considerar los más representativos de Paracas Necrópolis. Sin embargo, estos estilos relacionados con Nasca representan un momento histórico posterior a la transición Paracas-Nasca, si bien a la vez siguen representando circunstancias de diversidad e interacción socioculturales. No existe una distinción fuerte en las prácticas mortuorias asociadas a las fases $1 \mathrm{~A}, 1 \mathrm{~B}$ y 2 , sino una serie de innovaciones en la forma de los artefactos, los estilos de bordado y las otras técnicas y materiales presentes, que aparecen distribuidas entre los fardos en un patrón complejo. Cada fardo se caracteriza por estilos recurrentes (aquí denominados estilos «de casa»), otros estilos que lo ligan a otros fardos de Paracas Necrópolis (denominados estilos «de visita») y por ciertos estilos atípicos de Paracas Necrópolis (denominados estilos «de otros»).

Tabla 11. Distribución de tipos de túnica denominados «casulla» entre los contextos estudiados y la muestra comparativa

\begin{tabular}{|c|c|c|c|c|c|c|c|c|}
\hline Formas & Caracteristicas & $10 \mathrm{~A}(\mathrm{M})$ & $10(\mathrm{~F})$ & $10 \mathrm{~B}(\mathrm{M})$ & $1 \mathrm{~A}(\mathrm{M})$ & $1(\mathrm{~F})$ & $1 \mathrm{~B}(\mathrm{M})$ & $2(\mathrm{M})$ \\
\hline Casulla 1 & $\begin{array}{l}\text { Túnica abierta con } 1 \text { o } 2 \text { paneles } \\
\text { de piel curtida, con flecos } \\
\text { rectangulares }\end{array}$ & $\begin{array}{l}\text { WK } 114^{*} \text {, } \\
\text { WK 352* }\end{array}$ & & & $\begin{array}{l}\text { WK } 217 \text {, } \\
\text { WK } 438\end{array}$ & & $\begin{array}{l}\text { WK } 12 \text { (382), } \\
\text { WK 27, } \\
\text { WK 262, } \\
\text { WK 310, } \\
\text { WK 323, } \\
\text { WK } 378\end{array}$ & $\begin{array}{l}\text { WK } 298 \text {, } \\
\text { WK } 319\end{array}$ \\
\hline Casulla 2 & $\begin{array}{l}\text { Paño de algodón cubierto con } \\
\text { hileras de plumas amarillas } \\
\left({ }^{* *} \text { variante, plumas de cóndor) }\right.\end{array}$ & & & & & & $\begin{array}{l}\text { **WK } 190 \\
(290) \\
\text { WK } 310\end{array}$ & $\begin{array}{l}\text { WK } 253 \text {, } \\
\text { WK } 319\end{array}$ \\
\hline Casulla 3 & $\begin{array}{l}\text { Tela de camélido azul marino } \\
\text { con abertura horizontal; } \\
\text { generalmente adornada con } \\
\text { hileras de plumas amarillas }\end{array}$ & & & & WK 94 & & $\begin{array}{l}\text { AB 157, } \\
\text { WK 38, } \\
\text { WK 94, } \\
\text { WK 253, } \\
\text { WK 451 }\end{array}$ & \\
\hline Casulla 4 & Paño de algodón pintado & & & & & & $\begin{array}{l}\text { WK 23, } \\
\text { WK } 190 \\
(290)\end{array}$ & \\
\hline
\end{tabular}

* Identificación tentativa basada en restos muy fragmentarios 
Tabla 12. Cambios de numeración de los fardos del cementerio de Wari Kayan en los estudios posteriores, los que afectan el registro de sus objetos asociados en las colecciones del MNAAHP y su designación en las publicaciones

\begin{tabular}{|c|c|c|c|c|c|}
\hline $\begin{array}{l}\mathrm{N}^{\circ} \text { del } \\
\text { cuaderno de } \\
\text { campo }\end{array}$ & $\begin{array}{c}\mathrm{N}^{\circ} \text { del } \\
\text { inventario }\end{array}$ & $\begin{array}{l}\mathrm{N}^{\circ} \text { designado } \\
\text { en la apertura } \\
\text { inicial (ańo) }\end{array}$ & $\begin{array}{l}\mathrm{N}^{\circ} \text { designado } \\
\quad \text { en otro } \\
\text { estudio (año) }\end{array}$ & $\begin{array}{l}\text { Motivo aparente } \\
\text { del cambio }\end{array}$ & Evidencia \\
\hline $\begin{array}{l}\text { Wari Kayan } \\
12\end{array}$ & $12 / 5382$ & $\begin{array}{l}\text { Fardo } 382 \\
(1929)\end{array}$ & & $\begin{array}{l}\text { Evitar que ciertos } \\
\text { fardos fuesen a } \\
\text { Sevilla. }\end{array}$ & $\begin{array}{l}\text { Anotación por Toribio Mejía en su copia } \\
\text { del protocolo de apertura y en el inventario } \\
\text { de campo. Los objetos exteriores al fardo } \\
\text { se mantuvieron con los datos de tumba e } \\
\text { inventario originales. }\end{array}$ \\
\hline $\begin{array}{l}\text { Wari Kayan } \\
71\end{array}$ & $12 / 5564$ & $\begin{array}{l}\text { Fardo } 12 \\
(1968)\end{array}$ & & Error de lectura. & $\begin{array}{l}\text { En el protocolo de apertura se discute si el } \\
\text { fardo abierto inicialmente como } 71 \text { debe ser } \\
\text { mas bién el fardo } 12 \text {. Otro fardo "12" había } \\
\text { sido abierto en } 1933 \text {. }\end{array}$ \\
\hline $\begin{array}{l}\text { Wari Kayan } \\
91\end{array}$ & $12 / 5650$ & $\begin{array}{l}\text { Fardo 91 } \\
(1929)\end{array}$ & $\begin{array}{l}\text { Dos mantos } \\
\text { designados } \\
\text { como 364-2 } \\
\text { (11) y } 12 \text { (año } \\
\text { desconocido) }\end{array}$ & $\begin{array}{l}\text { Equivocación por } \\
\text { ausencia de un } \\
\text { número asociado } \\
\text { al textil. }\end{array}$ & $\begin{array}{l}\text { Los mantos } 8 \text { y } 9 \text { no fueron inventariados en la } \\
\text { apertura, pero dos mantos correspondiendo a } \\
\text { estas descripciones fueron luego inventariados } \\
\text { como } 364-2 \text { (u 11) y } 364-12 \text {, números que } \\
\text { corresponden al manto que fue a Sevilla y dos } \\
\text { telas burdas del fardo } 364 \text {. }\end{array}$ \\
\hline $\begin{array}{l}\text { Wari Kayan } \\
157 \text { (o 155?) }\end{array}$ & $12 / 5752$ & $\begin{array}{l}\text { Fardo } 410 \\
(1929)\end{array}$ & $\begin{array}{l}\text { Algunos } \\
\text { textiles están } \\
\text { designados } \\
\text { como } 157 \text { y } \\
\text { otros } 410\end{array}$ & $\begin{array}{l}\text { Evitar que ciertos } \\
\text { fardos fuesen a } \\
\text { Sevilla. }\end{array}$ & $\begin{array}{l}\text { Anotaciones en los inventarios textiles del } \\
\text { MNAA entre 1978-1990. El tamańo del } \\
\text { fardo corresponde a la descripción de Wari } \\
\text { Kayan } 155(\mathrm{X}) \text { y no a } 157(\mathrm{Z}) \text {. Fardo } 155 \text { fue } \\
\text { escogido para Sevilla. }\end{array}$ \\
\hline $\begin{array}{l}\text { Wari Kayan } \\
190\end{array}$ & $12 / 5785$ & $\begin{array}{l}\text { Fardo } 290 \\
(1929)\end{array}$ & & $\begin{array}{l}\text { Evitar que ciertos } \\
\text { fardos fuesen a } \\
\text { Sevilla. }\end{array}$ & $\begin{array}{l}\text { Anotación por Toribio Mejía en su lista de } \\
\text { momias estudiadas y en Tello y Mejía } 1979 . \\
\text { Los objetos exteriores al fardo se mantuvieron } \\
\text { con los datos de tumba e inventario originales. }\end{array}$ \\
\hline $\begin{array}{l}\text { Wari Kayan } \\
203\end{array}$ & $12 / 5798$ & $\begin{array}{l}\text { Sevilla 1, 2, 3, } \\
\text { o 4? }\end{array}$ & $\begin{array}{l}\text { Fardo } 349 \\
\text { especimen } 1\end{array}$ & $\begin{array}{l}\text { Se cambió a “38” } \\
\text { para mandarlo a } \\
\text { Sevilla. }\end{array}$ & $\begin{array}{l}\text { Un manto fue separado del fardo cuando fue } \\
\text { embalado para su traslado al Ministerio de } \\
\text { Relaciones Exteriores en } 1929 \text {, y designado } \\
\text { "349 especimen 1". Corresponde a la } \\
\text { descripción del manto exterior de } 203 \text { - que } \\
\text { fue cambiado por el } 38 \text { - y no del } 349 \text {, que } \\
\text { tuvo pocos textiles conservados. }\end{array}$ \\
\hline $\begin{array}{l}\text { Wari Kayan } \\
292\end{array}$ & $12 / 5950$ & $\begin{array}{l}\text { Fardo } 190 \\
(1929)\end{array}$ & & $\begin{array}{l}\text { Evitar que ciertos } \\
\text { fardos fuesen a } \\
\text { Sevilla. }\end{array}$ & $\begin{array}{l}\text { Anotación por Toribio Mejía en su lista de } \\
\text { momias estudiadas y en Tello y Mejía } 1979 . \\
\text { Los objetos exteriores al fardo se mantuvieron } \\
\text { con los datos de tumba e inventario originales. }\end{array}$ \\
\hline $\begin{array}{l}\text { Wari Kayan } \\
364\end{array}$ & $12 / 6630$ & $\begin{array}{l}\text { Fardo } 364 \\
(1929)\end{array}$ & $\begin{array}{l}\text { Fardo } 23 \\
(1967)\end{array}$ & $\begin{array}{l}\text { Equivocación } \\
\text { por abrir } \\
\text { varios fardos. } \\
\text { simultáneamente. }\end{array}$ & $\begin{array}{l}\text { Los fardos } 363,364 \text { (parcial) y } 23 \text { fueron } \\
\text { abiertos juntos en } 1967 \text {. Aparentemente se } \\
\text { perdió la asociación entre el numero original } \\
\text { y el fardo, y dos fardos fueron designados } \\
\text { "23" y "23A". }\end{array}$ \\
\hline $\begin{array}{l}\text { Wari Kayan } \\
382\end{array}$ & $12 / 7137$ & $\begin{array}{l}\text { Fardo } 12 \\
(1933)\end{array}$ & & $\begin{array}{l}\text { Se alteró el } \\
\text { número para } \\
\text { cambiarlo con el } \\
\text { fardo de WK } 12 .\end{array}$ & $\begin{array}{l}\text { Anotación por Toribio Mejía en su copia } \\
\text { del protocolo de apertura y en el inventario } \\
\text { de campo. Los objetos exteriores al fardo } \\
\text { se mantuvieron con los datos de tumba e } \\
\text { inventario originales. }\end{array}$ \\
\hline
\end{tabular}



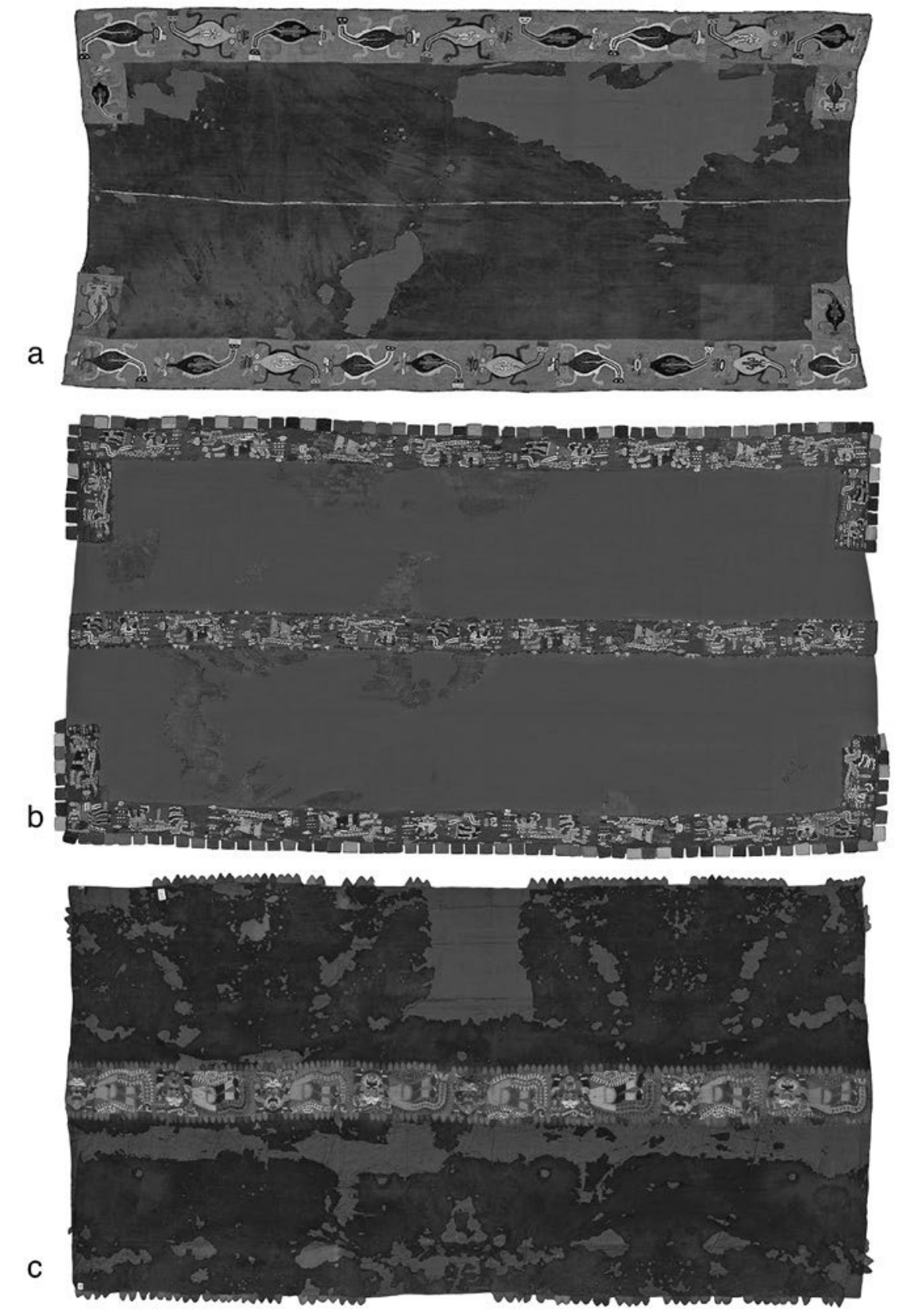

Figura 7. Formas de manto presentes en contextos de la fase 1 (A. H. Peters): a. Manto 3a, WK 217 espécimen 18 (basado en foto del proyecto Telefónica, MNAAHP). b. Manto 3b, WK 38 espécimen 37 (basado en foto del proyecto Telefónica, MNAAHP). c. Manto 3c, WK 451 espécimen 28 (basado en foto del proyecto Telefónica, MNAAHP). 
a

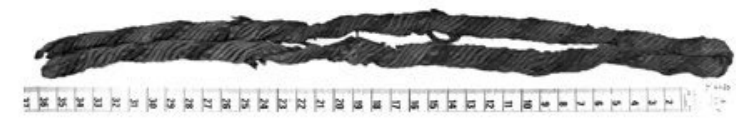

b

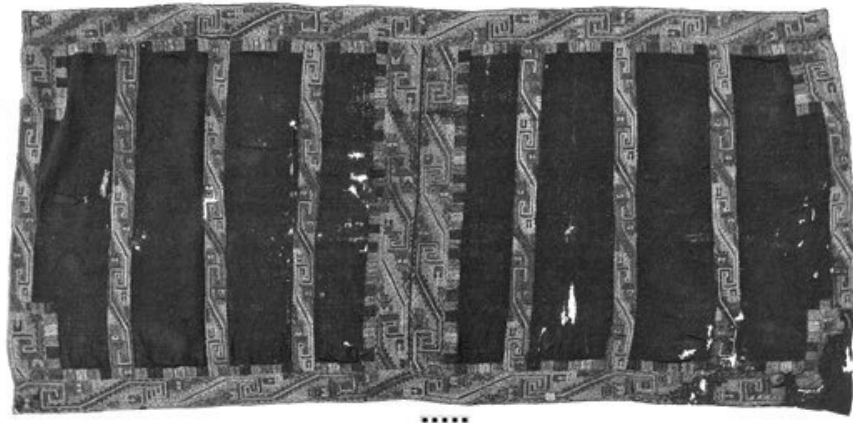

$\cdots$
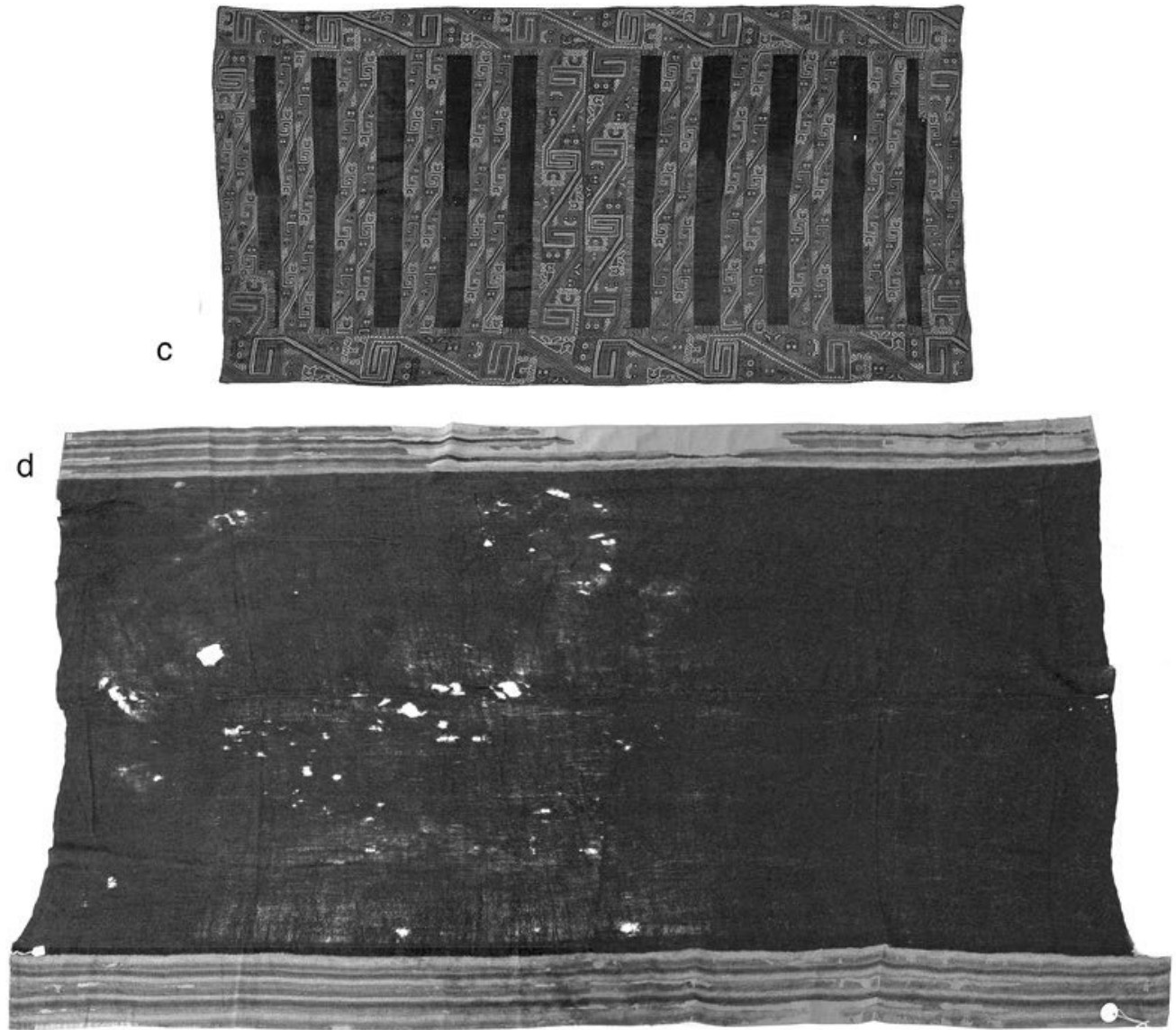

Figura 8. Formas de manto, vestido y cordón policromo presentes en contextos femeninos (A. H. Peters): a. Cordón 1, WK 113 espécimen 13 (basado en foto de Peters, AMNH 2010). b. Manto 5, WK 28 espécimen 21 (basado en fotos de Peters, MNAAHP 2007). c. Manto 5, posiblemente WK 28 espécimen 4, (basado en foto del proyecto Telefónica, MNAAHP). d. Manto 4 (vestido), WK 28 espécimen 22 (basado en fotos de Peters, MNAAHP 2007). 


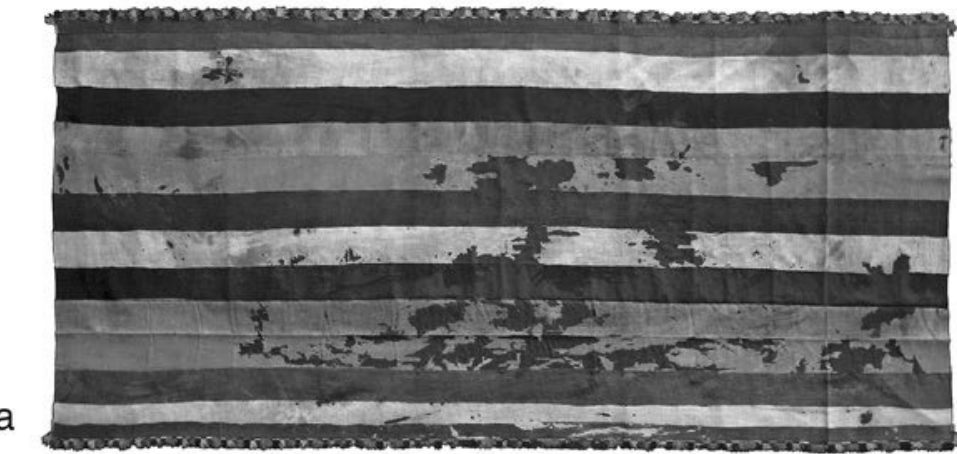

b

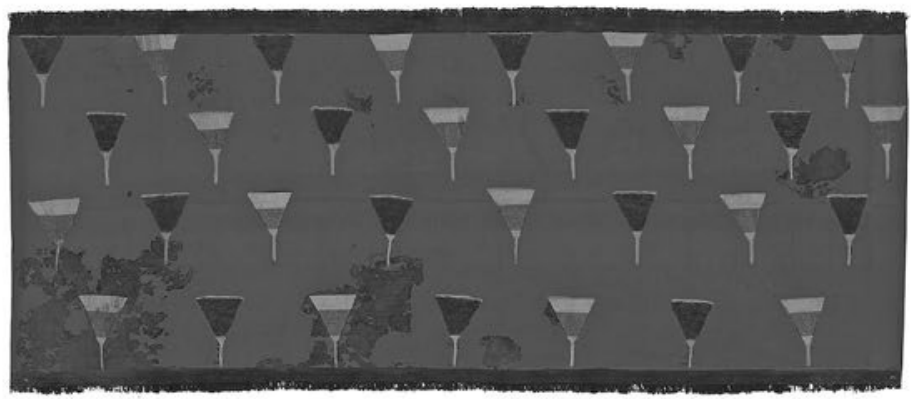

C

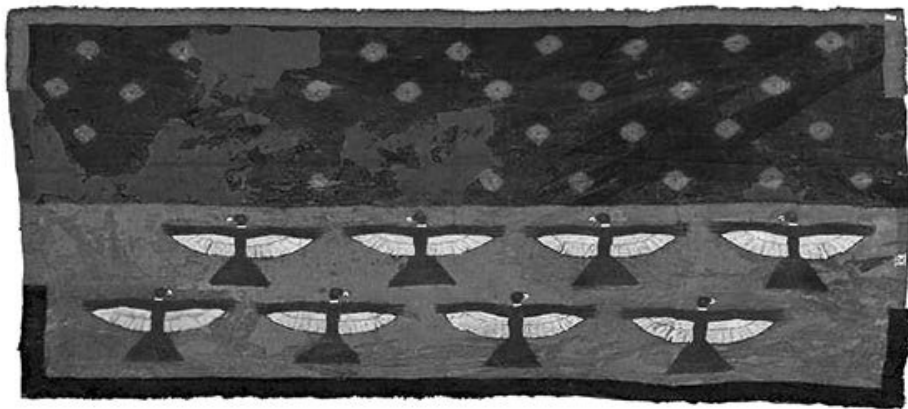

d

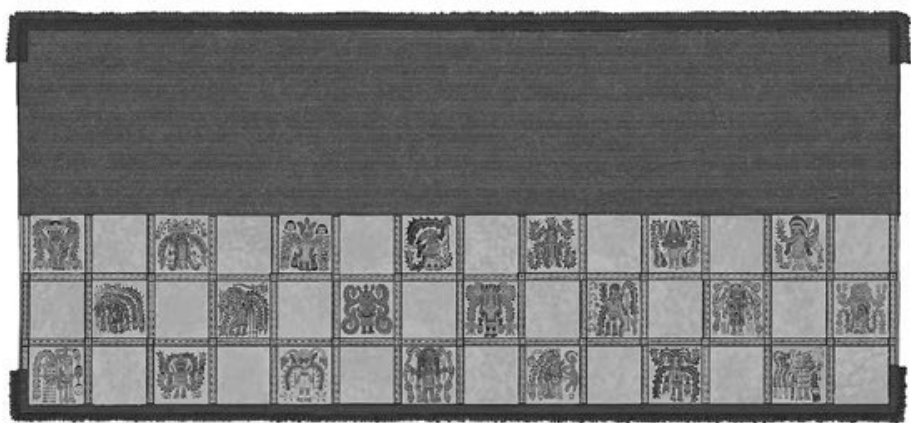

Figura 9. Formas de manto de franjas tejidas presentes en contextos masculinos de la fase 1 ( $A$. H. Peters): a. Manto 6b, WK 12 espécimen 36, reconstrucción parcial (basada en foto del proyecto Telefónica, MNAAHP). b. Manto 6a, WK 27 espécimen 8 (basado en fotos de Peters, MI-UNSAAC 2010). c. Manto 6, WK 310 espécimen 42, reconstrucción parcial (basada en foto del proyecto Telefónica, MNAAHP y dibujos de Peters, MNAAHP 1980). d. Manto 6, WK 190 (fardo 290) espécimen 45, reconstrucción por Peters (basada en diagramas en Tello 1959, láminas 68-78; Tello y Mejía 1979, 398-399, figs. 109, 110). 

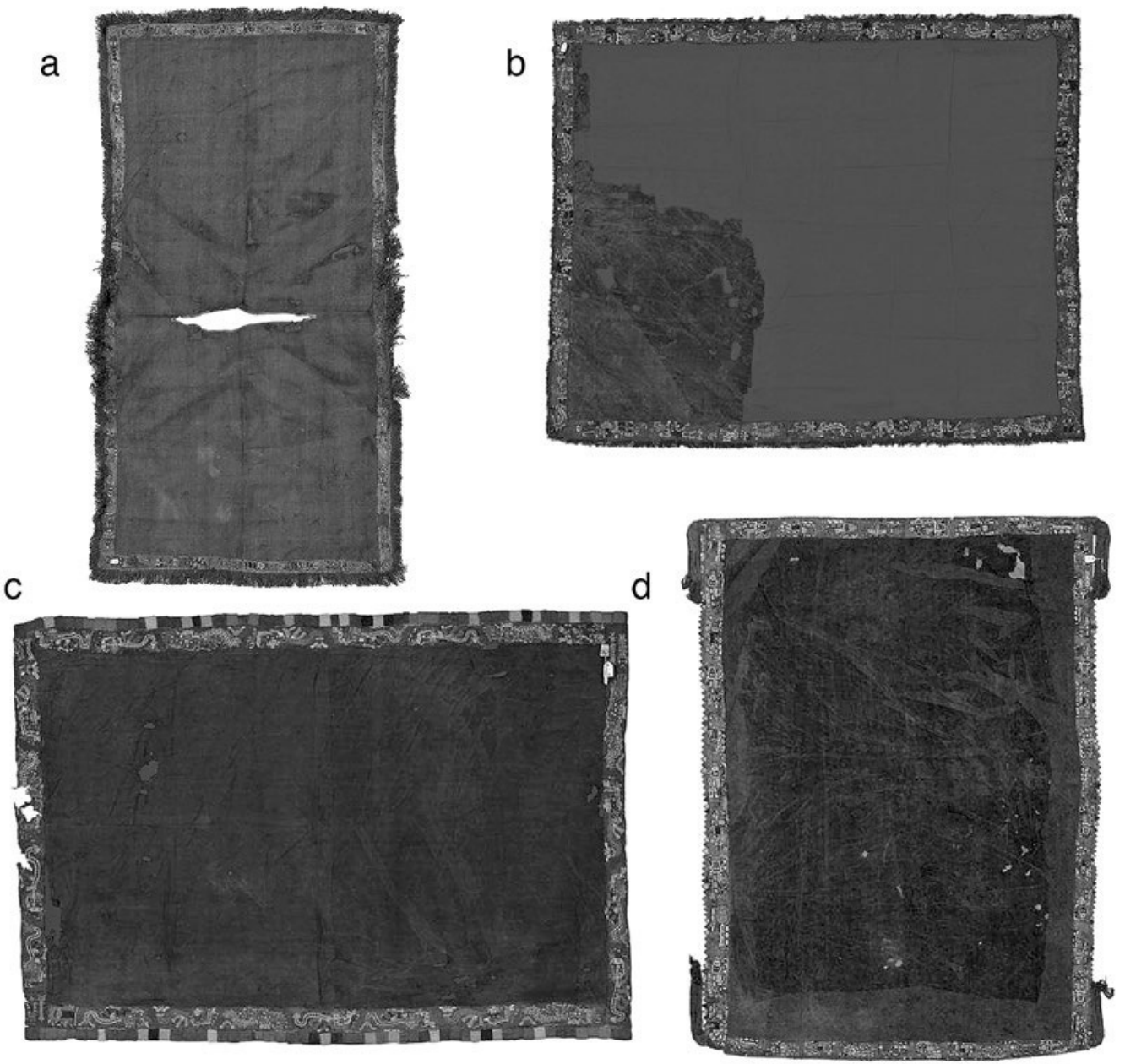

Figura 10. Formas de prendas con franjas continuas del grupo "anako", presentes en contextos masculinos de la fase $1 B$ y 2 (A. H. Peters): a. Túnica 7, WK 319 espécimen 23 (basado en foto del proyecto Telefónica, MNAAHP). $b$. Turbante 7, WK 38 espécimen 39c (basado en foto del proyecto Telefónica, MNAAHP). c. Manto 7, WK 38 espécimen 39a (basado en foto del proyecto Telefónica, MNAAHP). d. Wara 7, WK 38 espécimen 38 (basado en foto del proyecto Telefónica, MNAAHP).

En ciertos fardos masculinos de la fase $1 \mathrm{~A}$ y los fardos masculinos complejos de la fase $1 \mathrm{~B}$ aparecen formas de túnica abierta, agrupadas por Tello bajo el término de "casulla» (Tabla 11), usualmente en la capa de exposición exterior. Las formas y materiales son diversos. La casulla 1 está constituida por una faz delantera y a veces otra posterior, cuadrangulares, compuestas por paneles cosidos de piel con flecos rectangulares (Yacovleff y Muelle 1934: 104, figura 12; Tello 1959, lámina LV; Tello et al. 2012 403, 416, 513). Han estado atados en las esquinas superiores, como en los hombros de un individuo. La casulla 2 se compone de uno o dos paños de algodón con hileras de plumas cosidas a la superficie externa. En su mayoría están cubiertas por plumitas amarillas, pero el paño posterior de WK 190 (fardo 290: Tabla 12) fue cubierto por hileras de plumas de ala de cóndor (Tello 1959, lámina LV; Tello et al. 2012: 352, 459). La Casulla 3 se compone de una tela de camélido teńida de azul oscuro con una abertura horizontal en el cuello y un decorado de hileras de plumas amarillas. Algunos ejemplos incorporan un aditamento rectangular en un extremo y el ejemplo de WK 451 fue cosido a un paño de algodón con flecos rectangulares tejidos 
en el otro extremo (Tello 1959, lámina XXII). La Casulla 4 es un paño de algodón con un par de figuras pintadas, presente en el fardo WK 23 y documentado como paño delantero de la casulla con plumas de cóndor en WK 190 (fardo 290) (Tello y Mejía 1979: 389, figura 106; Tello et al. 2012: 352).

Hay una forma particular de penacho asociado a varios fardos de la fase 1B (Tabla 4), una especie de borla con una armadura cónica cubierta por hileras de plumas amarillas, con otras plumas colgantes. Una variante con plumas de halcón se asocia a AB 157 y a WK 310 y un par de borlas con plumas de loro farinoso se asocian a WK 262 (Tello 1959, lámina LV; Yacovleff 1933: 157, fig. 10). También las plumas utilizadas en los abanicos se diversifican en este grupo de fardos, apareciendo las plumas de cóndor (Vultur gryphus) y de loro (Amazona farinosa), además de plumas amarillas que probablemente han sido teñidas 5 . Las formas de los abanicos también se diversifican, con una mayor presencia del abanico 2 (Yacovleff 1933: 153, fig. 7).

Los adornos de tocado proliferan en los fardos y aparece una gama de nuevas formas (Tablas 8 y 9). En los llautus en entrelazado diagonal (Bandas 4c y 4d) los hilos agrupados dominan la superficie y se crean imágenes diversas: por ejemplo, una gruesa cuerda retorcida polícroma, un trenzado, una cadena de serpientes (WK 38) o una serie de bandas con flecos (WK 451). Aparecen llautus tejidos en tapiz ranurado con figuras de guerreros y otros íconos clásicos. Finalmente, se desarrolla una gran variedad de cuerdas y cintas delgadas incorporando fibras vegetales naturales y de camélido policromas en diversas estructuras. Como en el caso de los adornos de cabello humano que caracterizan estos mismos contextos (Tabla 3), hay una forma particular que recurre en cada fardo masculino complejo, luciendo técnicas particulares que no aparecen en los otros contemporáneos.

Las formas de la indumentaria masculina también se diversifican (Tablas 5, 6 y 7). El manto 3 b lleva una banda tejida y bordada entre los dos paños de la tela central (Figura 7), además de las bandas bordadas de las franjas laterales, o solamente una flecadura en su lugar (manto 3c). Las variantes del Manto 6 de franjas tejidas (Figura 9) aparecen inicialmente en ciertos fardos de la fase 1A. En la fase 1B por lo menos un manto de este tipo está presente en cada fardo masculino complejo, con formas más variadas que incluyen una tela central compuesta por bandas en colores contrastantes. Suelen llevar bordados en hilado grueso con colores que imitan los colores del objeto representado, además de técnicas atípicas como el tejido de amarre o planghi en un manto de WK 310, o las figuras pintadas en un manto de WK 190 (fardo 290).

La Túnica 5 (unkuña) predomina y las formas varían en sus proporciones, en el ancho de las franjas, en las flecaduras presentes y en los colores predominantes (Figuras 3d y 3e). Las faldas incorporan cambios análogos a los mantos y túnicas con los cuales forman juegos de vestimenta, por ejemplo, llevando una flecadura de bandas tejidas y bordadas. Aparece la wara 3, que lleva una franja en cada extremo y tiras cosidas a los márgenes laterales (Figura 5d). Las telas de tocado son menos largas (turbante 3) y llevan franjas en todos los estilos de bordado, anillado y flecadura, con frecuencia haciendo un juego con otras prendas. Otra forma de tela de tocado es larga y más angosta (turbante 4), con franjas anchas parecidas a las de un manto que se aproximan a las dimensiones de la tela central. El turbante 5, que caracteriza el fardo WK 89, se dobla en un triángulo (Paul 1991). El turbante 6 se asemeja a un manto femenino en sus proporciones, franjas y bandas transversales bordadas en estilo lineal o línea-ancha, pero su tela fina de baja densidad, los flecos en el ruedo y otros detalles demuestran que se trata de una imitación de los estilos antiguos. Esta diversificación en las formas de las túnicas, waras y telas de tocado, demuestra las variadas identidades sociales masculinas que se hacían presentes al ofrendar estas prendas en los ritos mortuorios.

Entre los bordados domina el estilo bloc-color. En el diseño, los colores y la iconografía de los bordados lineales también se notan las influencias del estilo bloc-color. Las franjas seccionadas incluyen un estilo con secciones rectangulares en cinco o más colores diferentes y secciones trapezoidales de márgenes escalonados (Figura 3e). Los tipos de flecadura también son muy variables. 
Aparecen flecos retorcidos cortos y largos, monocromos y policromos, coordinados con los colores variables del fondo de las franjas. También en la fase $1 \mathrm{~B}$ aparecen los flecos anillados en forma triangular y trapezoidal y además guardillas interiores que imitan estos flecos.

En ciertos fardos asociados a las fases 1B y 2 aparece un grupo de vestimentas con franjas en los cuatro márgenes, denominadas por Tello y sus colegas «anako» (Figura 10). Varios ejemplares también llamados «mantón» (manto 7), se asemejan a un manto del mismo ancho que los mantos masculinos, pero no tan largo, con flecaduras diferentes en los márgenes laterales y en los extremos. Algunos ejemplares (turbante 7) tienen la tela central fina y de baja densidad que caracteriza una tela de tocado y pueden llevar adornos de largos flecos hilados en las cuatro esquinas. Otros ejemplares tienen tiras en entrelazado diagonal en las cuatro esquinas, considerados por Frame (2007) una especie de wara, similar a los de Nasca descritos por O'Neale (1937). Suelen llevar franjas de fondo color púrpura y flecos monocromos retorcidos, o flecos anillados. En WK 319 hay una túnica (túnica 7) de proporciones atípicas, con franjas continuas en los cuatro márgenes, y bordados y flecos parecidos al grupo anako. Entonces, se propone que este grupo no constituye una forma de prenda, sino que representa la tradición de vestimenta de un grupo social ligado al mundo Nasca, que llega a participar en la tradición mortuoria de Paracas Necropolis (Peters 2017b).

Lo que se aprende de las comparaciones entre el contenido de los fardos de las fases 1 y 2, es reconocer la presencia de muchos productores diferentes, marcada por múltiples estilos que pueden ser emblemáticos de un grupo social y además por estilos que pueden marcar la mano de un maestro individual. Por ejemplo, las formas de los penachos plumarios o de los adornos de cabello humano bien pueden constar la presencia de varios especialistas rituales presentes en cada generación. Entre los estilos de prendas bordadas, las diferencias a nivel de proporciones, diseńo, color y detalles de producción indican el aporte de diferentes grupos sociales. Se puede trazar la reinterpretación de un mismo ícono en estilos que varían de un fardo a otro, lo que sugiere procesos de reinterpretación con autoridad ritual. Ciertos grupos de vestimenta, como las variantes del manto 6 y el grupo anako, parecen proceder de un grupo social particular que mantiene una relación durante varias generaciones con la tradición mortuoria Paracas Necrópolis, pero cuyos productores manejan distintas normas de diseño y producción textil.

Estilos netamente Nasca aparecen en ciertos mantos y telas de tocado atípicas que han sido incorporados en cada fardo (Peters 2017b). En los fardos de la fase 2, los llautus, cintas diversas y telas de tocado de colores brillantes tienen una estrecha relación con estilos de la cuenca de Nasca, y han sido colocados en posiciones prominentes en la cima del fardo, en vez de estar tapados por prendas de los estilos que caracterizan las fases anteriores, como sucedía en la fase 1A. Este cambio de prácticas indica que el fardo ancestral ha cambiado de identidad cultural, lo que implica un realineamiento en las relaciones políticas y cambio del balance de poder en las alianzas.

La diversidad de estilos sugiere que la temporalidad representada por estos fardos puede ser mayor de lo que ha sido propuesto anteriormente. El auge de poder representado por el gran tamaño de ciertos fardos de la transición Paracas-Nasca ha sido asociado a enormes cantidades de ofrendas, entre cincuenta y más de doscientos artículos de vestimenta en los estilos de esa época; pero la evolución estilística en las fases $10 \mathrm{~A}, 10 \mathrm{~B}$ y $1 \mathrm{~A}$ sugiere que no representan más de cinco generaciones. En cambio, los fardos asociados a las fases $1 \mathrm{~B}$ y 2 incluyen entre 10 y 50 artículos de vestimenta, con una creciente presencia del grupo anako. Los grandes mantos y elementos de tocado se agrupan en ciertos estilos que caracterizan cada fardo, mientras otros mantos y telas de tocado en estilos ajenos, parecen proceder de grupos sociales a los cuales aún no se les han estudiado sus fardos ancestrales. Los objetos rituales de iconografía compleja que definen Nasca 2 probablemente han sido creados y utilizados contemporáneamente con artefactos clasificados como Nasca 1 y Nasca 3, una propuesta que ha sido desarrollada también por Carmichael (2015) a partir del análisis formal de un grupo de antaras sin procedencia arqueológica. 


\section{Continuidad e innovación en la iconografía}

Una vez establecida la tipología y secuencia de formas de indumentaria y sus estilos decorativos, se puede trazar sus asociaciones iconográficas. Aunque a primera vista lo que más impresiona es la transformación en las imágenes bordadas en los textiles, cuando se trazan los íconos independientemente del estilo de su representación, resalta más bien la continuidad. Como ha sido comentado por Yacovleff y Muelle (1934) y por Paul $(1982,1986)$, los mismos íconos se representan en los estilos lineal, línea-ancha y bloc-color. Los motivos que constituyen las figuras simples también componen las figuras complejas (Peters 1991).

Con antecedentes en la tradición Paracas, el ave-insecto dorsal, los monos-humanos, el felino lateral con manchas corporales, el ave de dos cabezas y el personaje de dos apéndices cefálicos, se pueden trazar como íconos centrales y recurrentes en todos los estilos desde el inicio hasta el final, lo que sugiere su centralidad a la identidad social e ideología de la entidad sociopolítica, asociado a las prácticas mortuorias que han creado este cementerio. La centralidad de la figura danzante o sacrificada y su coincidencia temporal con las Necrópolis de Wari Kayan, sugiere que se trata de una representación del concepto central de la mortalidad (Frame 2001) y el rol social postmortem, asociado específicamente a la tradición mortuoria de Paracas Necrópolis.

Las figuras de guerreros, cóndores, halcones y serpientes de dos cabezas aparecen desde el inicio, pero realizados en estilos de tejer y bordar que se asemejan a los textiles depositados en las tumbas de Ocucaje, y en formas que se asemejan a las figuras representadas en cerámica de los estilos Cavernas y Ocucaje 10. Los íconos relacionados a la pesca y caza marina y la producción agrícola aparecen inicialmente en la cerámica Topará, pero las figuras míticas asociadas a esos temas, en especial el "pez con brazo humano", aparecen por primera vez en los textiles de la fase $10 \mathrm{~B}$ y en ciertas vasijas cerámicas de Ocucaje 10B. Los íconos referentes al lobo marino, la llama y la vicuńa, las plantas alimenticias, diversas especies de aves, las flores y los insectos aparecen junto al estilo bloc-color y especialmente en artefactos con otras características que para cada fase son novedosas, y ligados a los estilos que se denominan Nasca.

Como los íconos y estilos de representación novedosos han sido integrados inmediatamente a los estilos de producción que dominan en el componente textil de cada fase, evidentemente ciertos elementos ideológicos asociados se incorporaban también a la autodefinición del liderazgo social en las comunidades que creaban el cementerio. Pero se mantenía un grado de independencia de la esfera política de Cahuachi, indicada por diferencias en la iconografía, las pautas de su representación y por la ausencia de las formas de cerámica decorada que definen la tradición Nasca.

\section{Cultura material, grupos sociales y proceso histórico}

La creación de una tipología formal, independiente de las denominaciones de fase temporal, nos ha permitido volver a evaluar la secuencia de formación de cada fardo y de su ubicación en el cementerio. Se puede definir los tipos de vestimenta, las técnicas y los estilos decorativos que caracterizan cada etapa de la creación de los contextos de la tradición mortuoria de Paracas Necrópolis, y cuales coinciden en cada fardo. Se puede definir los estilos dominantes y los artefactos atípicos. Se ha demostrado que los contextos de alto rango suelen incluir artefactos de más de una fase. La diversidad de estilos demuestra que hay varios grupos sociales presentes en cada momento histórico, y que la identidad cultural y las alianzas sociopolíticas de estos grupos cambian a través del tiempo.

La muestra estudiada hasta este momento constituye menos de la quinta parte de los fardos recuperados en forma cuasi intacta en las Necrópolis de Wari Kayan y otros sectores del sitio de Paracas. Todavía hay fardos complejos que no han sido intervenidos, o donde se ha registrado solamente materiales de su capa exterior. Seguramente en el futuro se podrá definir nuevos tipos de artefactos al estudiar los fardos mejor conservados. También será importante identificar en otros 
sitios contemporáneos evidencias de los estilos de vestimenta y los otros tipos de artefactos identificados en Paracas Necrópolis.

El enfoque en los grupos sociales, es decir, en las personas como agentes en la creación de los artefactos, en el intercambio de los mismos y en su reunión en cierto orden dentro de cada contexto mortuorio, ayuda a resolver los problemas en el análisis arqueológico creados por una organización lineal de los artefactos en fases. Se propone que cada fardo es producto de un grupo social identificado con el difunto, otros grupos sociales que contribuyen artículos de su propio estilo, y grupos más lejanos cuyos estilos aparecen más esporádicamente. Ciertas relaciones expresadas en el rito mortuorio pueden haber sido predominantemente bélicas, o sea productos de batallas rituales o procesos de conquista. A la vez, o en un momento histórico próximo, pueden expresar alianzas de parentesco. Tanto las pruebas de sangre como las alianzas de sangre suelen formar parte del establecimiento de relaciones de intercambio de productos, y de establecer y mantener el derecho de viajar por los territorios vecinos. A la vez, estas relaciones de intercambio han producido transformaciones en las costumbres que caracterizan cada grupo social involucrado.

La definición de la fase 10A corresponde en las Necrópolis de Wari Kayan a evidencias de alianza entre diversos grupos ligados a la misma tradición Topará, y también evidencias de interacción con vecinos de la tradición Paracas. La definición de la fase $10 \mathrm{~B}$ corresponde a alianzas y convivencia entre individuos y grupos sociales de las tradiciones Topará y Paracas, lo que produce vestimenta sincrética presente en los fardos de Wari Kayan y cerámica sincrética presente en las tumbas de Cavernas y Ocucaje. A la vez, aparecen objetos novedosos de estilo Nasca. Tanto en los textiles como en la cerámica, se establecen los motivos que luego, durante siglos, caracterizan la tradición Nasca.

La definición de la fase 1A corresponde en las Necrópolis de Wari Kayan a oleadas de nuevas formas de indumentaria, otros tipos de artefactos, nuevos estilos e iconografía que reflejan contacto con grupos sociales que no han estado presentes antes. Muy rápidamente se absorban estas influencias, creando fardos que expresan la nueva identidad y la red expandida de relaciones sociales, Típicamente, la vestimenta novedosa es tapada por mantos y tocados bordados en estilos, colores e iconografía que hacen referencia a los estilos anteriores de las tradiciones Topará y Paracas, y el fardo es acompañado por cerámica Topará creada en una escala reducida. La definición de la fase $1 \mathrm{~B}$ corresponde a la presencia de diversos estilos de vestimenta, todos asociados a colores e iconografía ligados a la tradición Nasca pero que no se asemejan a los ejemplares recuperados en Cahuachi, Cabildo u otros sitios del río Nasca.

La definición de la fase 2 corresponde también a diversos estilos. La vestimenta del grupo anako es similar en forma, pero no idéntica, a las prendas asociadas a contextos Nasca 3 en Cahuachi. Las figuras de la iconografía bordada representan motivos muy similares, pero no idénticos, a los que recurren en textiles y cerámica Nasca. Ciertos tocados, sin embargo, son tan similares en su color y técnica a los de la cuenca de Nasca, que deben haber sido creados por manos sureñas. La cerámica que acompaña a los fardos es escasa, monocroma y reducida a miniaturas, con formas relacionadas a los recipientes grandes de estilo Campana (Massey 1986) que aparecen en ciertas tumbas de Ocucaje.

Es importante considerar que los grupos sociales ligados a las tradiciones Topará y Paracas no dejan de existir, sino que adoptaron nuevas prácticas, íconos y estilos en la interacción con sus vecinos. Este proceso se encuentra plasmado en la adaptación de los íconos asociados a las diversas técnicas estructurales que caracteriza la tradición Paracas, a nuevos estilos de bordado, agrupados bajo el término "línea-ancha», que caracterizan la fase 10B y los fardos transicionales. Sin duda existen estilos propios de grupos descendientes de Paracas en la diversidad de estilos presentes en la fase 1 y se nota el resurgimiento de ciertas prácticas «antiguas» en las tumbas de la fase 2. Estas interacciones se trazan también en las tumbas de Ocucaje, en la dinámica propia de otro centro regional. 
¿Cómo han reproducido las prácticas mortuorias, las formas de vestir el fardo y ciertos elementos de la indumentaria, el estilo y la iconografía, a través de generaciones, durante alrededor cuatrocientos años? Al trazar los cambios en las prácticas mortuorias y evidentemente en las identidades sociales, las continuidades se hacen más llamativas. Es necesario considerar el acto de honrar y renovar el fardo del recién fallecido o del ancestro como un acto público central a la reproducción del orden social. Al decir "público»' no quisiera sugerir que no existían restricciones en quienes participaban, o en sus roles. Más bien, la autoridad ritual debe haberse establecido a través de la experiencia y el conocimiento del significado de los artefactos asociados a ciertos fardos ancestrales y de las historias incorporadas en ellos. Esta autoridad explica la reinterpretación de los mismos íconos en estilos cambiantes y también la resucitación de ciertos rasgos de estilo, en artefactos distintos en otra época.

Se trata de un rito mortuorio que convocaban personas procedentes de distintos grupos sociales, en el cual ciertos fardos deben haber sido modificados durante las ceremonias con la intervención de un mismo grupo de líderes rituales. Por ejemplo, los adornos plumarios se agrupan, tanto por sus plumas componentes como por su estructura. El guacamayo, la oropéndola, el halcón, el cóndor o el loro farinoso, aparecen en un grupo de objetos plumarios en ciertos fardos que también comparten otras características, lo que indica que su presencia pudiera marcar circunstancias históricas compartidas: por ejemplo, un viaje a larga distancia, la adaptación de un ave al contexto social humano, o la identificación de cierta especie con cierto grupo social o especialista ritual. Los maestros a cargo de los procesos de interpretación y rediseño y de la producción de un nuevo manto (Paul y Niles 1985) o conjunto de indumentaria, deben haber observado directamente ejemplos de textiles antecesores. Por eso, los indicadores de una relación cercana a nivel de diseño, iconografía y prácticas de producción son complicados. Se trata no solamente de los actores sociales contemporáneos en la vida, sino también de los personajes y conjuntos artefactuales que coexistían en una vida social postmortem.

Grupos sociales identificados con prácticas de producción, conceptos ideológicos y formas de liderazgo ligados a los artefactos que los arqueólogos definen como culturas o tradiciones denominadas Paracas, Topará y Nasca, evidentemente han coexistido en un proceso histórico de relaciones cambiantes de interacción e influencia mutua durante la creación de estos cementerios (Van Gijseghem 2006). A través del tiempo ha cambiado su relativa dominancia en el proceso sociopolítico de creación de cada fardo y en la proyección de identidades sociales en cada capa de exposición pública. Si bien el patrón mortuorio Paracas Necrópolis está ligado a entidades sociales asociadas a variantes de la tradición cerámica Topará, y la mayoría de los estilos textiles que dominan en cada fardo han sido probablemente producidos por comunidades ligadas a esa tradición, en cada fase aparecen artefactos evidentemente no producidos por ellas. El carácter de estos artefactos cambia a través del tiempo, ligado tanto a las relaciones políticas cambiantes con otras comunidades como a los cambios en los estilos emblemáticos de cada grupo social.

\section{Agradecimientos}

Se agradece a las instituciones que nos han permitido trabajar en sus colecciones y en sus archivos y en especial a los colegas que nos han proporcionado información procedente del análisis de su catalogación: en el Museo Nacional de Antropología, Arqueología e Historia del Perú, el Museo de Antropología y Arqueología de la Universidad Nacional Mayor de San Marcos, el Instituto Riva-Agüero de la Pontificia Universidad Católica del Perú, el Museo Regional de Ica Adolfo Bermúdez Jenkins, el Museo Inka de la Universidad Nacional San Antonio Abad de Cusco, el Museo Americano de Historia Natural y el Museo Peabody de Etnología y Arqueología de la Universidad de Harvard. Se agradece a los colegas arqueólogos y biólogos que han participado en la documentación de cada tipo de artefacto en los fardos estudiados y en la muestra comparativa: 
Alberto Ayarza, Luis Alberto Peña, Ana Murga, Andrés Shiguekawa, Enrique Angulo, Antje Chiu, Paul Sweet y Vanessa Tinteroff. Se agradece a los colegas bioantropólogos y médicos que han contribuido con sus conocimientos especializados: Mellisa Lund, Richard Sutter, Uriel García, Guido Lombardi, Gerald Conlogue, Pierre Sasson y Lars Fehren-Schmidt. A los estudiantes y practicantes que han colaborado con mucha paciencia en las labores de conservación y documentación, un fuerte aplauso y mi deseo de conocer sus trabajos futuros. Sobre todo, gracias a Carmen Carranza por dirigir las labores de conservación preventiva y dialogar acerca de las técnicas textiles y a Elsa Tomasto-Cagigao, bioantropóloga y codirectora del proyecto.

\section{Notas}

1 También hay ciertos contextos que parecen ser de una época anterior, como la mujer WK 70 que tiene textiles característicos de Cavernas (tentativamente fase 8), pero que han sido colocados en el cementerio de Wari Kayan, incluso en este caso encima de fardos más tardíos.

2 Las imágenes no corresponden a las leyendas en esta publicación; aquí se hace referencia a la imagen.

3 Desrosiers propone que el origen del estilo Lineal se puede trazar hacia el diseño en la técnica de urdimbres complementarias. La relación con el diseño con urdimbres suplementarias es evidente en los extremos de ciertas franjas bordadas donde se imitan los grupos de urdimbres de colores contrastantes.

4 Para otras pautas de comparación entre textiles de Paracas Necrópolis y textiles de Nasca temprano, ver Sawyer 1997 y Silverman 2002.

5 Las identificaciones de especie realizadas por Enrique Angulo, Antje Chiu y Paul Sweet indican aves que habitan zonas lacustres o marinas, las que incluyen la garza (Egretta thula) y la pariguana (Phoenicopterus chilensis). Sweet ha identificado el uso de tinte para obtener el color amarillo en el abanico de WK 114.

\section{REFERENCIAS}

Aponte, D.

2006 Presentación de los materiales del fardo funerario 290 de Wari Kayán, Paracas Necrópolis. Arqueológicas 27: 9-99.

Bird, J. B. y L. C. Bellinger

1954 Paracas fabrics and Nazca needlework: 3rd century B.C.-3rd century A.D, The Textile Museum, Catalogue Raisonné, National Publishing Company, Washington, DC.

Buikstra, J. E. y D. Ubelaker

1994 Standards for data collection from human skeletal remains, Arkansas Archaeological Survey Research Series 44, Fayetteville.

Carmichael, $\mathrm{P}$.

2015 Proto-Nasca art and antaras, Nawpa Pacha 35(2),117-172. https://doi.org/10.1080/00776297.2015.11 08122

DeLeonardis, L. y G. F. Lau

2004 Life, death and ancestors, en: H. Silverman (ed.), Andean Archaeology, 77-115, Blackwell, New York.

Desrosiers, $S$.

2008 Revisiting the Ocucaje opened tunic from the textile museum, Textile models and the process of imitation, The Textile Society of America Symposium Proceedings, Paper 89, Washington, D.C. http://digitalcommons.unl.edu/tsaconf/89 
Duviols, P.

2003 Procesos y visitas de idolatrias. Cajatambo, siglo XVII, Fondo Editorial PUCP/Instituto Francés de Estudios Andinos, Lima.

Dwyer, J. P.

1979 The Chronology and Iconography of Paracas-style Textiles. In: The Junius B. Bird Pre-Columbian Textile Conference, Anne Pollard Rowe, Elizabeth B. Benson y Anne-Louise Schaffer (eds.): 105-128; Washington, DC: Textile Museum y Dumbarton Oaks.

Emery, I.

1994 The primary structures of fabrics: An illustrated classification, 2da edición, The [1980, 1966] Textile Museum Washington, D.C.

\section{Frame, $M$.}

1991 Structure, image and abstraction: Paracas Necrópolis Headbands as system templates, en: A. Paul (ed.), Paracas art and architecture: Object and context in south coastal Peru, 110-171, University of Iowa Press, Iowa City.

1999 Textiles de estilo Nasca, en: J. A. de Lavalle y R. de Lavalle de Cárdenas (eds.), Tejidos milenarios del Perúl Ancient Peruvian textiles, 261-310, AFP Integra, Lima.

2001 Blood, fertility and transformation: Interwoven themes in the Paracas Necropolis embroideries, en: E. P. Benson y A. G. Cook (eds.), Ritual sacrifice in ancient Peru: New discoveries and interpretations, 55-92, Dumbarton Oaks. Washington, D.C.

2007 Las prendas bordadas de la necrópolis de Wari Kayan, en: E. León (ed.), Hilos del pasado: el aporte francés al legado de Paracas, 65-73, Instituto Nacional de Cultura, Lima.

2009 Los textiles de Cahuachi, en: G. Orefici (ed.), Nasca: el desierto de los dioses de Cahuachi, 188-211, Centro Italiano Studi e Ricerche Archeologiche Precolombiani, Lima.

Gell, A.

1998 Art and agency, Oxford University Press, London/New York.

Godelier, M.

1998 El enigma del don, Ediciones Paidos, Madrid.

[1996]

Hoces De La Guardia, M. S. y P. Brugnoli

2006 Manual de técnicas textiles andinas: Terminaciones. Santiago: Consejo Nacional de la Cultura y de las Artes y Museo Chileno de Arte Precolombino.

Isbell, W.

1997 Mummies and mortuary monuments: A Postprocessual prehistory of central Andean social organization, University of Texas Press, Austin.

Kauffman D., F.

1999 El arte textil de Paracas, en: J. A. de Lavalle y R. de Lavalle de Cárdenas (eds.), Tejidos milenarios del Perúl Ancient Peruvian textiles, 143-234, AFP Integra, Lima.

King, M. E.

1965 Textiles and basketry of the Paracas Period, Ica Valley, Peru, tesis de doctorado, Department of Anthropology, University of Arizona.

Kroeber, A. L.

1953 Paracas Cavernas and Chavín, University of California Publications in American Archaeology and Ethnology 40(8), 313-348.

Maita, P. K. y E. Minaya

2014 El trauma en la piel: un análisis paleopatológico de tatuajes Paracas-Necrópolis, Revista Jangua Pana 13, 14-33. https://doi.org/10.21676/16574923.1369

Massey, S.

1986 Sociopolitical change in the upper Ica Valley, BC 400 to 400 AD: Regional states on the south coast of Peru, tesis de doctorado, Department of Anthropology, University of California Los Angeles, Los Angeles. 
Mauss, M.

1990 The gift: The form and reason for exchange in archaic societies, [traducción de W.

[1923-24] D. Halls], W. W. Norton, New York/London.

Medina, M. Y.

2009 Pervivencia de la función y tecnología en los llautus: de Cavernas hacia Wari Kayan, Paracas Cavernas. Cuaderno de Investigación del Archivo Tello. 7, 11-15, Museo de Arqueología y Antropología, Universidad Nacional Mayor de San Marcos, Lima.

Menzel, D., J. H. Rowe y L. E. Dawson

1964 The Paracas pottery of Ica: A study in style and time, University of California Publications in American Archaeology and Ethnology 50, University of California, Berkeley.

Museo Nacional de Antropología, Arqueología e Historia del Perú http://museonacional.perucultural.org.pe/ colecciones.htm; consultado en línea.

O'neale, L. M.

1932 Tejidos del período primitivo de Paracas, Revista del Museo Nacional 1(2), 60-80.

1937 Archaeological explorations in Peru, Part III. Textiles of the Early Nazca Period, Field Museum of Natural History, Anthropology, Memoirs 2(3), 118-253.

1942 Textile periods in ancient Peru: II. Paracas Cavernas and the Grand Necropolis, University of California Publications in American Archaeology and Ethnology 39(2), 143-202.

Orefici, G. y A. Drusini

2003 Nasca. Hipótesis y evidencias de su desarrollo cultural, Centro Italiano Studi e Ricerche Archeologiche Precolombiane, Lima.

Paul, A.

1982 The chronological relationship of the linear, block color and broad line styles of Paracas embroidered images, en: A. Cordy-Collins (ed.), Pre-Columbian art history: Selected readings, 255-277, Peek Publications, Palo Alto.

1986 Continuity in Paracas textile iconography and its implications for the meaning of linear style images, en: A. P. Rowe (ed.), The Junius B. Bird Conference on Andean Textiles, April 7th and 8th, 1984, 81-99, The Textile Museum, Washington, D.C.

1990 Paracas ritual attire: Symbols of authority in ancient Peru, University of Oklahoma Press, Norman.

1991 Paracas Necropolis Burial 89, en: A. Paul (ed.), Paracas Art and Architecture: Object and Context in South Coastal Peru, 171-221, University of Iowa Press, Iowa City.

Paul, A. y S. A. Niles

1985 Identifying hands at work on a Paracas Mantle, Textile Museum Journal 23, 5-15.

Paul, A. y S. Turpin

1986 The ecstatic shaman theme of Paracas textiles, Archaeology 39(5), 20-27.

Peters, A. H.

1997 Paracas, Topará and Early Nasca: Ethnicity and society on the south central Andean coast, tesis de doctorado, Department of Anthropology, Cornell University.

2011 Diversidad en el componente textil y modelos de las relaciones sociales: un ejemplo de Paracas Necrópolis, Actas de los V Jornadas Internacionales sobre Textiles Precolombinos (29 Noviembre-1 Diciembre, 2010), 231-256; Centre D’Estudis Precolombins, Barcelona.

2014 Paracas Necropolis: Communities of textile production, exchange networks and social boundaries in the central Andes, 150 BC to AD 250, en: D. Arnold y P. Dransart (eds.), Textiles, techne and power, 109-139, Archetype, London.

2017a Headdress forms in the Paracas Necrópolis mortuary tradition, en: L. Bjerregaard y A. H. Peters (eds.), Pre-Columbian Textile Conference VII/ Jornadas de Textiles Precolombinos VII, Centre for Textile Research, University of Copenhagen, 214-237, Zea Books, Lincoln. https://doi.org/10.13014/K2FT8J75

2017b El testimonio de una tumba: la presencia Nasca en Paracas; Fardo WK 382, Fardo WK 378 y Fardo WK 319, Anexo: Paracas y Nasca en Wari Kayan, en: C. Pardo y P. Fux, (eds.): Nasca, 62-69; 292-299; Museo de Arte de Lima/Museum Reitburg, Lima. 
Peters, A. y E. Tomasto-Cagigao

2017 Masculinities and femininities: Forms and expressions of power in the Paracas Necropolis, en: S. Scher y B. J. A. Follensbee (eds.), Dressing the part: Power, dress, gender, and representation in the pre-Columbian Americas, 371-449, University Press of Florida, Gainesville.

Proulx, D. A.

1968 Local differences and time differences in Nasca pottery, University of California Publications in Anthropology 5, University of California Press, Berkeley/Los Angeles.

2006 A sourcebook of Nasca ceramic iconography: Reading a culture through its art, University of Iowa Press, Iowa City.

\section{Rostworowski, M.}

1983 Estructuras andinas de poder, Instituto de Estudios Peruanos, Lima.

Rowe, A. P.

2015 The linear mode revisited, Nawpa Pacha 35(2), 237-258. https://doi.org/10.1080/00776297.2015.110 8126

Sackett, J.

1990 Style and ethnicity in archaeology: The case for isocrestism, en: M Conkey y C. Hastorf (eds.), The uses of style in archaeology, 32-43, Cambridge University Press, Cambridge.

Sawyer, A.

1961 Paracas and Nazca iconography, en: S. Lothrop (ed.), Essays in pre-Columbian art and archaeology, Harvard University Press, Cambridge.

1979 Painted Nasca textiles, en: A. P. Rowe, E. B. Benson y A-L Schaffer (eds.), The Junius B. Bird pre-Columbian textile conference, 129-150, Textile Museum and Dumbarton Oaks, Washington, D.C.

1997 Early Nasca needlework, Laurence King Publishing/Primitive Arts Ltd., London.

Silverman, $\mathrm{H}$.

2002 Differentiating Paracas Necrópolis and Early Nazca textiles, en: W. H. Isbell y H. Silverman (eds.): Andean Archaeology II: Art, landscape and society, 71-105, Kluwer Academic/ Plenum Publishers, New York. https://doi.org/10.1007/978-1-4615-0597-6_4

Tello, J. C.

1929 Antiguo Perú: primera época, Comisión Organizadora del Segundo Congreso Sudamericano de Turismo, Lima.

1930 Andean civilization: some problems of Peruvian Archaeology, Proceedings of the XXIII International Congress of Americanists (New York, September 17-22, 1928), 259-290.

1959 Paracas: primera parte, Institute of Andean Research, Lima.

2012 Wari Kayan, Cuaderno del Archivo Tello 9, Museo de Arqueología y Antropología, Universidad Nacional Mayor de San Marcos, Lima.

Tello, J. C. y T. Mejía

1979 Paracas, segunda parte: Cavernas y Necrópolis, Universidad Nacional Mayor de San Marcos/Institute of Andean Research, Lima.

Thays, C.

2016 Reproducción del ritual funerario: preparación del cuerpo, orden y distribución de las ofrendas, Arqueológicas 30, 69-86.

Tomasto-Cagigao, E., A. Peters, M. Lund y A. Ayarza

2013 Body modification at Paracas Necropolis (South Coast of Peru ca. 2000 BP), en: P. Della Casa y C. Witt (eds), Tattoos and Body Modifications in Antiquity. Proceedings of the sessions at the EAA annual meetings in The Hague and Oslo, 2010-11, Zurich Studies in Archaeology 9, 49-58.

Uhle, $M$.

1914 The Nazca pottery of ancient Peru, Proceedings of the Davenport Academy of Sciences 13, 1-15.

\section{Van Gijseghem, H.}

2006 A frontier perspective on Paracas society and Nasca ethnogenesis, Latin American Antiquity 17(4), 419-444. https://doi.org/10.2307/25063066 
Wallace, D.

1986 The Topará Tradition: An overview, en: D. H. Sandweiss y P. Kvietok (eds.), Perspectives on Andean prehistory and protohistory: Papers from the third Annual Northeast Conference on Andean Archaeology and Ethnohistory, 35-62, Latin American Studies Program, Cornell University, Ithaca.

Wobst, M.

1977 Stylistic behavior and information exchange, en: C. E. Clelland (ed.), For the director: Research essays in honor of James B. Griffin, Anthropological Paper 61, 317-42, Museum of Anthropology/University of Michigan, Ann Arbor.

Yacovleff, E.

1933 Arte plumaria entre los antiguos peruanos, Revista del Museo Nacional 2(2), 137-158.

Yacovleff, E. y J. C. Muelle

1934 Un fardo funerario de Paracas, Revista del Museo Nacional 3(1-2), 63-153.

Zuidema, R. T.

1990 Dynastic structures in Andean culture, en: M. Moseley y A. Cordy-Collins (eds.), The northern dynasties: Kingship and statecraft in Chimor, 489-505, Dumbarton Oaks, Washington, D.C.

Recepción: 4/VI/2018

Aceptación: 17/VII/2018 